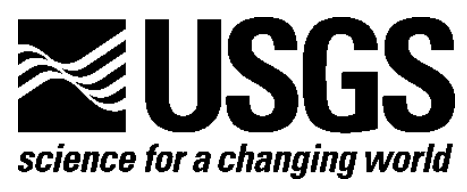

\title{
Sediment-Hosted Zinc-Lead Deposits of the World- Database and Grade and Tonnage Models
}

By Donald A. Singer ${ }^{1}$, Vladimir I. Berger ${ }^{1}$, and Barry C. Moring ${ }^{1}$

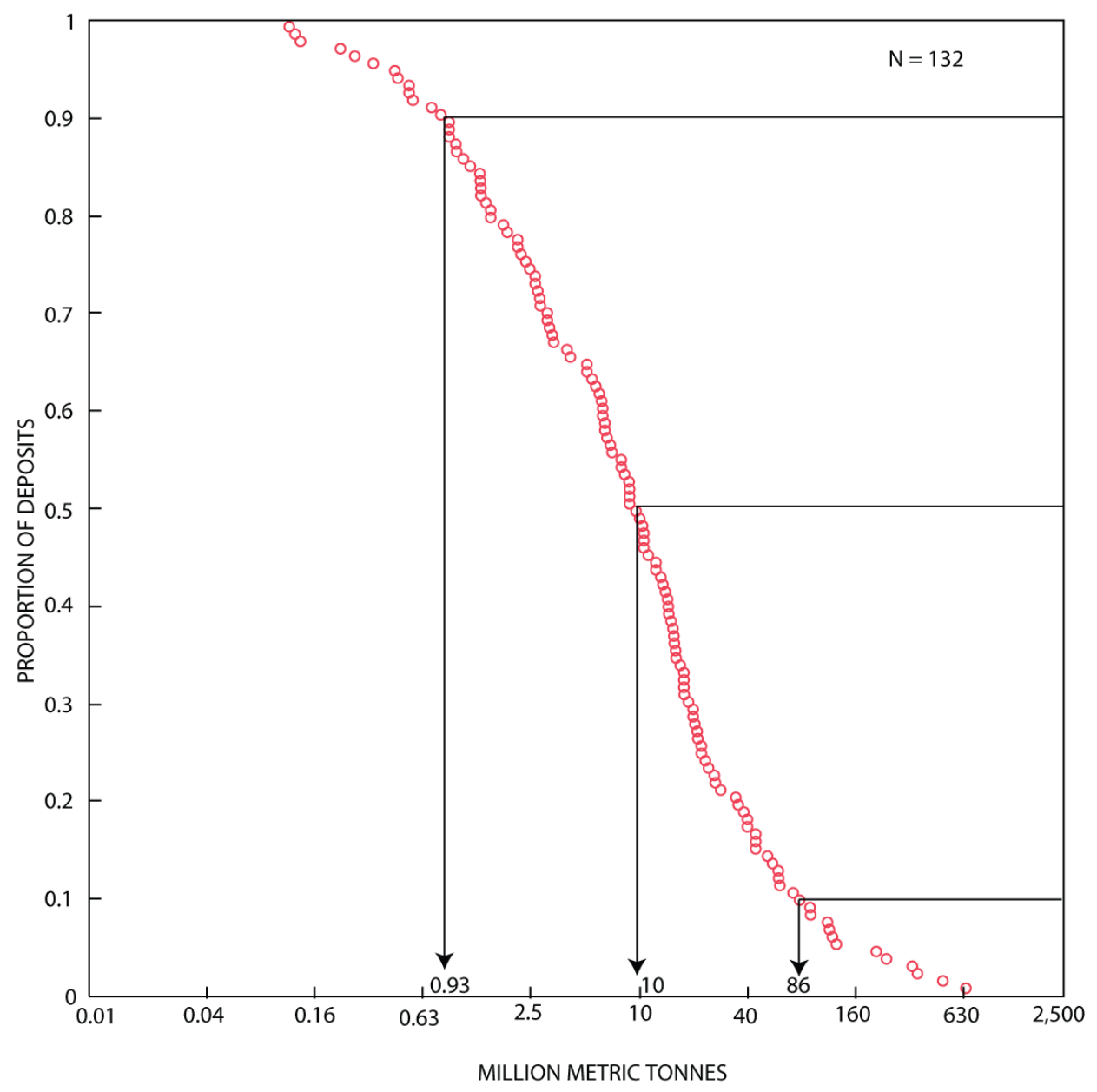

Open-File Report 2009-1252

1U.S. Geological Survey, Menlo Park, Calif.

U.S. Department of the Interior

U.S. Geological Survey 


\section{U.S. Department of the Interior KEN SALAZAR, Secretary}

\section{U.S. Geological Survey Marcia K. McNutt Director}

U.S. Geological Survey, Reston, Virginia 2009

For product and ordering information:

World Wide Web: http://www.usgs.gov/pubprod

Telephone: 1-888-ASK-USGS

For more information on the USGS—-the Federal source for science about the Earth, its natural and living resources, natural hazards, and the environment:

World Wide Web: http://www.usgs.gov

Telephone: 1-888-ASK-USGS

Suggested citation:

Singer, D.A., Berger, V.I., and Moring, B.C., 2009, Sediment-hosted zinc-lead deposits of the world; database and grade and tonnage models: U.S. Geological Survey Open-File Report 2009-1252, http://pubs.usgs.gov/of/2009/1252/

Any use of trade, product, or firm names is for descriptive purposes only and does not imply endorsement by the U.S. Government.

Although this report is in the public domain, permission must be secured from the individual copyright owners to reproduce any copyrighted material contained within this report.

About the cover: Cumulative frequency of ore tonnage of carbonate-hosted amagmatic zinc-lead (CAam) deposits. Each circle represents an individual deposit. Intercepts for the 90th, 50th, and 10th percentiles of the observed distribution are provided (from fig. 1). 


\section{Contents}

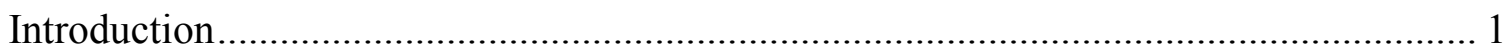

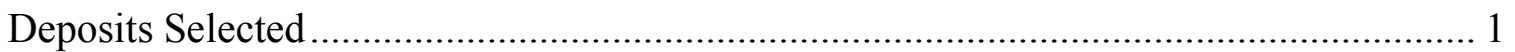

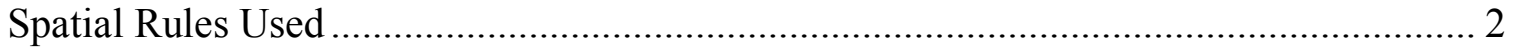

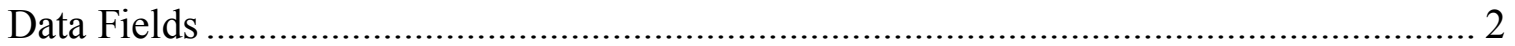

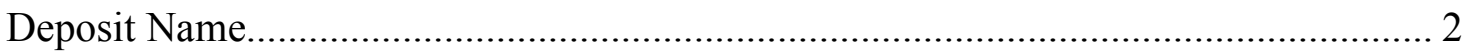

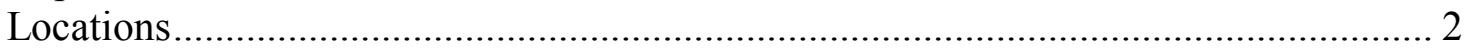

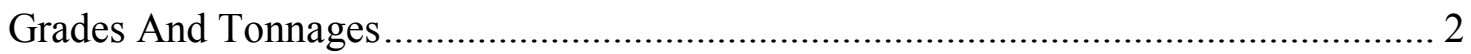

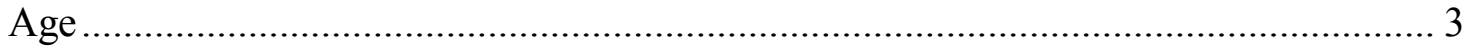

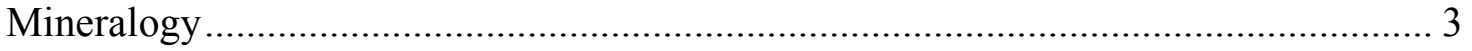

Types of Sediment-Hosted Zinc-Lead Deposits …………………………………..... 3

Size and Shape of Alteration and Ore Bodies.............................................................. 5

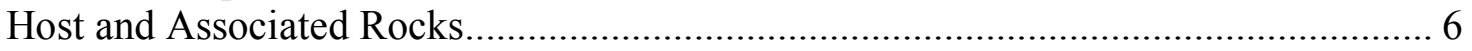

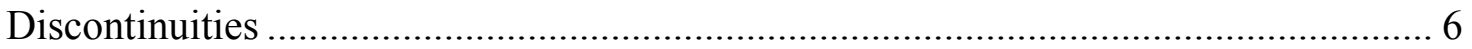

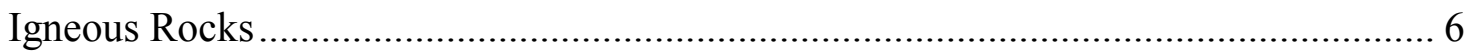

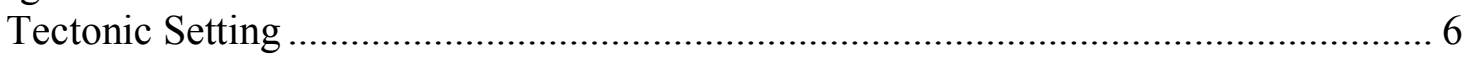

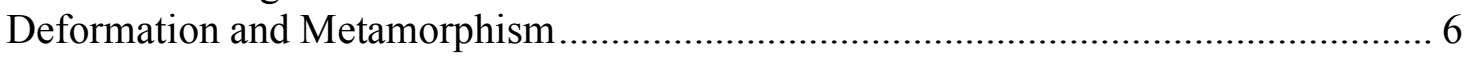

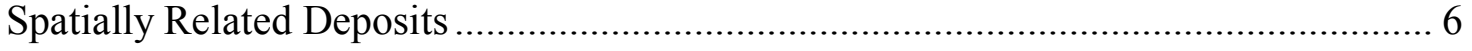

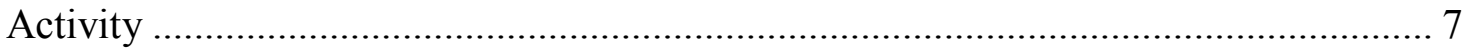

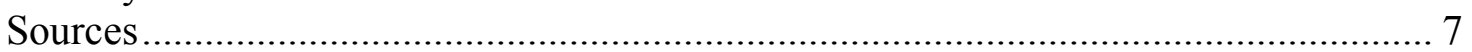

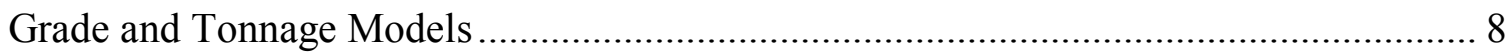

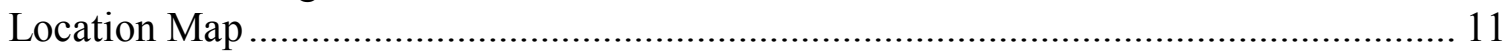

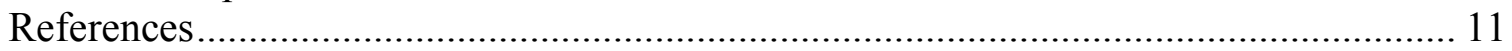

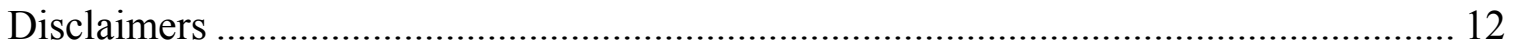

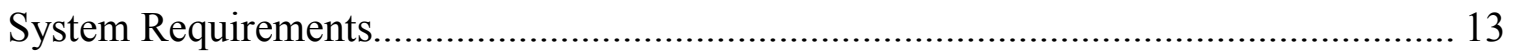

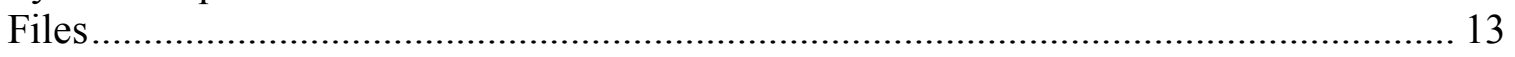

\section{Tables}

1. Names of deposit types and their associated codes used in the "OtherDeposits"

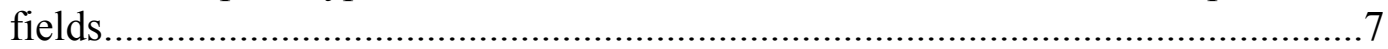

2. Grade and tonnage models of sediment-hosted $\mathrm{Zn}-\mathrm{Pb}$ deposits by type. ...............9

3. Reports of gold grades or minerals in sediment-hosted $\mathrm{Zn}-\mathrm{Pb}$ deposits by type.

\section{Figures}

1. Cumulative frequency of ore tonnage of carbonate-hosted amagmatic zinc-lead (CAam) deposits

2. Cumulative frequency of average zinc grade of carbonate-hosted amagmatic zinclead (CAam) deposits...................................................................................

3. Cumulative frequency of average lead grade of carbonate-hosted amagmatic zinclead (CAam) deposits. 
4. Cumulative frequency of average copper grade of carbonate-hosted amagmatic zinc-lead (CAam) deposits....

5. Cumulative frequency of average silver grade of carbonate-hosted amagmatic zinc-lead (CAam) deposits.

6. Cumulative frequency of average gold grade of carbonate-hosted amagmatic zinclead (CAam) deposits

7. Cumulative frequency of ore tonnage of carbonate-hosted igneous-related zinclead (CAig) deposits

8. Cumulative frequency of average zinc grade of carbonate-hosted igneous-related zinc-lead (CAig) deposits

9. Cumulative frequency of average lead grade of carbonate-hosted igneous-related zinc-lead (CAig) deposits

10. Cumulative frequency of average copper grade of carbonate-hosted igneousrelated zinc-lead (CAig) deposits.

11. Cumulative frequency of average silver grade of carbonate-hosted igneous-related zinc-lead (CAig) deposits

12. Cumulative frequency of average gold grade of carbonate-hosted igneous-related zinc-lead (CAig) deposits

13. Cumulative frequency of ore tonnage of carbonate-hosted metamorphosed zinclead (CAme) deposits.

14. Cumulative frequency of average zinc grade of carbonate-hosted metamorphosed zinc-lead (CAme) deposits.

15. Cumulative frequency of average lead grade of carbonate-hosted metamorphosed zinc-lead (CAme) deposits.

16. Cumulative frequency of average silver grade of carbonate-hosted metamorphosed zinc-lead (CAme) deposits

17. Cumulative frequency of ore tonnage of Kipushi deposits. .30

18. Cumulative frequency of average zinc grades of Kipushi deposits .......................31

19. Cumulative frequency of average lead grades of Kipushi deposits .......................32

20. Cumulative frequency of average copper grades of Kipushi deposits...................33

21. Cumulative frequency of average silver grades of Kipushi deposits.....................34

22. Cumulative frequency of ore tonnage of mixed lithology igneous-related zinc-lead (MLig) deposits.

23. Cumulative frequency of average zinc grades of mixed lithology igneous-related zinc-lead (MLig) deposits

24. Cumulative frequency of average lead grades of mixed lithology igneous-related zinc-lead (MLig) deposits

25. Cumulative frequency of average copper grades of mixed lithology igneousrelated zinc-lead (MLig) deposits

26. Cumulative frequency of average silver grades of mixed lithology igneous-related zinc-lead (MLig) deposits

27. Cumulative frequency of average gold grades of mixed lithology igneous-related zinc-lead (MLig) deposits

28. Cumulative frequency of ore tonnage of mixed lithology metamorphosed zinclead (MLme) deposits 
29. Cumulative frequency of average zinc grades of mixed lithology metamorphosed zinc-lead (MLme) deposits

30. Cumulative frequency of average lead grades of mixed lithology metamorphosed zinc-lead (MLme) deposits

31. Cumulative frequency of average copper grades of mixed lithology metamorphosed zinc-lead (MLme) deposits.

32. Cumulative frequency of average silver grades of mixed lithology metamorphosed zinc-lead (MLme) deposits.

33. Cumulative frequency of ore tonnage of shale-hosted amagmatic zinc-lead (SHam) deposits

34. Cumulative frequency of average zinc grades of shale-hosted amagmatic zinclead (SHam) deposits

35. Cumulative frequency of average lead grades of shale-hosted amagmatic zinclead (SHam) deposits

36. Cumulative frequency of average copper grades of shale-hosted amagmatic zinclead (SHam) deposits

37. Cumulative frequency of average silver grades of shale-hosted amagmatic zinclead (SHam) deposits

38. Cumulative frequency of average gold grades of shale-hosted amagmatic zinclead (SHam) deposits

39. Cumulative frequency of ore tonnage of shale-hosted igneous-related zinc-lead (SHig) deposits

40. Cumulative frequency of average zinc grades of shale-hosted igneous-related zinc-lead (SHig) deposits.

41. Cumulative frequency of average lead grades of shale-hosted igneous related zinc-lead (SHig) deposits

42. Cumulative frequency of average copper grades of shale-hosted igneous-related zinc-lead (SHig) deposits.

43. Cumulative frequency of average silver grades of shale-hosted igneous-related zinc-lead (SHig) deposits

44. Cumulative frequency of average gold grades of shale-hosted igneous-related zinc-lead (SHig) deposits

45. Cumulative frequency of ore tonnage of sandstone-hosted lead deposits ..............58

46. Cumulative frequency of zinc grades of sandstone-hosted lead deposits...............59

47. Cumulative frequency of lead grades of sandstone-hosted lead deposits...............60

48. Cumulative frequency of copper grades of sandstone-hosted lead deposits..........61

49. Cumulative frequency of silver grades of sandstone-hosted lead deposits... 


\section{Introduction}

This report provides information on sediment-hosted zinc-lead mineral deposits based on the geologic settings that are observed on regional geologic maps. The foundation of mineral-deposit models is information about known deposits. The purpose of this publication is to make this kind of information available in digital form for sediment-hosted zinc-lead deposits.

Mineral-deposit models are important in exploration planning and quantitative resource assessments: Grades and tonnages among deposit types are significantly different, and many types occur in different geologic settings that can be identified from geologic maps. Mineral-deposit models are the keystone in combining the diverse geoscience information on geology, mineral occurrences, geophysics, and geochemistry used in resource assessments and mineral exploration. Too few thoroughly explored mineral deposits are available in most local areas for reliable identification of the important geoscience variables, or for robust estimation of undiscovered deposits - thus, we need mineral-deposit models. Globally based deposit models allow recognition of important features because the global models demonstrate how common different features are. Well-designed and -constructed deposit models allow geologists to know from observed geologic environments the possible mineral-deposit types that might exist, and allow economists to determine the possible economic viability of these resources in the region. Thus, mineral-deposit models play the central role in transforming geoscience information to a form useful to policy makers.

This publication contains a computer file of information on sediment-hosted zinclead deposits from around the world. It also presents new grade and tonnage models for nine types of these deposits and a file allowing locations of all deposits to be plotted in Google Earth. The data are presented in FileMaker Pro, Excel and text files to make the information available to as many as possible. The value of this information and any derived analyses depends critically on the consistent manner of data gathering. For this reason, we first discuss the rules applied in this compilation. Next, the fields of the data file are considered. Finally, we provide new grade and tonnage models that are, for the most part, based on a classification of deposits using observable geologic units from regional-scaled maps.

\section{Deposits Selected}

A mineral deposit is a mineral occurrence of sufficient size and grade that might, under the most favorable circumstances, be considered to have economic potential (Cox, Barton, and Singer, 1986). Deposits sharing a relatively wide variety and large number of attributes are characterized as a "type," and a model representing that type can be developed. Sediment-hosted $\mathrm{Zn}-\mathrm{Pb}$ deposits are hosted in a variety of sedimentary rocks and have commonly been classified into skarns, polymetallic replacements, Mississippi Valley Zn-Pb (MVT), Sedimentary-exhalative Zn-Pb (SEDEX), sandstone-hosted Pb, Kipushi, and polymetallic vein types. Some of these types have been further subdivided by various authors (Allen, 2003). In this study we include all of these types except polymetallic vein deposits because of their relatively small size. 


\section{Spatial Rules Used}

An important consideration at the data gathering stage is the question of what the sampling unit should be. Grade and tonnage data are available to varying degrees for districts, deposits, mines, and shafts. For the deposits in this file, the following rule was used to determine which ore bodies were combined.

All mineralized rock or alteration within two kilometers was combined into one deposit for these deposits. Thus, if the alteration zones of two deposits are within two kilometers of each other, they were combined. Such an operational spatial rule is necessary for defining deposits because we must be able to classify deposits in regions with highly variable geologic information and to avoid bias in estimating undiscovered deposits in resource assessments in areas where detailed information is lacking, such as under cover. The two-kilometer rule was developed to try to insure that deposits in grade and tonnage and spatial density models correspond to deposits as geologic entities. Rules, such as the two-kilometer rule applied here, are essential in order to have an internally consistent assessment system where the estimated number of undiscovered deposits is consistent with the grade and tonnage model.

\section{Data Fields}

The information on the sediment-hosted $\mathrm{Zn}-\mathrm{Pb}$ deposits is contained in the files SedZnPb.fp7, SedZn-Pb.txt, and SedZn-Pb.xls, which are FileMaker Pro 9, tab-delineated text, and Excel, files respectively. The fields in the files are described below.

\section{Deposit Name}

The most recent deposit name, "NameDeposit," is used. Another field, "OtherNames," contains alternative names that have been used for the deposit. A third field, "Includes," provides the names of deposits that have been combined with the primary deposit as a result of the two-kilometer minimum separation rule.

\section{Locations}

A number of fields are provided to show the deposit's location. "Country" and "State/Province" are used for general locations. "CountryCode" is an abbreviated version of the country information. Degrees, minutes, and, in some cases, seconds of longitude and latitude are provided in the separate fields. Decimal degrees of latitude ("LatitudeDecimal") and longitude ("LongitudeDecimal") are calculated from the degrees, minutes and seconds fields. Southern latitudes and western longitudes are negative values. All deposit locations have been checked with Google Earth. As a result, many deposits have locations in these files that are substantially different than published locations.

\section{Grades And Tonnages}

Data gathered for each deposit include average grade of each metal or mineral commodity of possible economic interest and the associated tonnage based on the total production, reserves, and resources at the lowest possible cutoff grade. All further references to tonnage follow this definition. All tonnages reported here ("Tonnage") are in millions of metric tons. Zinc, lead, and copper grades are reported as a percentage of the metals. Gold and silver grades are reported as grams/metric ton of the metal. Grades 
not available (always for by-products) are treated as zero. Deposits that are known to be only partially drilled are considered as prospects, and their grades and tonnages are not reported in the grade and tonnage fields in order to avoid introduction of biases. The "Comments" field contains supplementary information about incompletely explored deposits and some grades, such as Co, when available. Two significant digits are presented for zinc, lead, copper, gold, and silver grades, but three significant digits are used for tonnage.

\section{Age}

In the field "DepositAge," ages are in standard divisions of geologic time or in millions of years, when available (Remane, 1998). Ages are reported in millions of years before the present ("AgeMY" field) based on reported absolute (typically thermal dates) ages or midpoints of geologic time scale units (Remane, 1998).

\section{Mineralogy}

Information on the mineralogy of the deposits varies widely in quantity and quality. Depending on the purpose of a study and the researcher's interest, a report on a mineral deposit might contain a detailed list of alteration minerals and a mention of unnamed sulfide and sulfosalt minerals, a detailed list of ore minerals and mention of alteration in broad terms, a complete list of all minerals, or a sparse list of minerals. In some studies, the authors attempted to list the relative or absolute amounts of each mineral. Unfortunately, these attempts are not common and are frequently not comparable with many other reports because of different standards. Thus, it was decided to use only the presence or absence of minerals ("Minerals") in this file. Most rockforming minerals, such as feldspar, calcite, and quartz, are not included. Some variants of rock forming minerals that may be related to mineralization or alteration, such as $\mathrm{Ag}$ calcite, are included.

\section{Types of Sediment-Hosted Zinc-Lead Deposits}

Sediment-hosted $\mathrm{Zn}-\mathrm{Pb}$ deposits are hosted in a variety of sedimentary rocks, and those listed in the "PreviousType" field have been classified according to the most common reporting of the deposits into skarns (ZnSkarn), polymetallic replacements (POLYREPL), Mississippi Valley Zn-Pb (MVT), Sedimentary-exhalative Zn-Pb (SEDEX), sandstone-hosted $\mathrm{Pb}$ (SSPb), and Kipushi (Kipushi) types. There is extensive literature on these deposit types (Goodfellow, Lydon, and Turner, 1993; Hitzman, 2003; Large, 1981,1983; Leach and Sangster, 1993; Leach and others, 2005; Sangster and Hillary, 1998; Sverjensky, 1986). For some deposits in this file there are differences in opinion about the correct classification. We have tried to select the prevalent or the most recently published class. Our attempts to use common classifications of many of these deposits in assessments failed because many of the classifications were found to be based on information only obtainable within discovered deposits and subject to detailed studies. The kinds of mineral resource assessments our deposit models are designed for are typically based on geologic maps at 1:1,000,000 to 1:100,000 scale. We found it difficult to delineate some of the geologic settings where commonly used classifications of sediment-hosted zinc-lead deposits could exist using geologic maps at these scales. In addition, when classing known deposits, most of the deposits classed as Sedimentaryexhalative $\mathrm{Zn}-\mathrm{Pb}$ that contained gold also apparently had a later igneous event with 
associated skarn-like alteration. These deposits have many attributes that are similar to polymetallic replacement deposits, and it is far from simple to definitely determine which deposit class is appropriate for many of these deposits.

In an attempt to solve this problem, we have tried to classify most of these deposits in the field "Type Deposit" according to the observed rocks reported in maps rather than frequently unobservable characteristics within yet-to-be discovered deposits. Unfortunately thicknesses of each rock type near a mineral deposit are rarely reported, so we cannot state the exact proportions of different kinds of rocks associated with these deposits. From publications about the deposits we commonly can identify the predominate rock types. Host rocks were classed as predominately carbonate (CA), shale (SH), or mixed lithology (ML):

- Carbonate (CA) This category includes rocks of massive carbonate sequences and carbonate-shale intercalations. Fifty percent of these deposits are hosted by dolomite and dolomitic rocks and 50percent by limestone. The "dolomite index" increases to 72 percent in SEDEX and to 62 percent in MVT deposits. Carbonaceous rocks, mainly interlayered shale, only occur in 8 percent of these predominantly carbonate-hosted deposits (17 percent in SEDEX).

- Shale (SH). This lithological category includes argillite, mudstone, phyllite, siltstone, and slate, according to terminologies from original descriptions of deposits. Forty-seven percent of deposits of the group are hosted by dolomitic shale and/or shale associated with dolomite in the ore-hosting strata. Carbonaceous (or graphitic) shale is characteristic for 62 percent of the deposits. A presence of tuff and tuffaceous rocks is noted in 42 percent of the deposits.

- Mixed Lithology (ML). This category could be considered "questionable" or "problematic" because the group includes highly metamorphosed deposits, such as Broken Hill, where researchers interpreted either sedimentary or volcanic original rock compositions. It is possible that host rocks of such deposits had contained mafic (amphibolite) and felsic (mica schist) volcanics, as well as carbonate rocks (calc-silicate rocks) and clastic rocks (mica schist). The group mostly coincides with the Broken Hill-type (BHT) in popular classifications (Penney and others, 2004a,b; Leach and others, 2005). BHT really is characterized by complex mixed lithology, including such exotic rocks as garnet quartzite, gahnite quartzite, tourmalinite, and sulfide-bearing iron-formation.

In addition, if the host rocks were affected by igneous events, the host-rock designation was modified as "ig;" if known to be amagmatic they were modified as "am;" and if it was not clear if there had been an igneous event, such as in highly metamorphosed rocks, they were modified as "me."

- Amagmatic (am) includes deposits without igneous manifestations and signs of contact metamorphism in the deposit area and vicinity. Regional metamorphism of country rocks range from "unmetamorphosed" to pregreenschist and greenschist facies. This group contains 90 percent of MVT 
deposits and 59 percent of SEDEX deposits. The deposits commonly have simple ore mineralogy.

- Igneous related (ig) consists of deposits with various igneous intrusions, also sills and numerous dikes, and signs of contact metamorphism of country rocks in the deposit area or in its vicinity, independent of the grade of regional metamorphism. Igneous events that are clearly older than host rock were ignored. Also not counted were ultramafic rocks, basalt sills, and diabase dikes. All polymetallic replacement and skarn deposits are in this category. SEDEX and a few MVT deposits affected by intrusions and contact metamorphism can have similar complicated mineralogical ore compositions that may be difficult to distinguish from skarns and replacements.

- Metamorphic (me) includes deposits exhibiting high-grade metamorphism of amphibolite to amphibolite-to-granulite facies including 20 deposits commonly classed as SEDEX and generally hosted by Proterozoic rocks with single Cambrian rock ages. Aside from carbonate marble beds, the original host-rock lithology cannot be recognized reliably. Mineralogical ore compositions are close to deposits of the previous category (ig) but are not as diverse. Data on this category are scarce.

Thus, a carbonate-hosted deposit with a nearby igneous event would be classed as "CAig" and a shale-hosted deposit with no igneous event would be classed as "SHam." This scheme lead to the classes "CAam," "CAig," "CAme," "SHig," "SHam," "MLig," and "MLme." The classes "SHme" and "MLam" contained no deposits. The common deposit types "Kipushi" and sandstone-hosted $\mathrm{Pb}(\mathrm{SSPb})$ did not fit this scheme and were retained along with the new classes in the field "Type Deposit." The Kipushi class contains only nine deposits, and from this sample we could not identify regional-scale attributes that would help delineate permissive geologic settings. For Kipushi deposits, we suggest the descriptive model of Cox and Bernstein (1986). It is important that the above operational classification of sediment-hosted $\mathrm{Zn}-\mathrm{Pb}$ deposits into types is based on observable geologic units reported in the scale of maps frequently used in assessments and, as such, is used in the associated grade and tonnage models reported below.

\section{Size and Shape of Alteration and Ore Bodies}

Because the alteration zones around mineral deposits might be significantly larger than the sizes of the ore bodies, they are of interest in exploration. For some deposit types, sizes of alteration zones are related to the amounts of metal in the deposits (Singer, Berger, and Moring, 2008). To capture information about the size and shape of alteration and ore bodies consistently, as represented in two-dimensional projection to the surface, we use the rigorous procedures used for mineral-grain images (Griffiths, 1967). The shortest dimension ( $b$ axis) is measured as the distance between parallel rules that just touch the object. After the short dimension is determined, the long axis is measured perpendicular to the $b$ axis using the same criteria. Many of the alteration and ore zones can be well represented by an ellipse. Where published estimates of the projected area of the body are not available, we estimated the area using the standard formula for area of an ellipse ( area $=3.14159 \mathrm{a} \mathrm{b} / 4)$. In some cases, however, the body has significant concave parts, and use of an ellipse to estimate area of the body would result in an over estimate of the area. The field "AlterArea" represents the area of alteration in square 
kilometers; the alteration minor axis in kilometers is in the field "AlterWidth," and the major axis is in the field "AlterLength." The area of ore in square kilometers is in the field "AreaOre," the major axis of ore is in "DepositLength," and the minor axis in "DepositWidth." Where known, the deposit thickness is recorded as "DepositThick."

\section{Host and Associated Rocks}

Rocks that host the sediment-hosted $\mathrm{Zn}-\mathrm{Pb}$ deposits are recorded as "Host Rock" in the same terms used in the published maps and reports. Reports of rocks from different sources were treated equally rather than attempting to resolve differing names for what might or might not be the same rock type. Also listed in this field are ages reported, breccias reported, and karsts if known. Reported rocks are listed alphabetically without regard to their relative thicknesses. Typically, the most common rock types, such as various kinds of carbonate rocks, are listed more frequently in the host-rock field when the mineral deposits are classed as a carbonate type. We have used six other fields in an attempt to provide additional information about the geologic settings of each deposit. The field "Rocks Overlying" is used for rocks that are reported above the rocks hosting the deposit. The "Rocks Underlying" field is for the rocks lying under the host rocks. There are fields for the thicknesses of each of these units; "Host RockThick(m)," "Overlying RockThick(m)," and "Underlying RockThick(m)."

\section{Discontinuities}

The discontinuities reported here can be either disconformities between parallel host-rock strata or angular unconformities in the host rocks. The number of discontinuities ("NumberDiscontinuities") and/or the kinds of discontinuities ("Discontinuity") are reported for the host rocks. In some cases, the number or kind of discontinuity was not reported in the literature, but the presence or absence was reported. For these cases, we use a simple "yes" or "no."

\section{Igneous Rocks}

Igneous rocks (and their ages) are recorded ("IgneousRelatedRock") if the event may be as young or younger than the mineral deposit. Thin layers of ash are recorded in the host-rock field rather than here.

\section{Tectonic Setting}

The age and general tectonic setting of the deposit is reported in the field "Tectonostrat setting."

\section{Deformation and Metamorphism}

Metamorphism of the host rocks is recorded in the "Host Rock Metamorph" field, and deformation of the host rocks is presented in the "Host Rock Deform" field.

\section{Spatially Related Deposits}

Here we record other deposits by type that are within $5 \mathrm{~km}$ ("OtherDeposits $<$ $5 \mathrm{~km}$ ") and between 5 and $10 \mathrm{~km}$ ("OtherDeposits $>5 \mathrm{~km}<10 \mathrm{~km}$ ") of a sediment-hosted $\mathrm{Zn}-\mathrm{Pb}$ deposit. In many situations, these other deposits are merely occurrences and are not economic mineral deposits. Nevertheless, many of these occurrences can be typed and their types might provide important information about possible sediment-hosted Zn- 
$\mathrm{Pb}$ deposits. Each deposit type is coded as the deposit-type number and deposit type as listed in USGS Bulletins 1693 (Cox and Singer, 1986) and 2004 (Bliss, 1992). Codes for the deposit types used here are listed in table 1. In most cases the age of spatially associated deposits is not known. No attempt is made here to record the age in the rare case where it is known.

Table 1-Names of deposit types and their associated codes used in the "OtherDeposits" fields.

\begin{tabular}{|l|l|l|l|}
\hline Deposit type & $\begin{array}{l}\text { Type } \\
\text { code }\end{array}$ & Deposit type & $\begin{array}{l}\text { Type } \\
\text { code }\end{array}$ \\
\hline komatiitic $\mathrm{Ni}-\mathrm{Cu}$ & $6 \mathrm{a}$ & Creede epithermal veins & $25 \mathrm{~b}$ \\
\hline dunitic Ni-Cu & $6 \mathrm{~b}$ & Comstock epithermal veins & $25 \mathrm{c}$ \\
\hline synorogenic-synvolcanic Ni-Cu & $7 \mathrm{a}$ & epithermal quartz-alunite $\mathrm{Au}$ & $25 \mathrm{e}$ \\
\hline anorthosite Ti & $7 \mathrm{~b}$ & volcanogenic U & $25 \mathrm{f}$ \\
\hline minor podiform chromite & $8 \mathrm{a}$ & epithermal Mn & $25 \mathrm{~g}$ \\
\hline carbonatite & 10 & vocanic-hosted magnetite & $25 \mathrm{i}$ \\
\hline Climax Mo $\mathrm{Mo}$ & 16 & sediment hosted Au & $26 \mathrm{a}$ \\
\hline porphyry $\mathrm{Cu}$ & 17 & hot-spring $\mathrm{Hg}$ & $27 \mathrm{a}$ \\
\hline basaltic $\mathrm{Cu}$ & 23 & silica-carbonate $\mathrm{Hg}$ & $27 \mathrm{c}$ \\
\hline W skarn & $14 \mathrm{a}$ & simple Sb & $27 \mathrm{~d}$ \\
\hline Sn skarn & $14 \mathrm{~b}$ & kuroko massive sulfide & $28 \mathrm{a}$ \\
\hline replacement Sn & $14 \mathrm{c}$ & Algoma Fe & $28 \mathrm{~b}$ \\
\hline W veins & $15 \mathrm{a}$ & sandstone-hosted Pb-Zn & $30 \mathrm{a}$ \\
\hline Sn veins & $15 \mathrm{~b}$ & sandstone-hosted Cu & $30 \mathrm{~b}$ \\
\hline porphyry $\mathrm{Cu}$, skarn-related deposits & $18 \mathrm{a}$ & sandstone U & $30 \mathrm{c}$ \\
\hline Cu skarn deposits & $18 \mathrm{~b}$ & sedimentary exhalative Zn-Pb & $31 \mathrm{a}$ \\
\hline Zn-Pb skarn deposits & $18 \mathrm{c}$ & bedded barite / exhalative barite & $31 \mathrm{~b}$ \\
\hline Fe skarn & $18 \mathrm{~d}$ & southeast Missouri Pb-Zn & $32 \mathrm{a}$ \\
\hline polymetallic replacement & $19 \mathrm{a}$ & Appalachian $\mathrm{Zn}$ & $32 \mathrm{~b}$ \\
\hline porphyry $\mathrm{Sn}$ & $20 \mathrm{a}$ & Kipushi Cu-Pb-Zn & $32 \mathrm{c}$ \\
\hline porphyry Cu-Au & $20 \mathrm{c}$ & sedimentary Mn & $34 \mathrm{~b}$ \\
\hline porphyry Cu-Mo & $21 \mathrm{a}$ & low-sulfide Au-quartz veins & $36 \mathrm{a}$ \\
\hline porphyry Mo, low-F & $21 \mathrm{~b}$ & Homestake Au & $36 \mathrm{~b}$ \\
\hline polymetallic veins & $22 \mathrm{c}$ & uncomformity U-Au & $37 \mathrm{a}$ \\
\hline Cyprus massive sulfide & $24 \mathrm{a}$ & lateritic Ni & $38 \mathrm{a}$ \\
\hline Besshi massive sulfide & $24 \mathrm{~b}$ & lateritic type bauxite deposits & $38 \mathrm{~b}$ \\
\hline volcanogenic Mn & $24 \mathrm{c}$ & karst type bauxite deposits & $38 \mathrm{c}$ \\
\hline hot-spring Au-Ag & $25 \mathrm{a}$ & placer Au-PGE & $39 \mathrm{a}$ \\
\hline Activity & & & \\
\hline
\end{tabular}

\section{Activity}

Where the discovery date is known it is recorded in the field "DiscoveryDate." If mining is known to have started, the date is listed in the "StartupDate" field.

\section{Sources}

Sources include the papers and Web sites that were used for each deposit ("References"). In a few cases unpublished sources were used. 


\section{Grade and Tonnage Models}

Grade and tonnage models of mineral deposits are useful in quantitative resource assessments and exploration planning. Having some idea of the possible values of alternative kinds of deposits that might be sought is critical to good exploration planning. In quantitative resource assessments these models play two roles. First, grade and tonnage models can help classify the known well-explored deposits in a region into types and, therefore can aid in delineation of areas permissive for types. Second, the models provide information about the potential value of undiscovered deposits in the assessment area and are key to economic analyses of these resources. Construction of grade and tonnage models involves multiple steps; the first step is the identification of a group of well-explored deposits that are believed to belong to the mineral-deposit type being modeled. Well-explored in this report means completely drilled in three dimensions. After deposits are identified, data from each are compiled. These data consist of average grades of each metal or mineral commodity of possible economic interest and tonnages based on the total production, reserves, and resources at the lowest available cutoff grade. Here we use the deposits that have tonnages recorded in the "Tonnage" field and exclude deposits with grades and tonnages only in the "Comments" field because we believe more exploration is needed for these deposits.

Relationships among variables are important for simulations of resources, for their affect on our understanding of how deposits form and for their affect on our assumptions about resource availability. Deposits used in these models are typed as reported in the field "Type Deposit." Tonnage is correlated with zinc grade $(\mathrm{r}=-0.30 * *$, $\mathrm{n}=128$ ) in the CAam (carbonate-hosted amagmatic) group, but the correlation is not significant if two deposits with suspiciously low zinc grades are not considered $(* *$ means significant at the 1 percent level). Tonnage is also correlated with lead grade $(\mathrm{r}=-0.29 * *$, $\mathrm{n}=166$ ) in the CAig (carbonate-hosted igneous) group. Zinc grade is correlated with lead grade in the CAam group $\left(\mathrm{r}=0.16^{* *}, \mathrm{n}=117\right)$, in the CAig group $\left(\mathrm{r}=0.25^{* *}, \mathrm{n}=164\right)$, and in the SHam group $\left(\mathrm{r}=0.72^{* *}, \mathrm{n}=25\right)$. Lead grade is correlated with silver grade in the CAam group $\left(\mathrm{r}=0.45^{* *}, \mathrm{n}=56\right)$, in the CAig group $\left(\mathrm{r}=0.51^{* *}, \mathrm{n}=131\right)$, in the MLig group $\left(\mathrm{r}=0.55^{* *}, \mathrm{n}=26\right)$, and in the MLme group $\left(\mathrm{r}=0.93^{* *}, \mathrm{n}=6\right)$. Copper is correlated with silver grade in the Kipushi group $(r=0.92 * *, n=6)$.

Frequency distributions of the tonnages, zinc, lead, copper, silver, and gold grades of the well-explored sediment-hosted deposits reported in the file can be employed as models of the grades and tonnages of undiscovered deposits. Here these frequencies are plotted in figures 1-49 and are summarized in table 2 for the nine types of sedimenthosted zinc-lead deposits. Plots were not made if only one or two deposits had a reported grade. Grade and tonnage models are presented in a graphical format to make it easy to compare deposit types and to display the data. The grade and tonnage plots show the cumulative proportion of deposits versus the tonnage or grade of the deposits. Individual symbols representing the deposits and intercepts for the 90th, 50th, and 10th percentiles are plotted. Percentiles of grades that contain unreported values, such as $\mathrm{Cu}, \mathrm{Ag}$, and $\mathrm{Au}$, were based on the observed distributions. Based on the Shapiro-Wilk W test, $\mathrm{Zn}$ in the CAam, CAig, and SHam groups, $\mathrm{Pb}$ in the CAig group, Au in the CAam group, and Ag in the CAme groups, are each significantly different than the lognormal distribution at the one percent level. The deposits contributing to the differences can be seen in the respective grade plots. In most cases the departures from normality appear to be due to a 
small number of deposits that have very low reported grades. Because these are at the low-grade tail of the distributions and represent a small number of deposits, they might not be important for modeling purposes. Lead in the SHig group is also significantly different than lognormal due to about a quarter of deposits with lower grades than the main group.

Table 2 - Grade and tonnage models of sediment-hosted $\mathrm{Zn}-\mathrm{Pb}$ deposits by type. [Tonnage reported in millions of metric tons, zinc, lead, and copper grades in percent. Gold and silver grades reported in grams per metric ton.]

\begin{tabular}{|c|c|c|c|c|c|}
\hline Type & & $\begin{array}{l}\text { Number } \\
\text { deposits }\end{array}$ & $\begin{array}{l}\text { 10th } \\
\text { percentile } \\
\text { of deposits }\end{array}$ & $\begin{array}{l}\text { 50th percentile } \\
\text { of deposits }\end{array}$ & $\begin{array}{l}\text { 90th percentile } \\
\text { of deposits }\end{array}$ \\
\hline \multirow[t]{6}{*}{ CAam } & Tons & 132 & 86.0 & 10.0 & 0.93 \\
\hline & Zn grade & 132 & 12.0 & 5.1 & 1.7 \\
\hline & $\mathrm{Pb}$ grade & 132 & 5.0 & 1.5 & 0.19 \\
\hline & $\mathrm{Cu}$ grade & 132 & 0.0 & 0.0 & 0.0 \\
\hline & Ag grade & 132 & 37.0 & 0.0 & 0.0 \\
\hline & Au grade & 132 & 0.0 & 0.0 & 0.0 \\
\hline \multirow[t]{6}{*}{ CAig } & Tons & 187 & 61.0 & 6.4 & 0.33 \\
\hline & Zn grade & 187 & 11.0 & 5.0 & 1.4 \\
\hline & $\mathrm{Pb}$ grade & 187 & 8.7 & 2.6 & 0.0 \\
\hline & $\mathrm{Cu}$ grade & 187 & 0.92 & 0.0 & 0.0 \\
\hline & Ag grade & 187 & 390.0 & 49.0 & 0.0 \\
\hline & Au grade & 187 & 2.0 & 0.0 & 0.0 \\
\hline \multirow{4}{*}{ CAme } & Tons & 7 & 81.0 & 5.0 & 0.54 \\
\hline & Zn grade & 7 & 16.0 & 5.0 & 2.3 \\
\hline & $\mathrm{Pb}$ grade & 7 & 4.0 & 2.1 & 0.0 \\
\hline & Ag grade & 7 & 34.0 & 29.0 & 0.0 \\
\hline \multirow[t]{5}{*}{ Kipushi } & Tons & 8 & 100.0 & 21.0 & 0.50 \\
\hline & Zn grade & 8 & 12.0 & 0.0 & 0.0 \\
\hline & $\mathrm{Pb}$ grade & 8 & 10.0 & 1.4 & 0.0 \\
\hline & $\mathrm{Cu}$ grade & 8 & 10.0 & 2.2 & 1.2 \\
\hline & Ag grade & 8 & 580.0 & 32.0 & 0.0 \\
\hline \multirow[t]{6}{*}{ MLig } & Tons & 38 & 130.0 & 8.6 & 1.4 \\
\hline & Zn grade & 38 & 11.0 & 3.7 & 0.98 \\
\hline & $\mathrm{Pb}$ grade & 38 & 8.5 & 2.0 & 0.0 \\
\hline & $\mathrm{Cu}$ grade & 38 & 0.79 & 0.0 & 0.0 \\
\hline & Ag grade & 38 & 130.0 & 27.0 & 0.0 \\
\hline & Au grade & 38 & 0.48 & 0.0 & 0.0 \\
\hline \multirow[t]{6}{*}{ MLme } & Tons & 12 & 140.0 & 2.2 & 0.56 \\
\hline & Zn grade & 12 & 10.0 & 3.3 & 0.62 \\
\hline & $\mathrm{Pb}$ grade & 12 & 5.1 & 1.5 & 0.17 \\
\hline & $\mathrm{Cu}$ grade & 12 & 1.1 & 0.0 & 0.0 \\
\hline & Ag grade & 12 & 61.0 & 3.0 & 0.0 \\
\hline & Au grade & 12 & 0.21 & 0.0 & 0.0 \\
\hline
\end{tabular}




\begin{tabular}{|l|l|c|c|c|c|}
\hline SHam & Tons & 25 & 300.0 & 25.0 & 5.0 \\
\hline & Zn grade & 25 & 14.0 & 8.0 & 2.3 \\
\hline & Pb grade & 25 & 5.3 & 2.1 & 0.88 \\
\hline & Cu grade & 25 & 1.0 & 0.0 & 0.0 \\
\hline & Ag grade & 25 & 71.0 & 21.0 & 0.0 \\
\hline & Au grade & 25 & 0.18 & 0.0 & 0.0 \\
\hline SHig & Tons & 32 & 140.0 & 12.0 & 0.55 \\
\hline & Zn grade & 32 & 15.0 & 6.6 & 1.2 \\
\hline & Pb grade & 32 & 6.7 & 3.7 & 0.9 \\
\hline & Cu grade & 32 & 0.75 & 0.0 & 0.0 \\
\hline & Ag grade & 32 & 130.0 & 54.0 & 0.0 \\
\hline & Au grade & 32 & 1.8 & 0.0 & 0.0 \\
\hline $\mathrm{SSPb}$ & Tons & 22 & 190.0 & 10 & 0.38 \\
\hline & Zn grade & 22 & 6.5 & 0.53 & 0.0 \\
\hline & Pb grade & 22 & 7.0 & 2.9 & 1.1 \\
\hline & Cu grade & 22 & 0.18 & 0.0 & 0.0 \\
\hline & Ag grade & 22 & 51.0 & 0.85 & 0.0 \\
\hline
\end{tabular}

If there were no differences in grades or tonnages among deposit types, we could use one model for all types. For this reason, we performed some tests to determine if the types are significantly different with respect to grade or tonnages. Analysis of variance tests of differences in mean tonnage and zinc, lead, copper, silver, and gold grades by type of sediment-hosted deposit reveal significant differences where all of the data are logged. Tonnages of the types are significantly different at the one percent level with the high tonnages of the SHam (shale-hosted amagmatic) group being the major contributor to the significance. Zinc grades are also significantly different, with the low zinc grades of the SSPb group and the high zinc grades of the SHam and SHig groups contributing to the differences. High grades in the Kipushi group and low grades in the CAam group drive the significantly different copper grades. Silver grades are also significantly different among the groups, with CAig, Kipushi, and SHig having high grades and CAam, CAme, and SSPb having low grades. In general, shale-hosted types have higher tonnages, zinc grades, and lead grades.

Although gold grades are not significantly different among the types at the one percent level $(p=0.045)$, it is useful to remember that these tests are made only for the deposits with reported grades. In the case of gold grades, many sediment-hosted zinc-lead deposits have such low gold grades that their grade never is reported. For example, the igneous-related types (CAig, MLig, SHig,) have gold grades reported for 91 of their 257 deposits, whereas the non igneous related types (CAam, CAme, MLme, Kipushi, SHam, $\mathrm{SSPb}$ ) have gold grades reported in only eight of the 206 deposits. When deposits are placed into these groups, gold grades are significantly higher for the igneous types compared to the non igneous types. Other effects of igneous events are clearly demonstrated by significantly higher lead and silver grades in the igneous related groups. Another measure of the importance of igneous events in the reporting of gold grades or minerals is presented in table 3 . 
Table 3-Reports of gold grades or minerals in sediment-hosted $\mathrm{Zn}-\mathrm{Pb}$ deposits by type. [Double counts removed.]

\begin{tabular}{|c|c|c|c|c|c|c|c|}
\hline Type & $\begin{array}{l}\text { Number } \\
\text { deposits }\end{array}$ & $\begin{array}{l}\text { Number } \\
\text { with } \\
\text { reported } \\
\mathrm{Au} \\
\text { grade }\end{array}$ & $\begin{array}{l}\text { Gold in } \\
\text { comments }\end{array}$ & $\begin{array}{l}\text { Gold as } \\
\text { mineral }\end{array}$ & Electrum & $\begin{array}{c}\text { Number } \\
\text { of } \\
\text { deposits } \\
\mathrm{Au}\end{array}$ & $\begin{array}{l}\text { Percent } \\
\text { of } \\
\text { deposits } \\
\mathrm{Au}\end{array}$ \\
\hline CAig & 200 & 70 & 16 & 12 & 3 & 101 & 51 \\
\hline CAme & 7 & 0 & 1 & 0 & 1 & 2 & 29 \\
\hline MLig & 39 & 7 & 1 & 2 & 0 & 10 & 26 \\
\hline SHig & 35 & 4 & 2 & 2 & 0 & 8 & 23 \\
\hline SHam & 31 & 4 & 1 & 0 & 0 & 5 & 16 \\
\hline MLme & 13 & 1 & 0 & 1 & 0 & 2 & 15 \\
\hline Kipushi & 9 & 0 & 0 & 1 & 0 & 1 & 11 \\
\hline $\mathrm{SSPb}$ & 24 & 0 & 1 & 0 & 0 & 1 & 4 \\
\hline CAam & 148 & 3 & 1 & 1 & 1 & 6 & 4 \\
\hline
\end{tabular}

\section{Location Map}

Rather than providing a map, we have included a file (Sed-Hosted_Zinc_USGS_OFR $2009-1252 . \mathrm{kmz}$ ) that plots the locations of the deposits in Google Earth, and we have provided a shapefile ( $\mathrm{SedZn-Pb}$ Shape) for use in mapmaking.

\section{References}

Allen, C., 2003, Tectonic setting of sediment-hosted (or Sedex) massive sulfide deposits: AIG (Australian Institute of Geoscientists) Newsletter, no. 72, p. 9-13.

Bliss, J.D., ed., 1992, Developments in deposit modeling: U.S. Geological Survey Bulletin 2004, 168 p. (http://pubs.usgs.gov/bul/b2004/ accessed December 9, 2009).

Cox, D.P., and Bernstein, L.R., 1986, Descriptive model of Kipushi Cu-Pb-Zn, in Cox, D.P., and Singer, D.A., eds., Mineral deposit models: U.S. Geological Survey Bulletin 1693, p. 227 (http://pubs.usgs.gov/bul/b1693/accessed December 9, 2009).

Cox, D.P., and Singer, D.A., eds., 1986, Mineral deposit models: U.S. Geological Survey Bulletin 1693, 379 p. (http://pubs.usgs.gov/bul/b1693/ accessed December 9, 2009).

Cox, D.P., Barton, P.R., and Singer, D.A., 1986, Introduction, in Cox, D.P., and Singer, D.A., eds., Mineral deposit models: U.S. Geological Survey Bulletin 1693, p. 110 (http://pubs.usgs.gov/bul/b1693/ accessed December 9, 2009).

Goodfellow, W.D., Lydon, J.W., and Turner, R.J.W., 1993 Geology and genesis of stratiform sediment-hosted (SEDEX) lead-zinc-silver sulphide deposits, in Kirkham, R.V., Sinclair, W.D., Thorpe, R.I., and Duke, J.M., eds, Mineral deposit modeling: Geological Association of Canada Special Paper 40, p. 201-251. 
Griffiths, J.C., 1967, Scientific method in analysis of sediments: New York, McGrawHill, 508 p.

Hitzman, M.W., 2003, The Irish Zn-Pb-(Ba-Ag) orefield, in Kelly, J.G., Andrew, C.J., Ashton, J.H., Boland, M.B., Earls, G., Fusciardi, L., and Stanley, G., eds., Europe's major base metal deposits: Dublin, Ireland, Irish Association for Economic Geology, p. 499-531.

Large, D.E., 1981, Geological parameters associated with sediment-hosted, submarine exhalative lead-zinc deposits-A review of their geological characteristics, in Wolf, K.H., ed., Handbook of strata-bound and stratiform ore deposits, v. 9 : Amsterdam, Elsevier, p. 469-507.

Large, D.E., 1983, Sediment-hosted massive sulfide lead-zinc deposits-An empirical model, in Sangster, D.F., ed., Sediment-hosted stratiform lead-zinc deposits: Short Course Handbook, Victoria, Mineralogical Association of Canada, v. 8, p. 1-29.

Leach, D.L., and Sangster, D.F., 1993, Mississippi Valley-type lead-zinc-silver deposits, in Kirkham, R.V., Sinclair, W.D., Thorpe, R.I., and Duke, J.M., eds, Mineral deposit modeling: Geological Association of Canada Special Paper 40, p. 289314.

Leach, D.L., Sangster, D.F., Kelley, K.D., Large, R.R., Garven, G., Allen C.R., Gutzmer, J., and Walters, S., 2005, Sediment-hosted lead-zinc deposits-A global perspective: Society of Economic Geologists, Economic Geology 100th Anniversary Volume, p. 561-607.

Penney, S.R., Allen, R.M., Harrison, S., Lees, T.C., Murphy, F.C., and Norman, A.R., 2004a, The global distribution of zinc mineralization, an analysis based on new zinc deposit database: Applied Earth Science, v. 113, p. B171-B182.

Penney, S.R., Allen, R.M., Harrison, S., Lees, T.C., Murphy, F.C., Norman, A.R., and Roberts, P.A., 2004b, A global-scale exploration risk analysis technique to determine the best mineral belts for exploration: Applied Earth Science, v. 113, p. B183-196.

Remane, Jürgen, 1998, Explanatory note to global stratigraphic chart, in Circular of International Subcommission on Stratigraphic Classification (ISSC) of IUGS Commission on Stratigraphy, Appendix B: International Union of Geological Sciences (IUGS) Commission on Stratigraphy, v. 93, 11 p.

Sangster, D.F., and Hillary, E.M., 1998, SEDEX deposits - proposed subtypes and their characteristics: Exploration and Mining Geology, v. 7, no. 4, p. 341-357.

Singer, D.A., Berger, V.I., and Moring, B.C., 2008, Porphyry copper deposits of the world: database, map, and grade and tonnage models, 2008: U.S. Geological Survey Open-file Report 2008-1155 (http://pubs.usgs.gov/of/2008/1155/ accessed December 9, 2009).

Sverjensky, D.A., 1986, Genesis of Mississippi Valley-type lead-zinc deposits: Annual Reviews of Earth Planet Sciences, v.14, p. 177-199.

\section{Disclaimers}

This publication was prepared by an agency of the United States Government. Neither the United States Government nor any agency thereof, nor any of their employees, makes any warranty, expressed or implied, or assumes any legal liability or responsibility for the accuracy, completeness, or usefulness of any information, 
apparatus, product, or process disclosed in this report, or represents that its use would not infringe privately owned rights. Reference therein to any specific commercial product, process, or service by trade name, trademark, manufacturer, or otherwise does not necessarily constitute or imply its endorsement, recommendation, or favoring by the United States Government or any agency thereof. This database, identified as SedZn$\mathrm{Pb} . f \mathrm{p} 7$, SedZn-PbTX.txt, and SedZn-PbEX2009.xls have been approved for release and publication by the Director of the USGS. Although this database has been subjected to rigorous review and is substantially complete, the USGS reserves the right to revise the data pursuant to further analysis and review. Furthermore, it is released on condition that neither the USGS nor the United States Government may be held liable for any damages resulting from its authorized or unauthorized use. The act of distribution shall not constitute any such warranty, and no responsibility is assumed by the USGS in the use of this data, software, or related materials.

\section{System Requirements}

The data and text require either a Macintosh or compatible computer or an IBM or compatible personal computer. The Macintosh should have a 68020 or higher processor (PowerPC recommended), 8 megabytes RAM (16 MB recommended), Apple System Software version 7.0 or later (7.1.2 or later recommended), and a 13- inch color monitor that can display thousands of colors. The PC should have a 386 or higher processor (Pentium recommended), Microsoft Windows 3.1 or higher (Windows 95, 98, or NT recommended), 8 megabytes RAM (16 MB recommended), and a VGA color monitor that can display 256 colors. Both platforms require Adobe Acrobat Reader 5.0 or higher or other software that can translate PDF files.

This was produced in accordance with the ISO 9660 and Macintosh HFS standards. All ASCII and TXT files can be accessed from DOS, Macintosh, and Unix platforms, the display software packages provided are designed for use under a DOSbased, Windows-based, or Macintosh system, as appropriate.

\section{Files}

of 2009-1252.pdf (A PDF file describing all contents; this file.)

COUNTRY_CODES.XLS (A text file relating country codes to country names.)

SedZn-Pb.fp7 (A FileMaker Pro 7 file containing the sediment-hosted $\mathrm{Zn}-\mathrm{Pb}$ database.) SedZn-PbTX.txt (A tab-delineated text file containing the sediment-hosted $\mathrm{Zn}-\mathrm{Pb}$ database.)

SedZn-PbEX2009.xls (An Excel file containing the sediment-hosted Zn-Pb database.)

Sed-Hosted_Zinc_USGS_OFR_2009-1252.kmz(A Google Earth file that can be used with Google Earth to show the locations of the sediment-hosted $\mathrm{Zn}-\mathrm{Pb}$ deposits.) $\mathrm{SedZn}-\mathrm{Pb}$ meta.txt (Metatdata in FGDC format.) SedZn_Shape.zip (A compressed file containing a shapefile to aid in mapmaking.) 


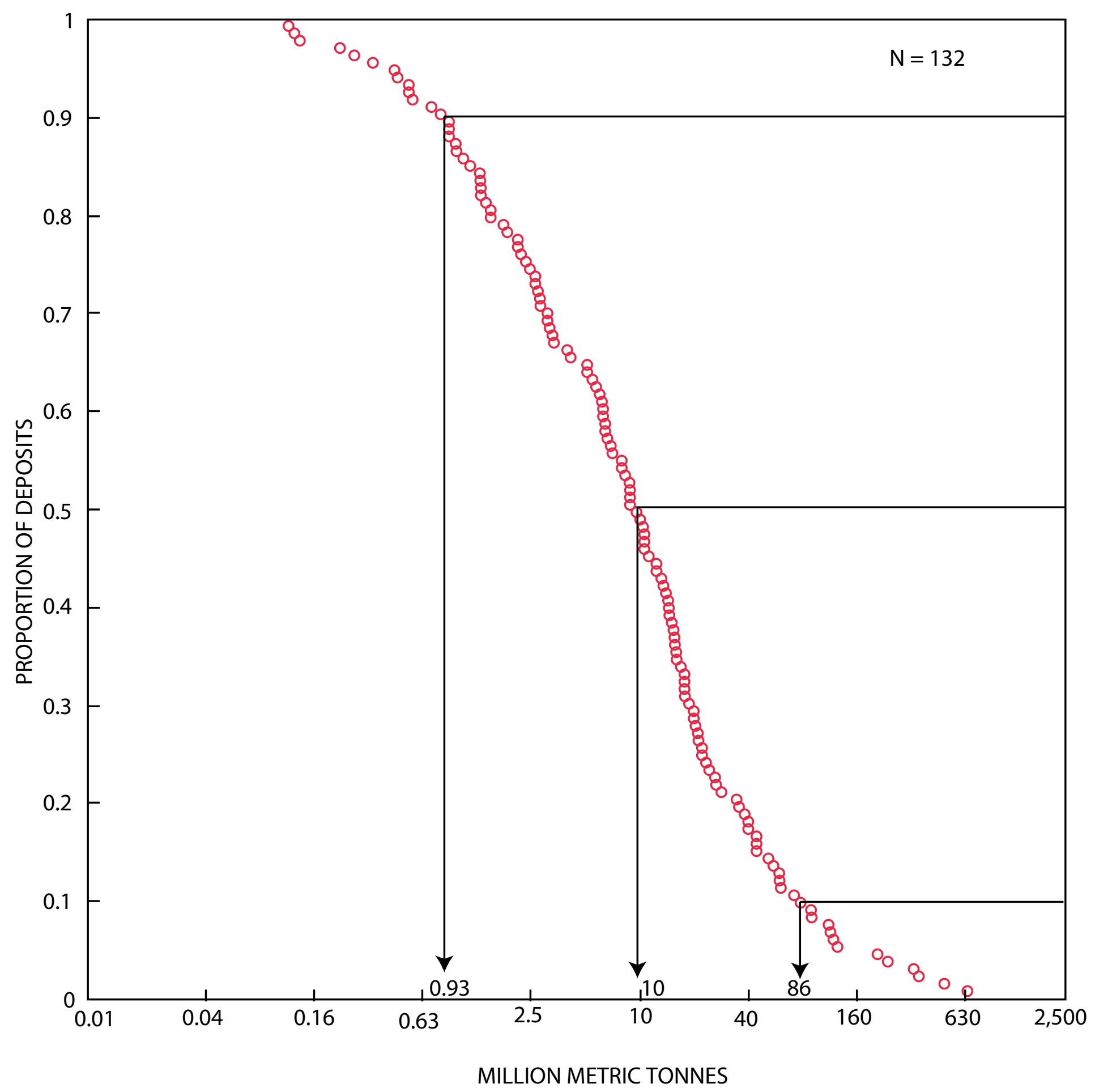

Figure 1. Cumulative frequency of ore tonnage of carbonate-hosted amagmatic zinc-lead (CAam) deposits. Each circle represents an individual deposit. Intercepts for the 90th, 50th, and 10th percentiles of the observed distribution are provided.

$\square$ 


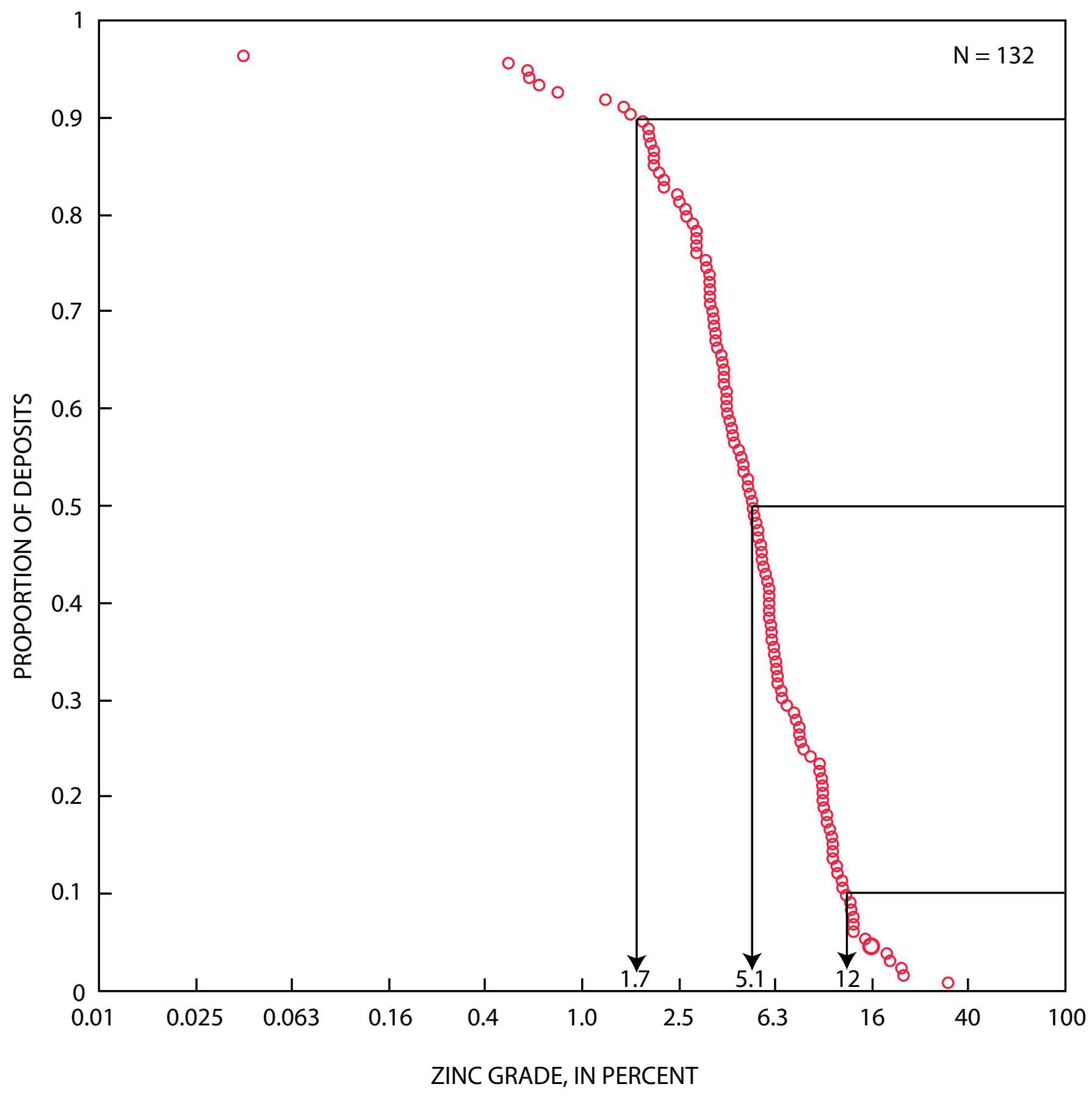

Figure 2. Cumulative frequency of average zinc grade of carbonate-hosted amagmatic zinc-lead (CAam) deposits. Each circle represents an individual deposit. Intercepts for the 90th, 50th, and 10th percentiles of the observed distribution are provided 


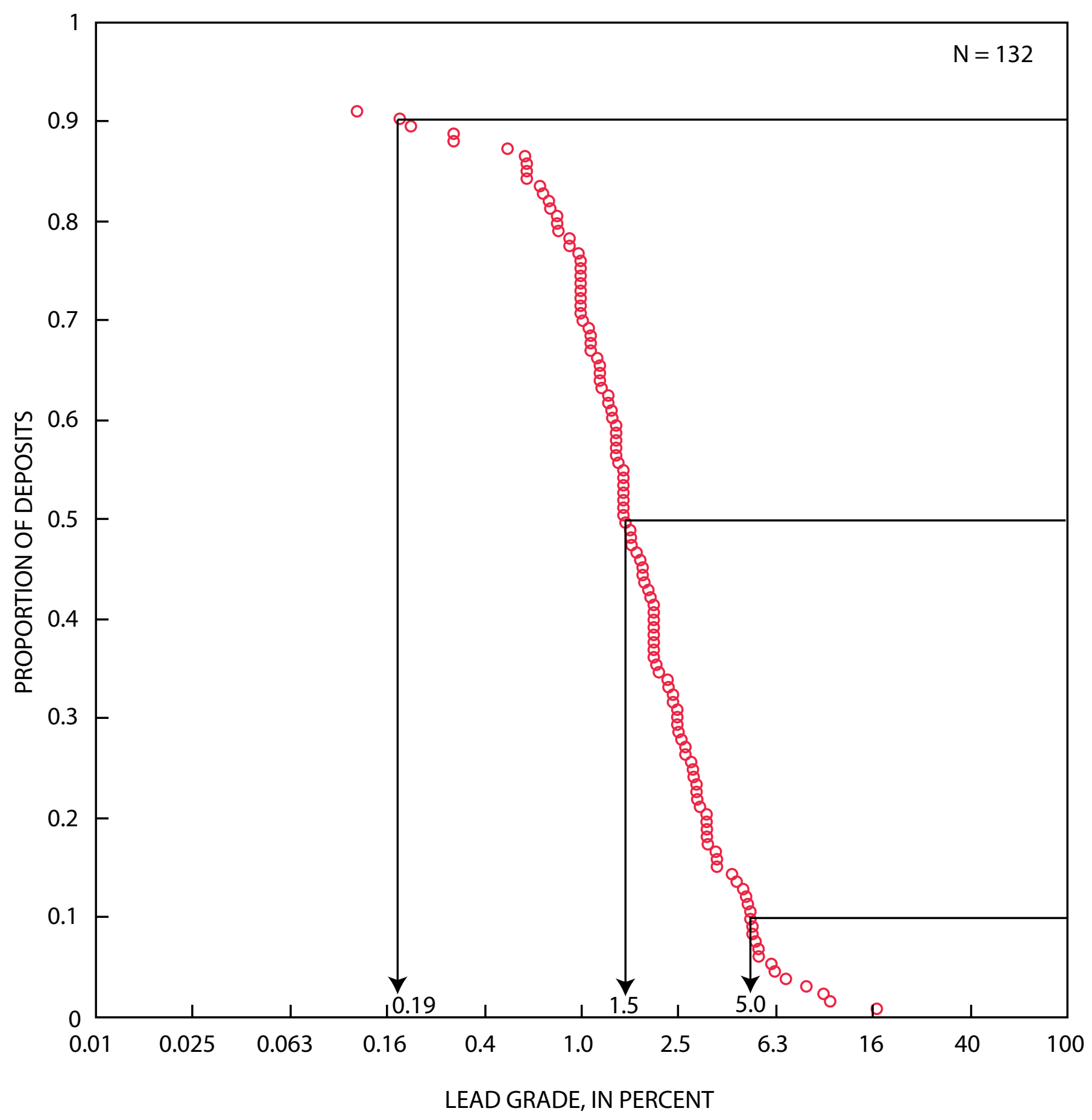

Figure 3. Cumulative frequency of average lead grade of carbonate-hosted amagmatic zinc-lead (CAam) deposits. Each circle represents an individual deposit. Intercepts for the 90th, 50th, and 10th percentiles of the observed distribution are provided. 


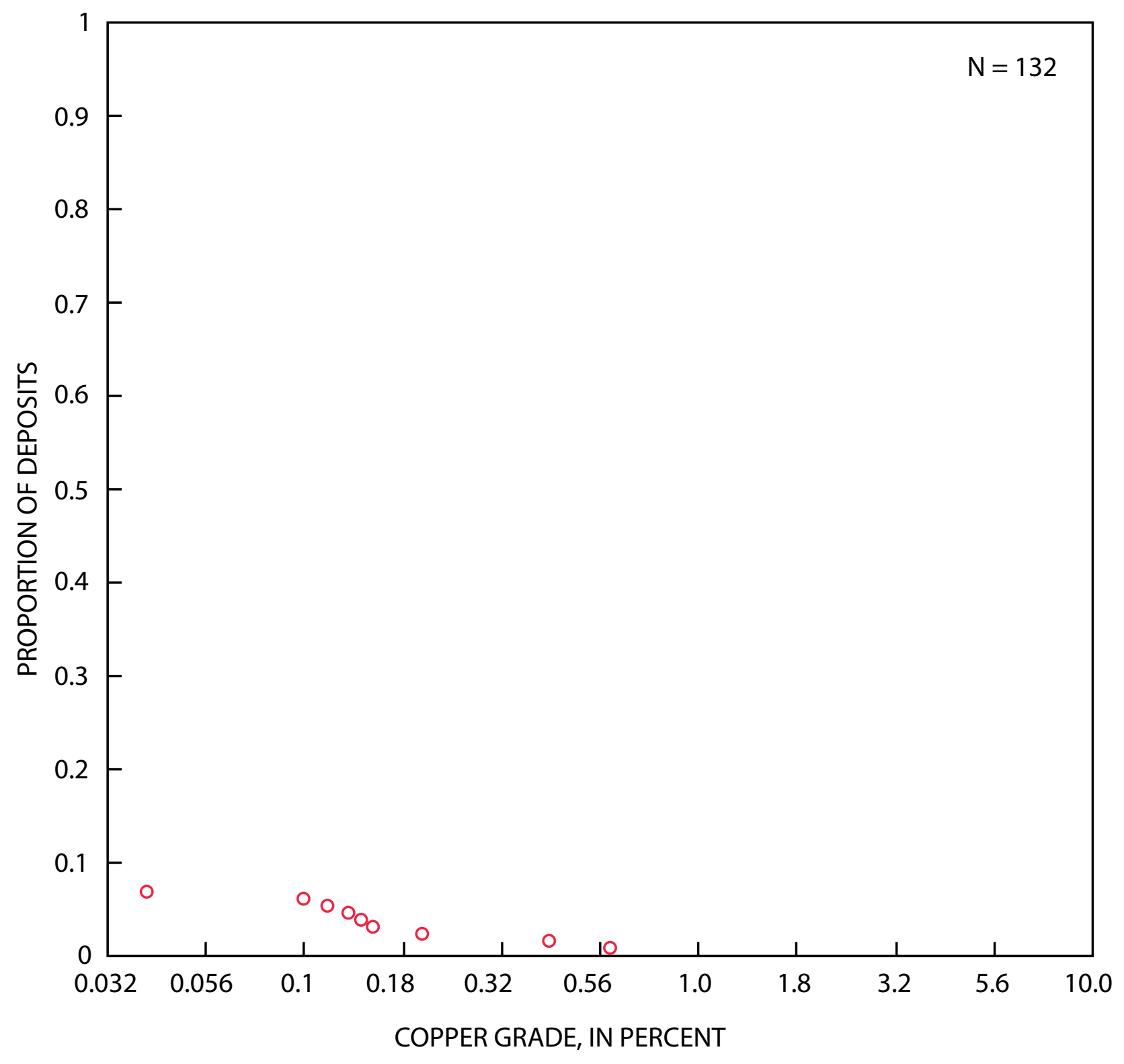

Figure 4. Cumulative frequency of average copper grade of carbonate-hosted amagmatic zinc-lead (CAam) deposits. Each circle represents an individual deposit. 


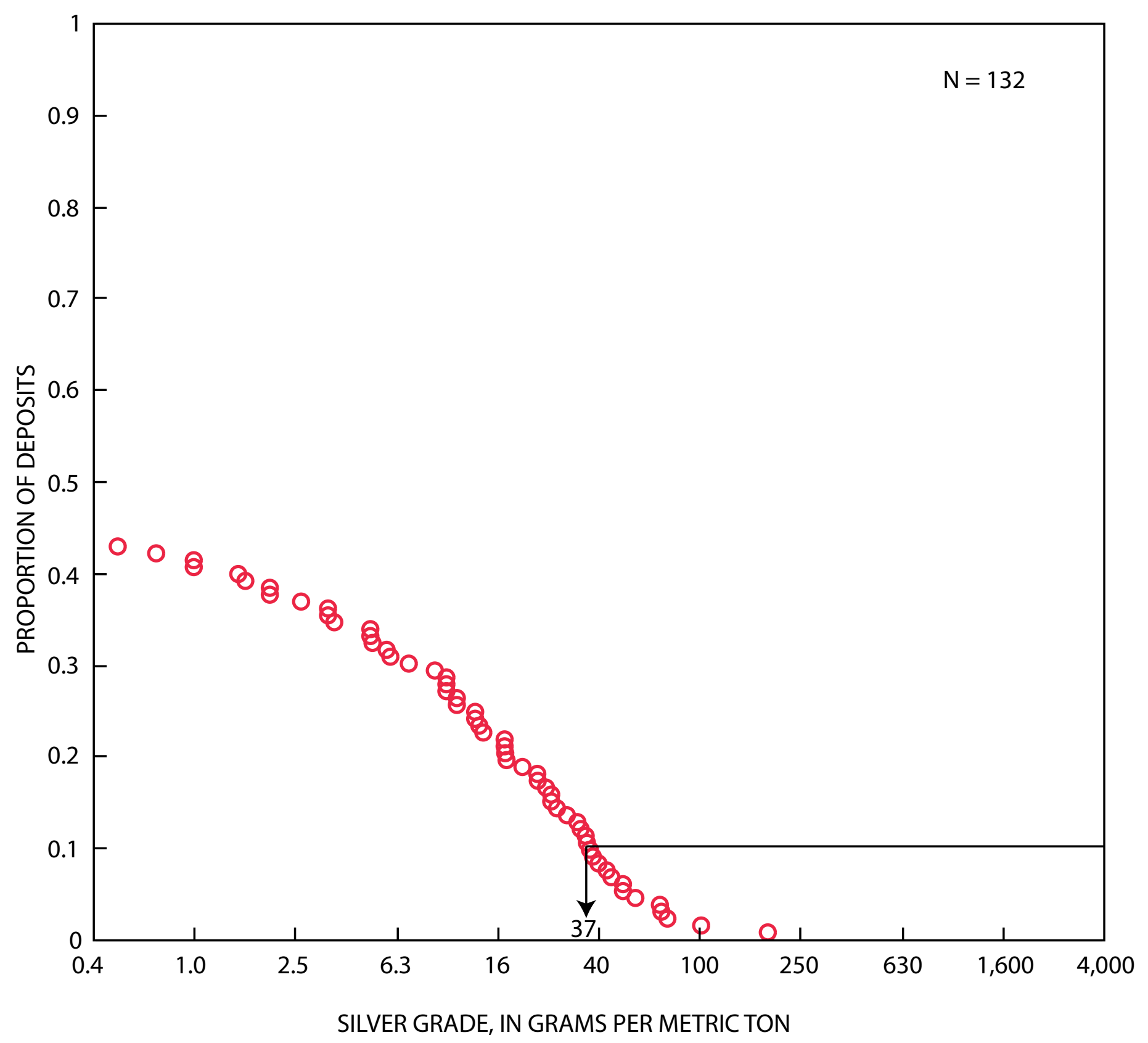

Figure 5. Cumulative frequency of average silver grade of carbonate-hosted amagmatic zinc-lead (CAam) deposits. Each circle represents an individual deposit. Intercept sfor the 10th percentile of the observed distribution is provided. 


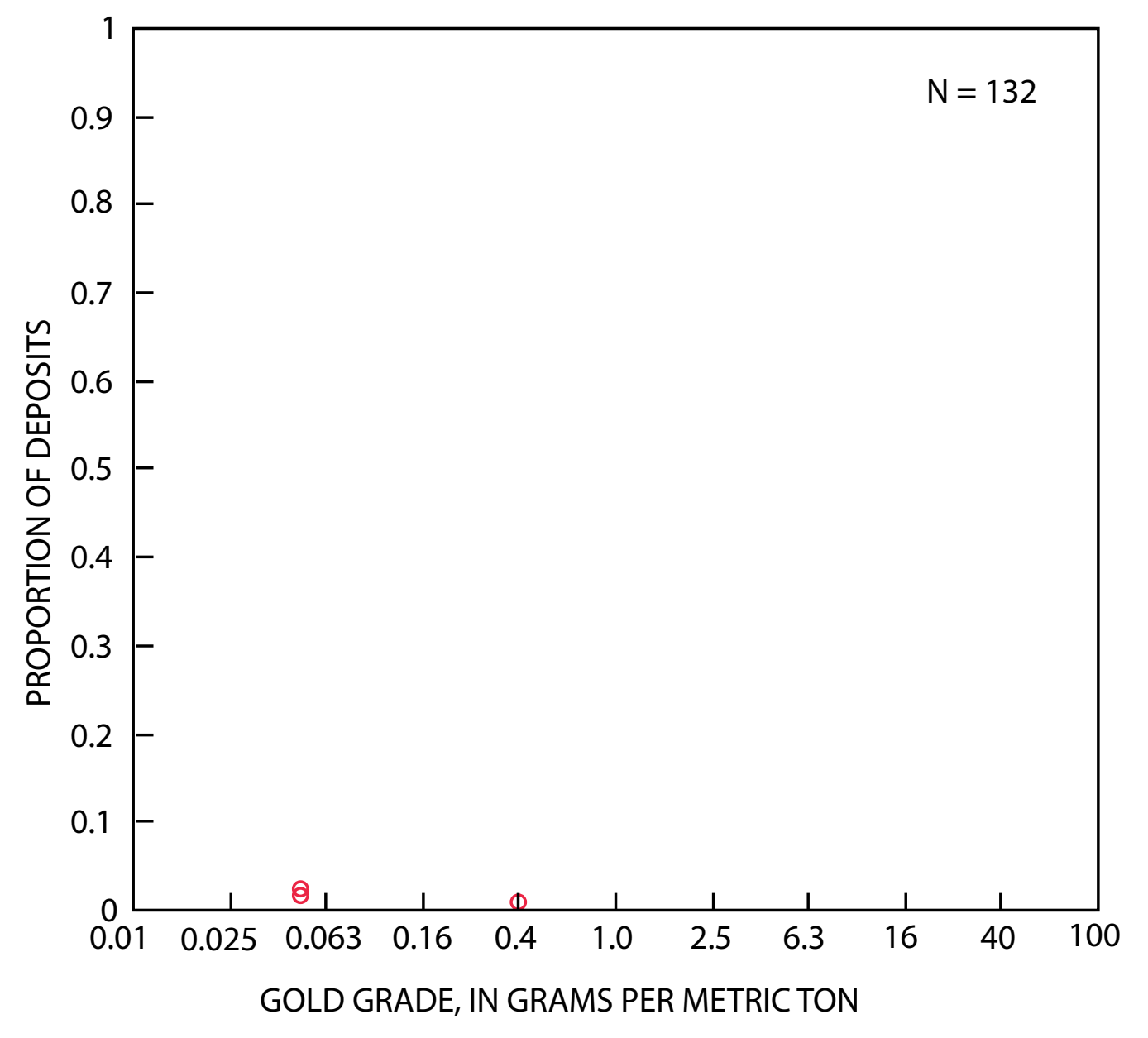

Figure 6. Cumulative frequency of average gold grade of carbonate-hosted amagmatic zinc-lead (CAam) deposits. Each circle represents an individual deposit. 


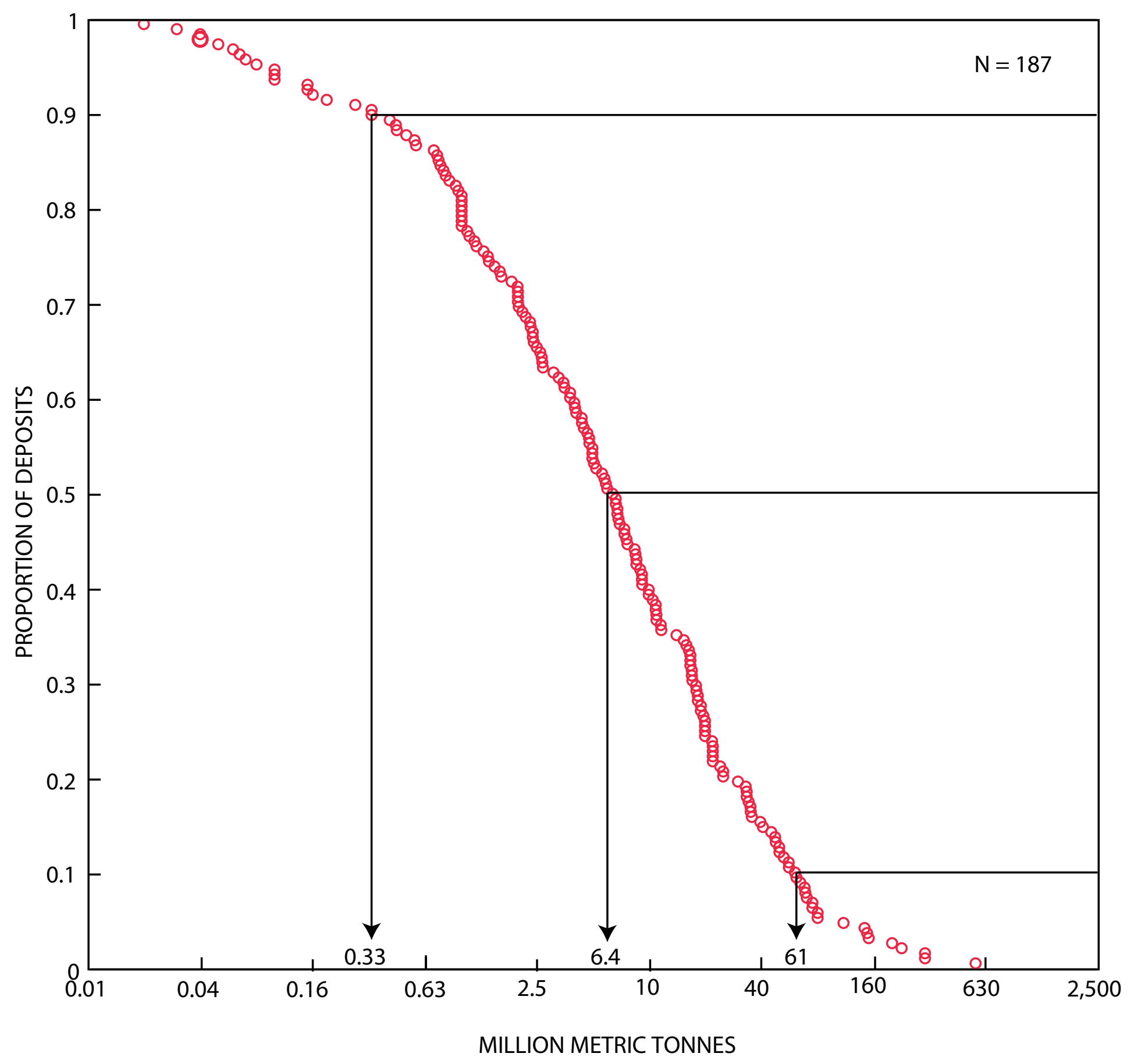

Figure 7. Cumulative frequency of ore tonnage of carbonate-hosted igneous-related zinc-lead (CAig) deposits. Each circle represents an individual deposit. Intercepts for the 90th, 50th, and 10th percentiles of the observed distribution are provided. 


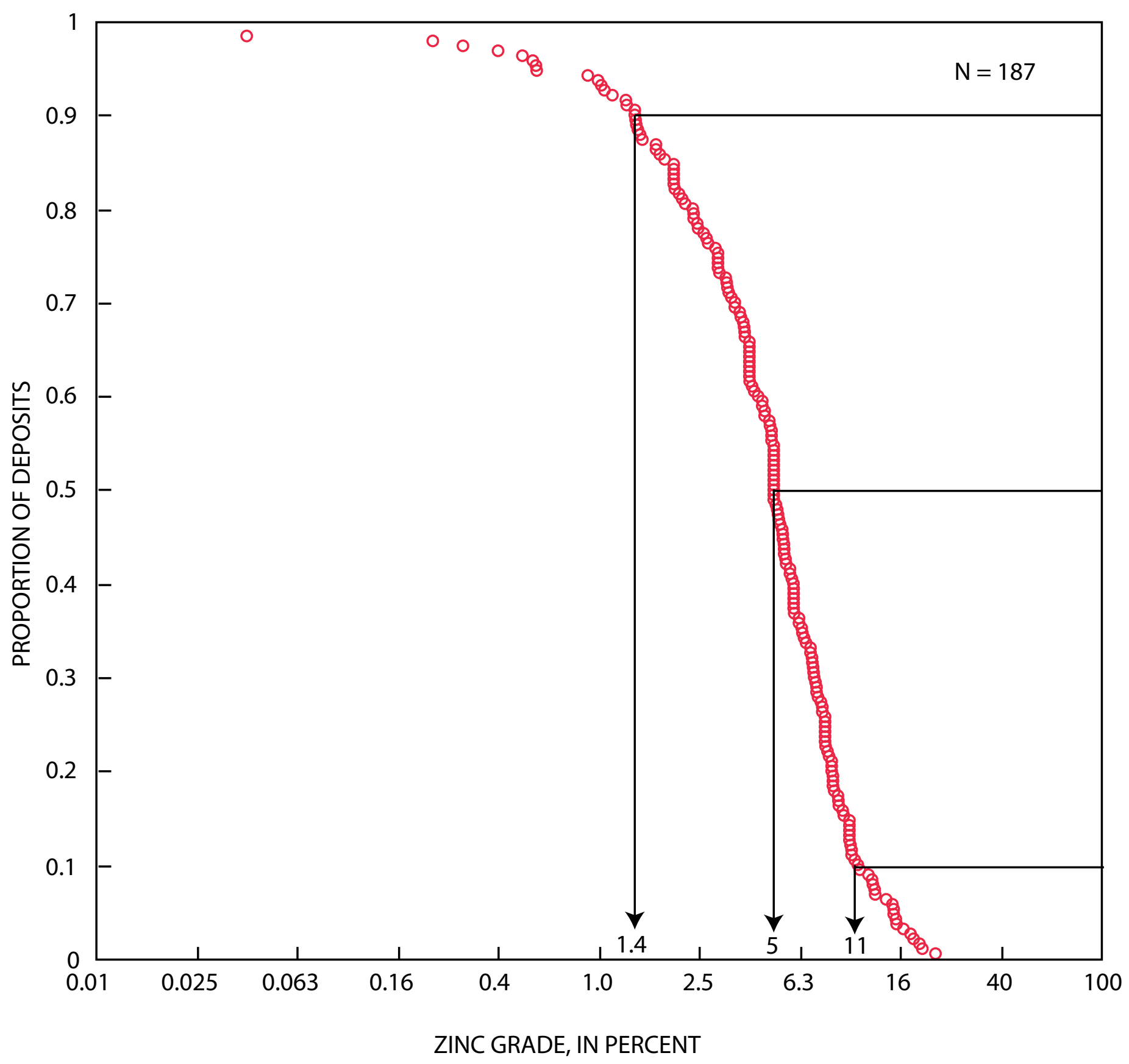

Figure 8. Cumulative frequency of average zinc grade of carbonate-hosted igneous-related zinc-lead (CAig) deposits. Each circle represents an individual deposit. Intercepts for the 90th, 50th, and 10th percentiles of the observed distribution are provided. 


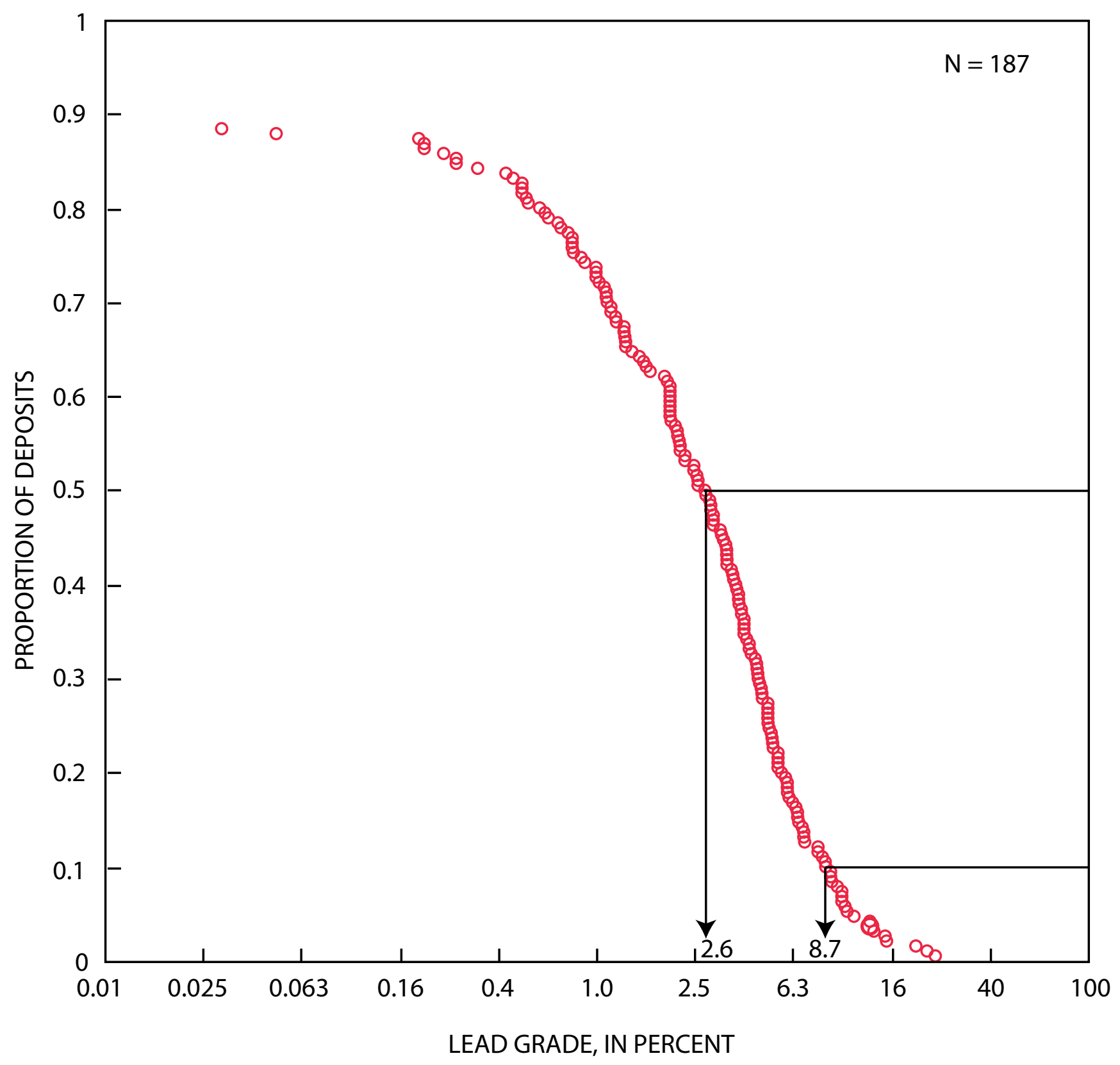

Figure 9. Cumulative frequency of average lead grade of carbonate-hosted igneous-related zinc-lead (CAig) deposits. Each circle represents an individual deposit. Intercepts for the 50th and 10th percentiles of the observed distribution are provided. 


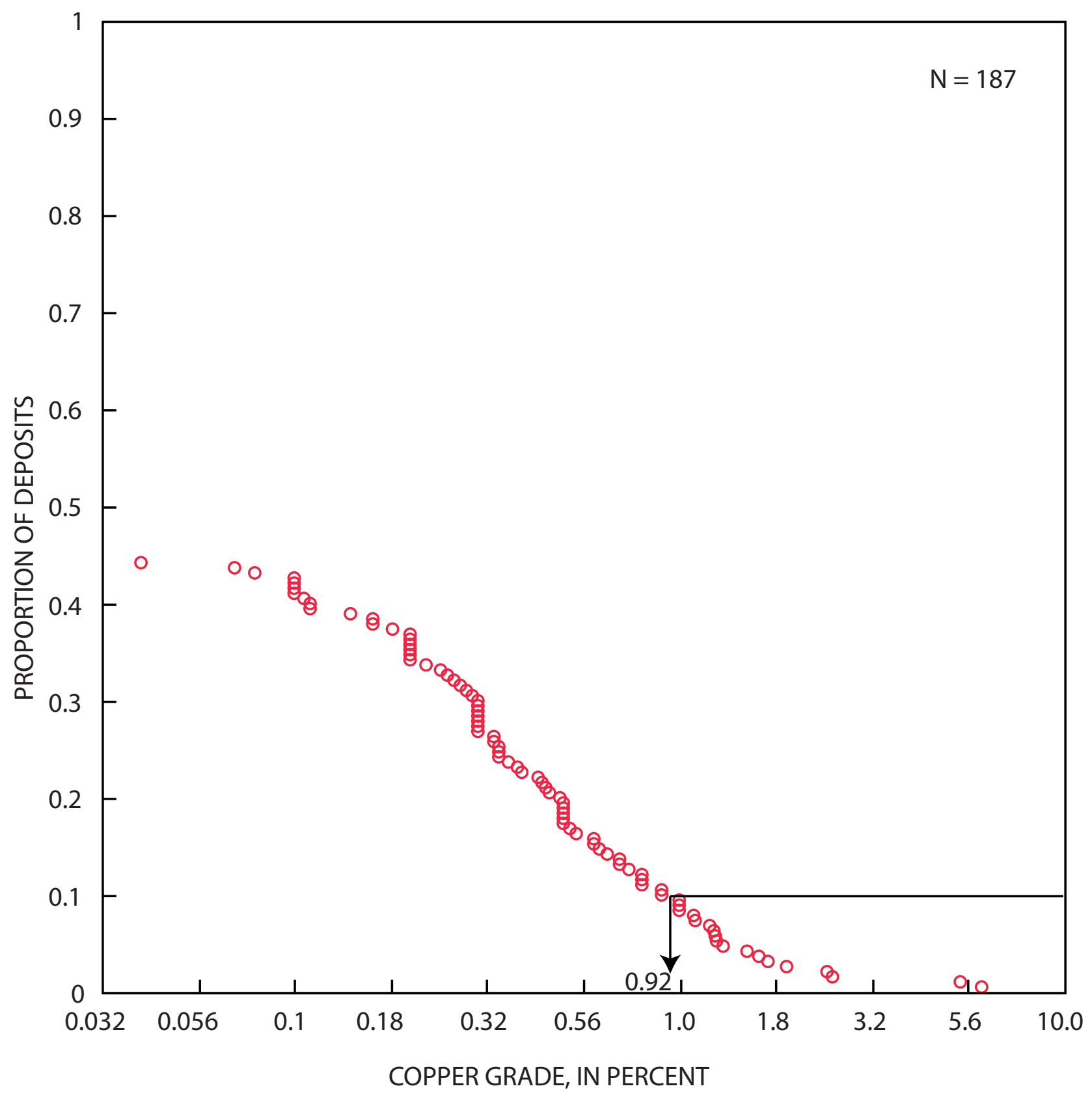

Figure 10. Cumulative frequency of average copper grade of carbonate-hosted igneous-related zinc-lead (CAig) deposits. Each circle represents an individual deposit. Intercept for the 10th percentile of the observed distribution is provided. 


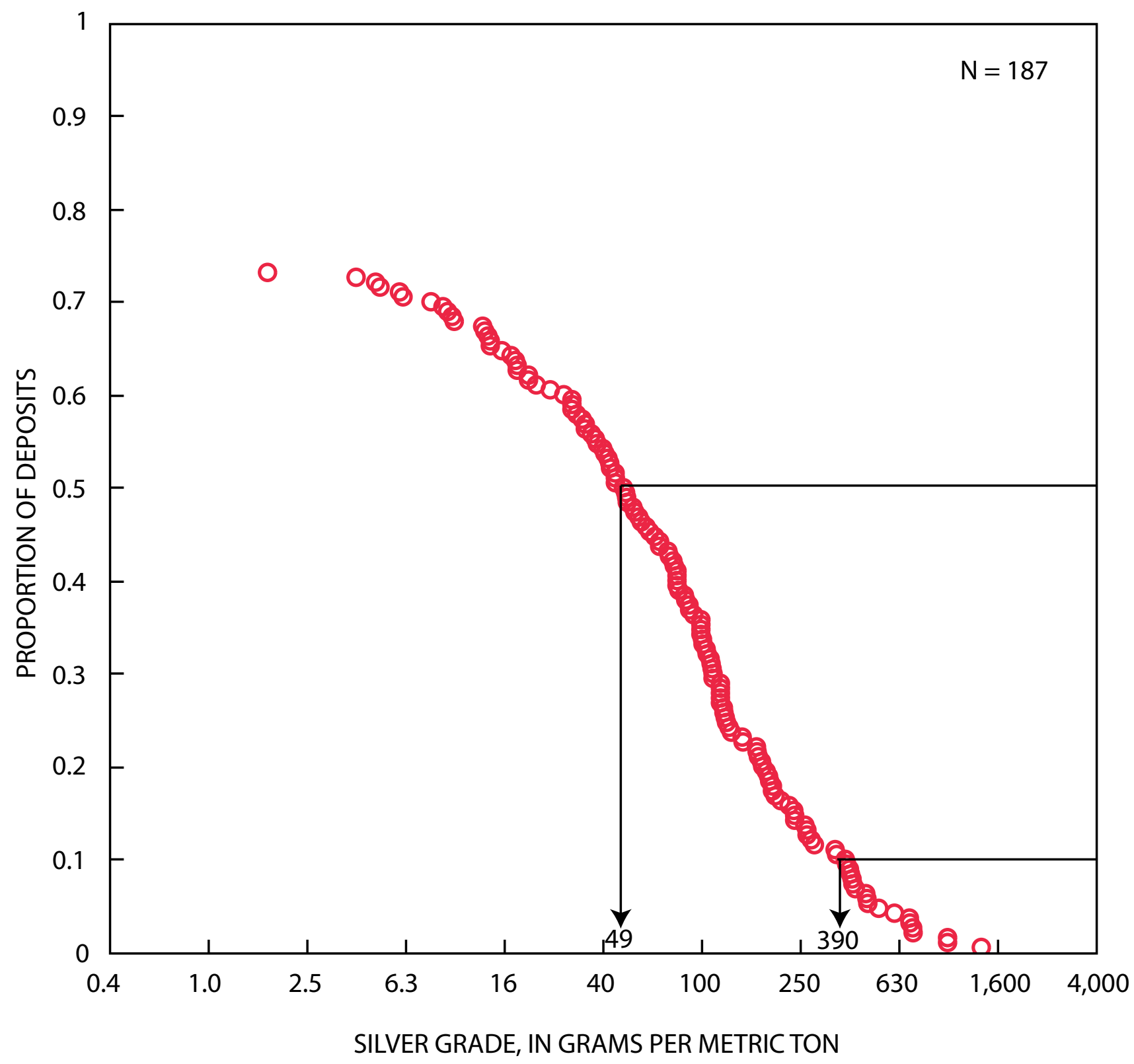

Figure 11. Cumulative frequency of average silver grade of carbonate-hosted igneous-related zinc-lead (CAig) deposits. Each circle represents an individual deposit. Intercepts for the 50th and 10th percentiles of the observed distribution are provided. 


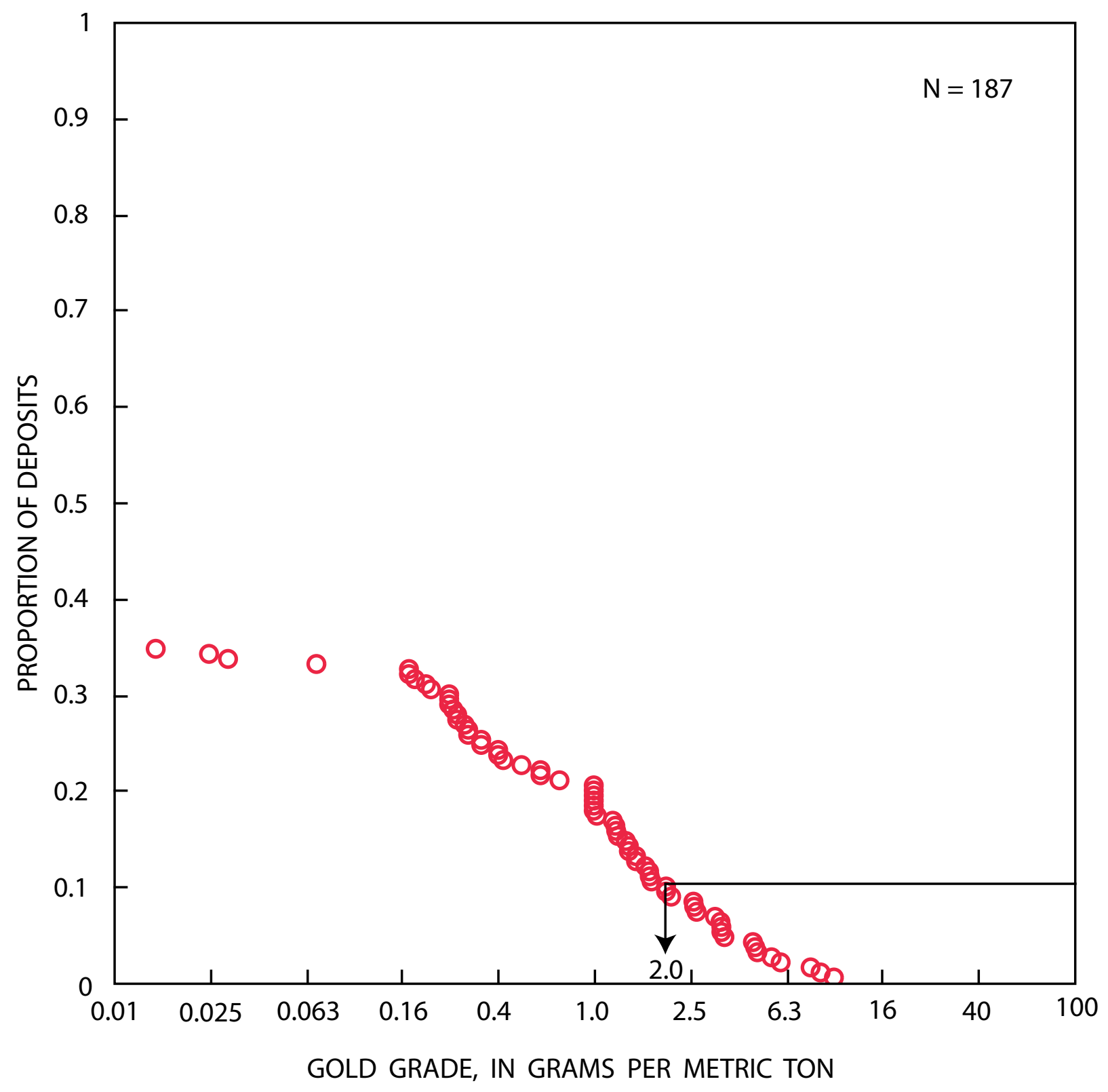

Figure 12. Cumulative frequency of average gold grade of carbonate-hosted igneous-related zinc-lead (CAig) deposits. Each circle represents an individual deposit. Intercept for the 10th percentile of the observed distribution is provided. 


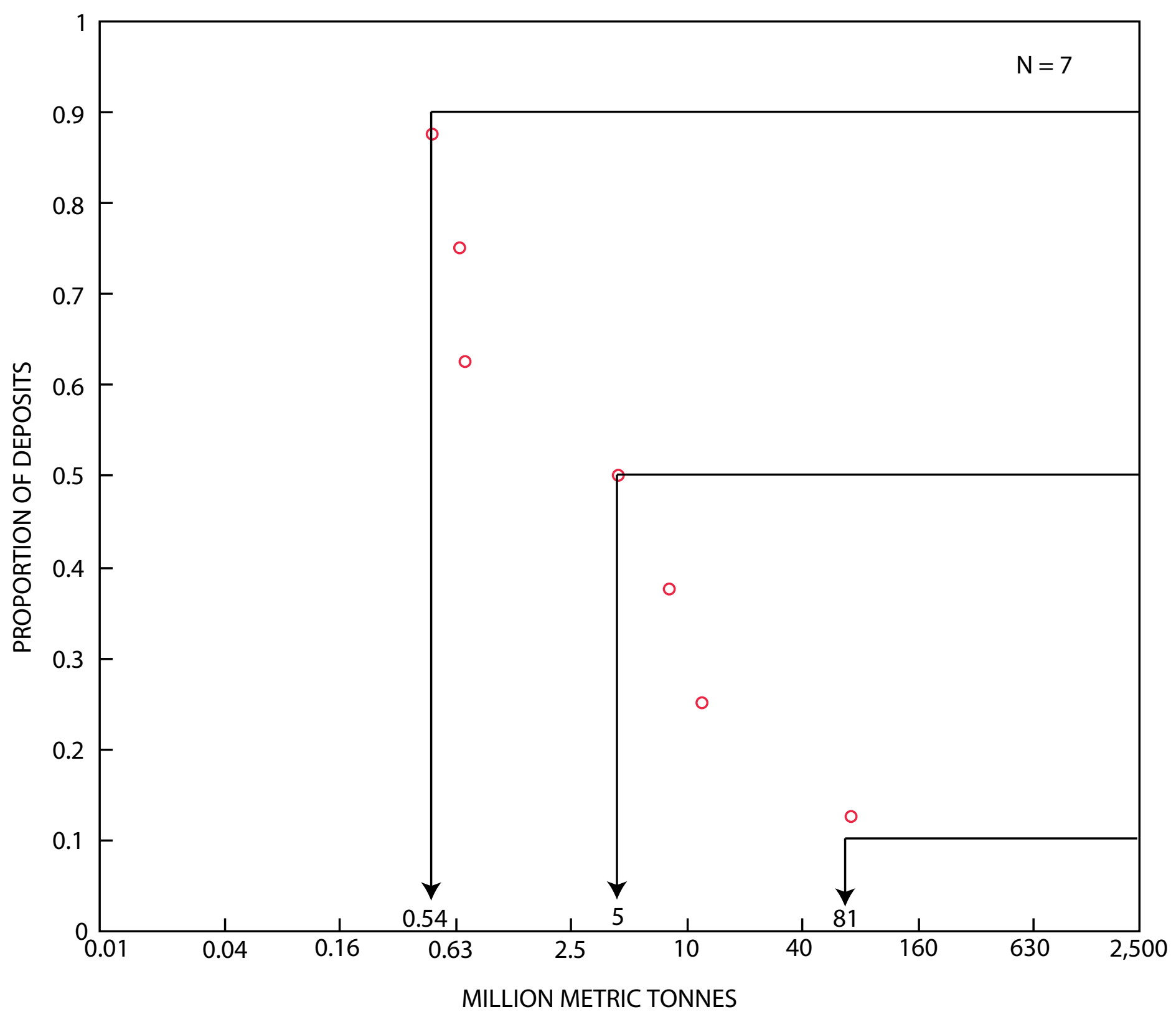

Figure 13. Cumulative frequency of ore tonnage of carbonate-hosted metamorphosed zinc-lead (CAme) deposits. Each circle represents an individual deposit. Intercepts for the 90th, 50th, and 10th percentiles of the observed distribution are provided. 


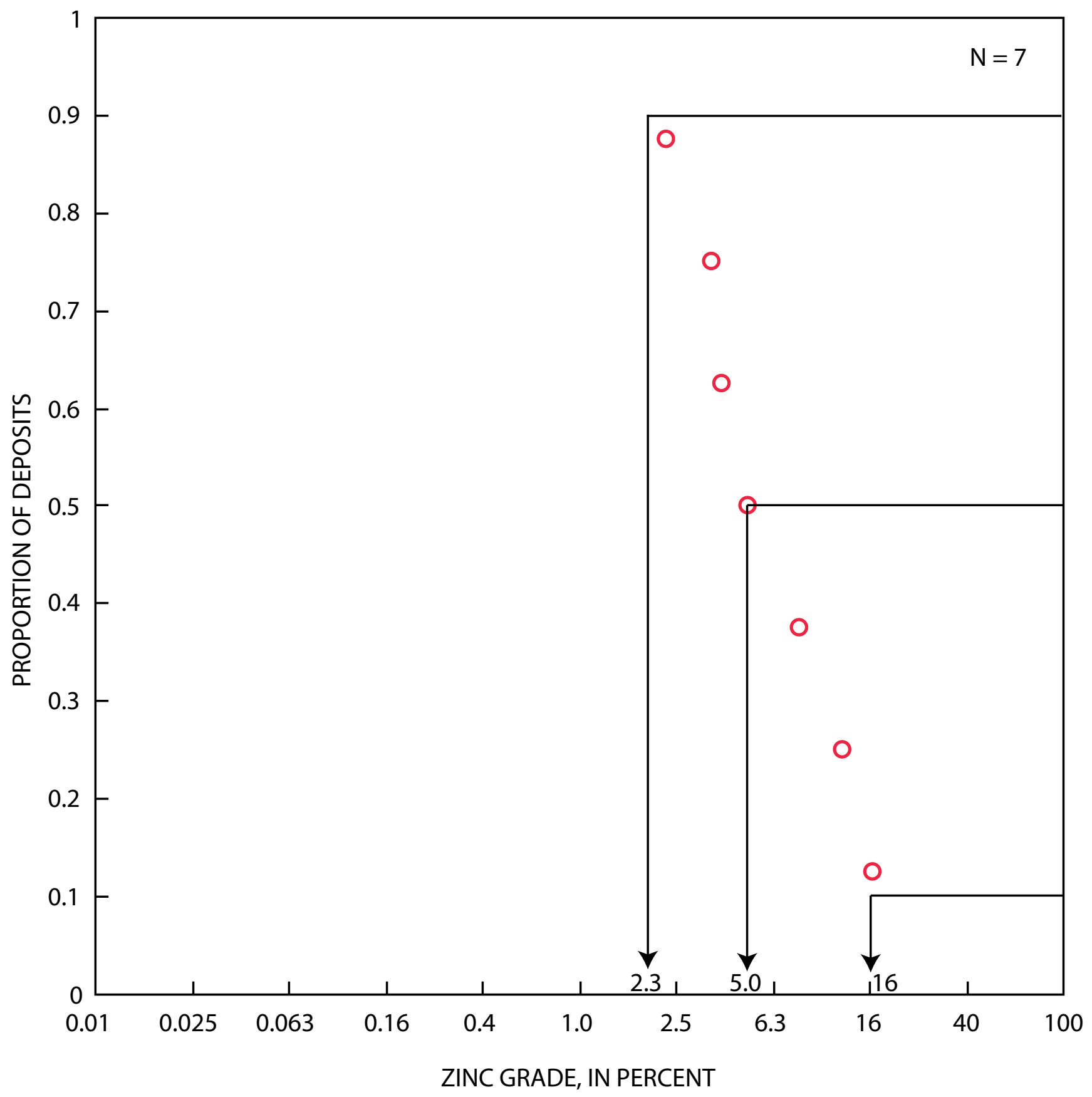

Figure 14. Cumulative frequency of average zinc grade of carbonate-hosted metamorphosed zinc-lead (CAme) deposits. Each circle represents an individual deposit. Intercepts for the 90th, 50th, and 10th percentiles of the observed distribution are provided. 


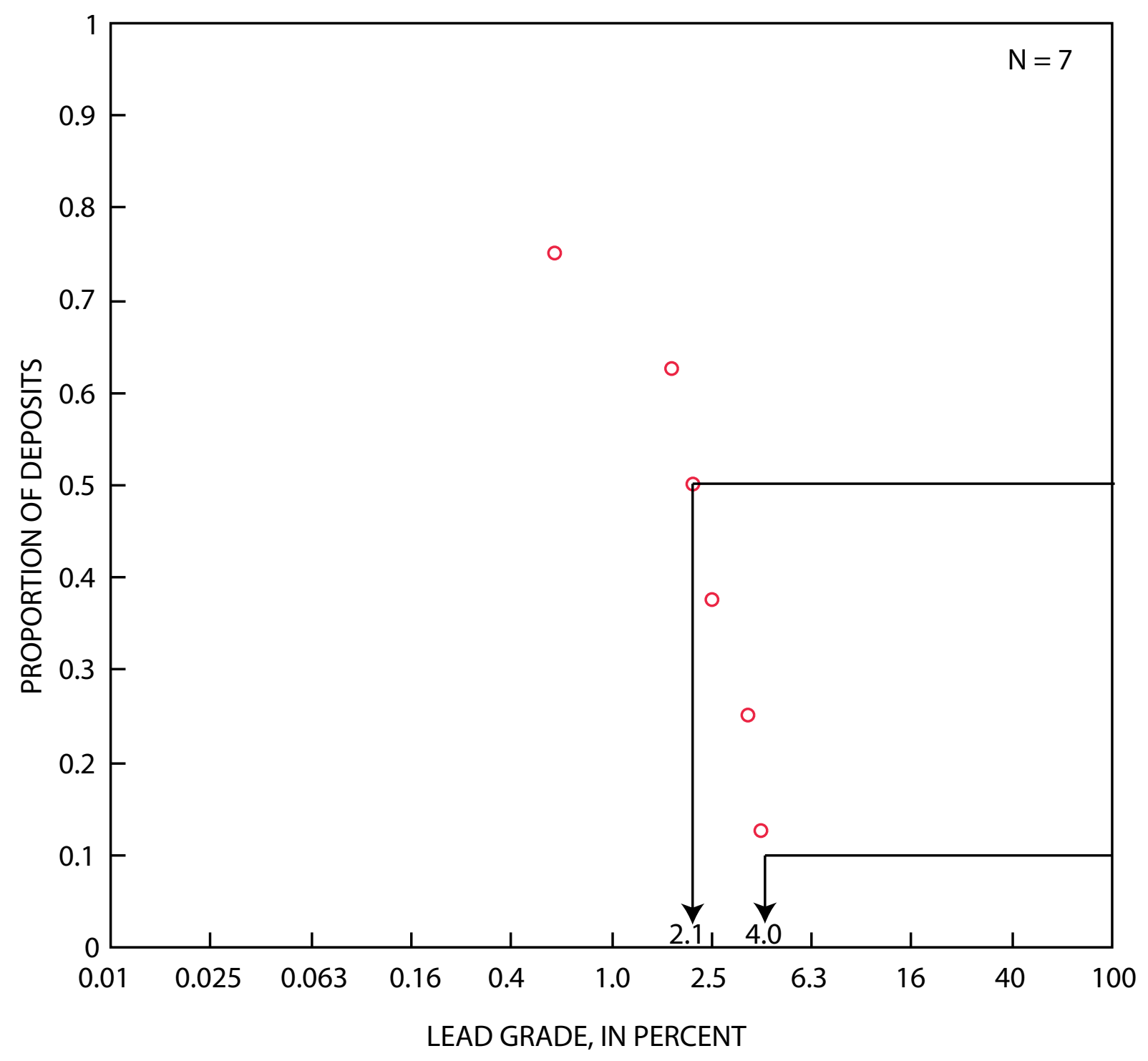

Figure 15. Cumulative frequency of average lead grade of carbonate-hosted metamorphosed zinc-lead (CAme) deposits. Each circle represents an individual deposit. Intercepts for the 50th and 10th percentiles of the observed distribution are provided. 


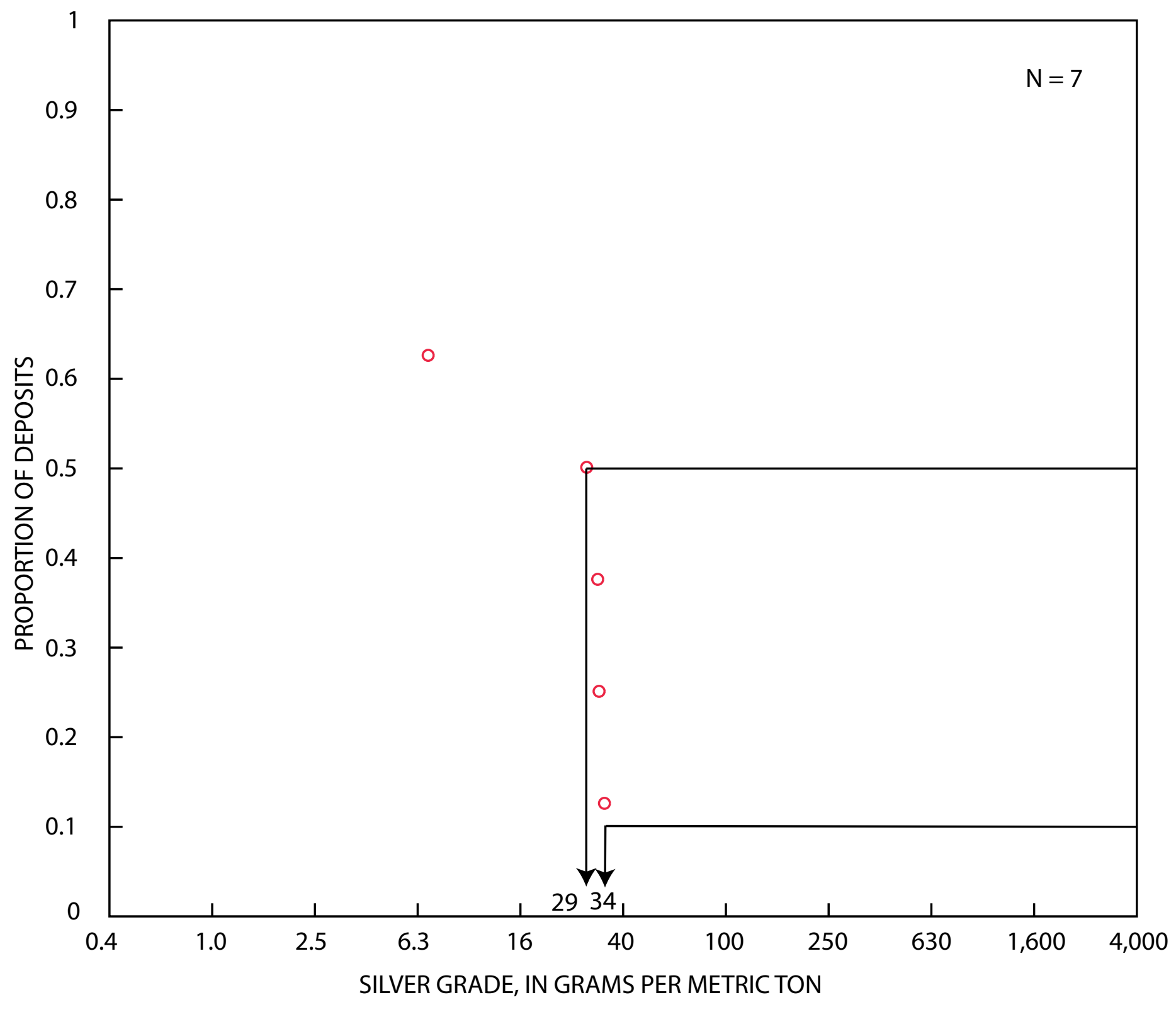

Figure 16. Cumulative frequency of average silver grade of carbonate-hosted metamorphosed zinc-lead (CAme) deposits. Each circle represents an individual deposit. Intercepts for the 90th, 50th, and 10th percentiles of the observed distribution are provided 


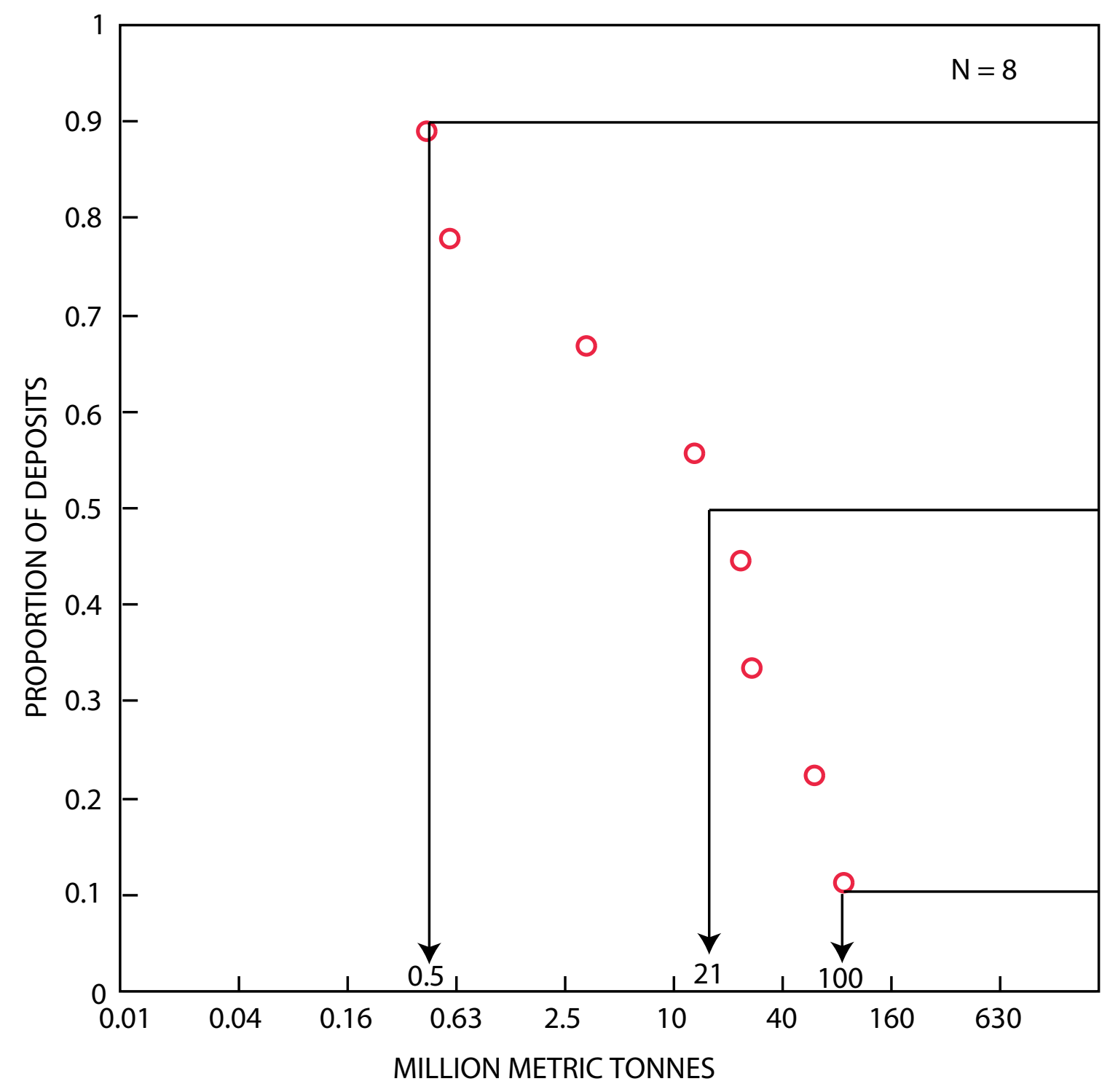

Figure 17. Cumulative frequency of ore tonnage of Kipushi deposits. Each circle represents an individual deposit. Intercepts for the 90th, 50th, and 10th percentiles of the observed distribution are provided 


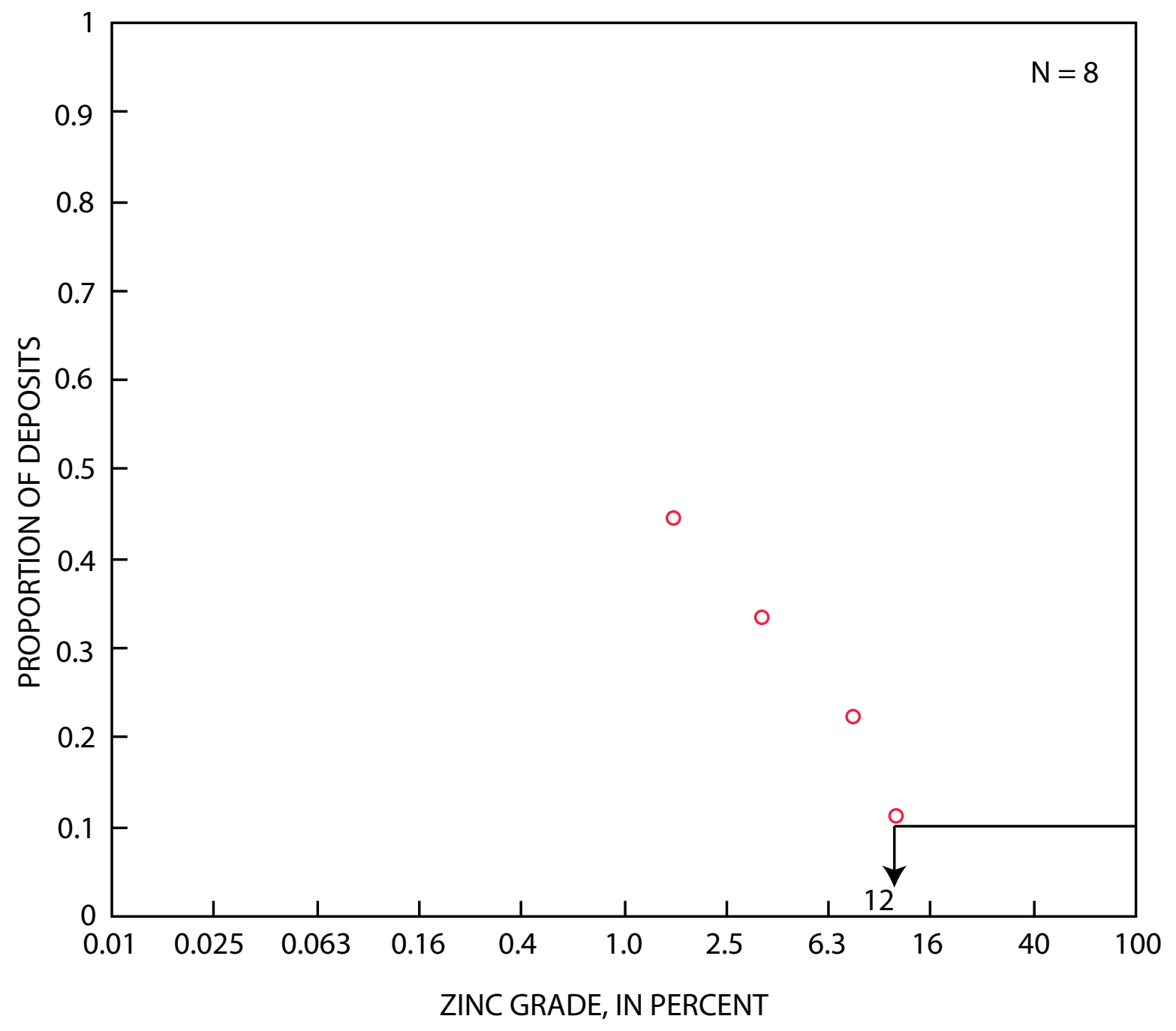

Figure 18. Cumulative frequency of average zinc grades of Kipushi deposits. Each circle represents an individual deposit. Intercept for the 10th percentile of the observed distribution is provided 


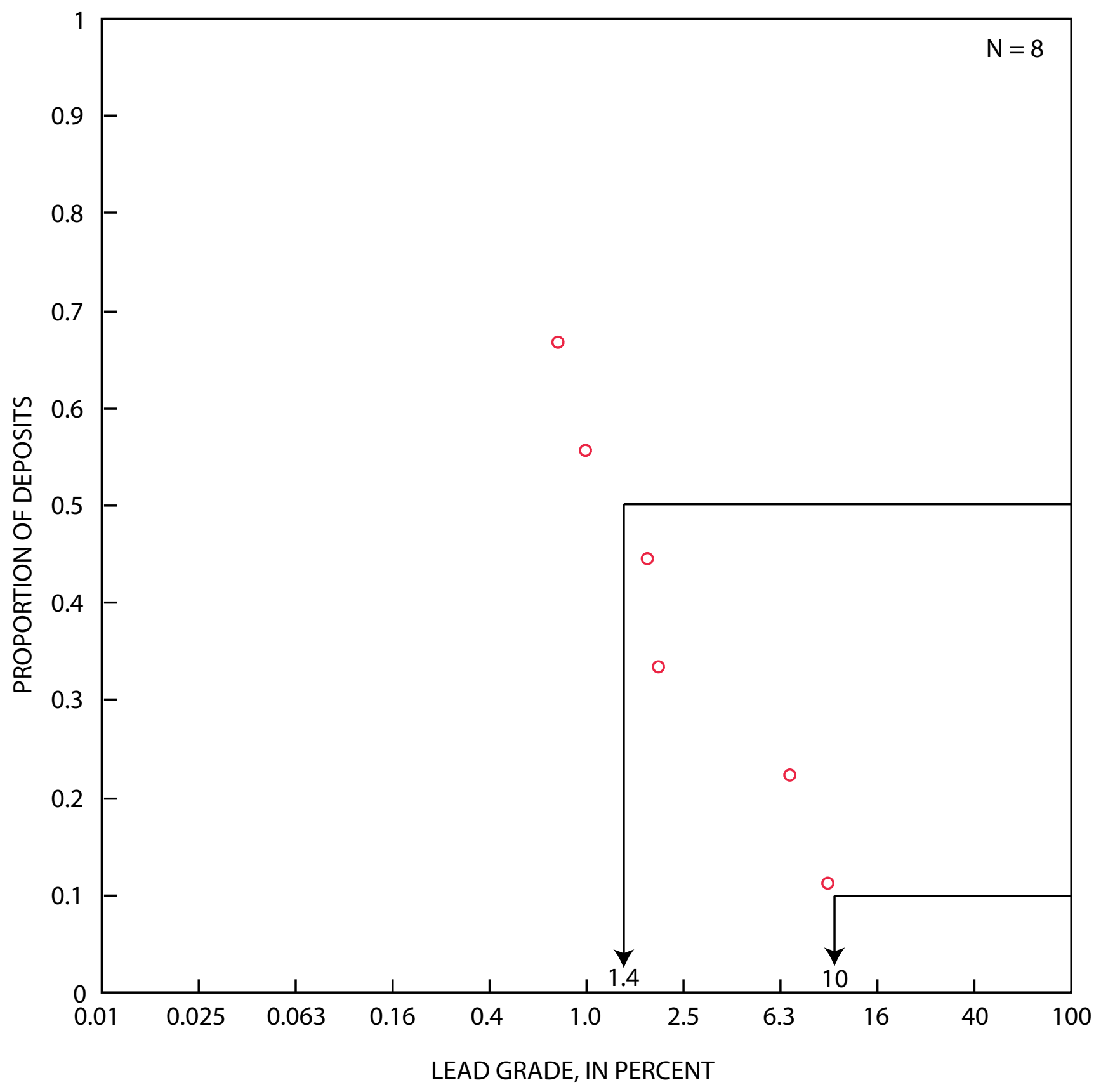

Figure 19. Cumulative frequency of average lead grades of Kipushi deposits. Each circle represents an individual deposit. Intercepts for the 50th and 10th percentiles of the observed distribution are provided 


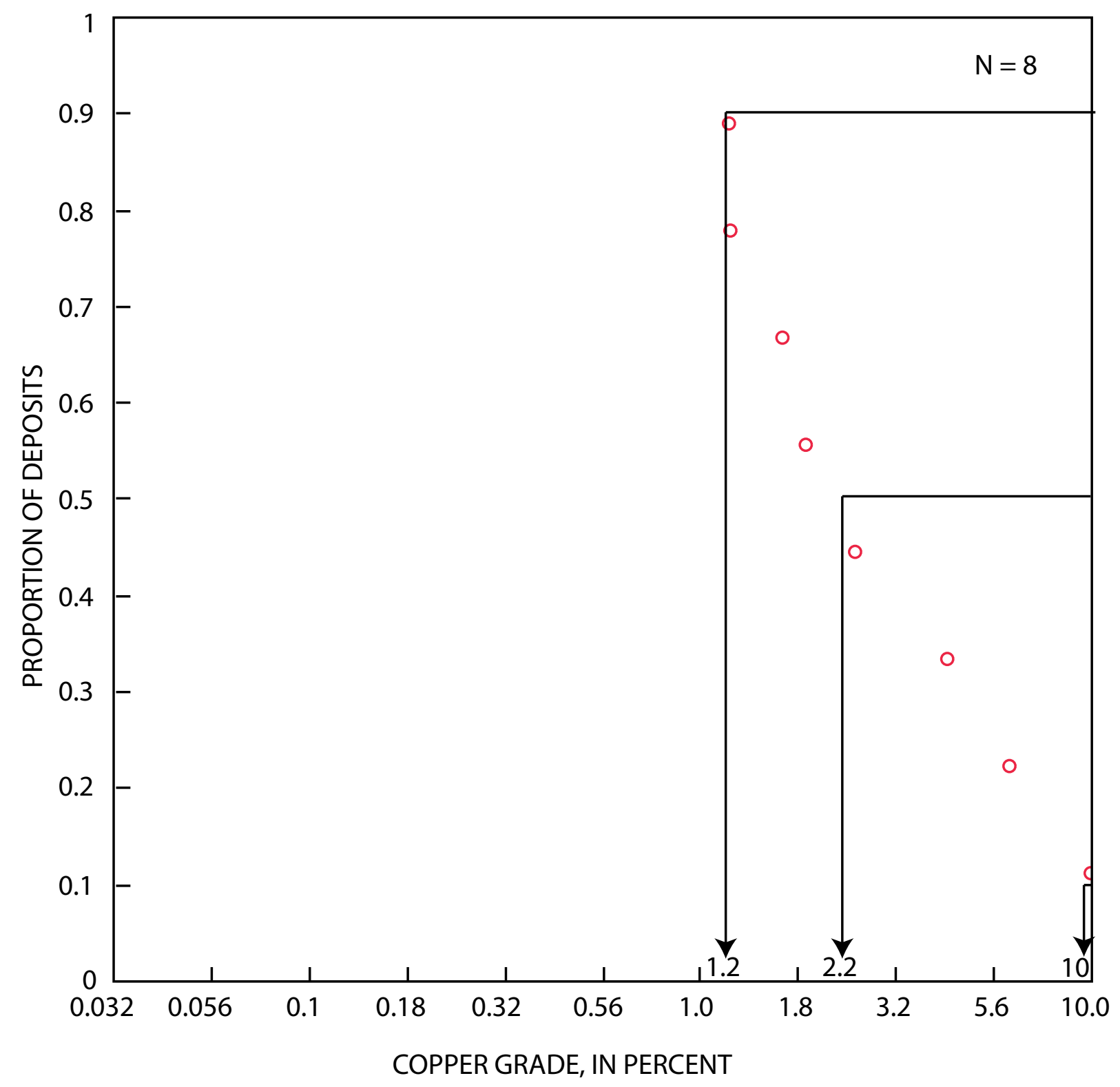

Figure 20. Cumulative frequency of average copper grades of Kipushi deposits. Each circle represents an individual deposit. Intercepts for the 90th, 50th, and 10th percentiles of the observed distribution are provided 


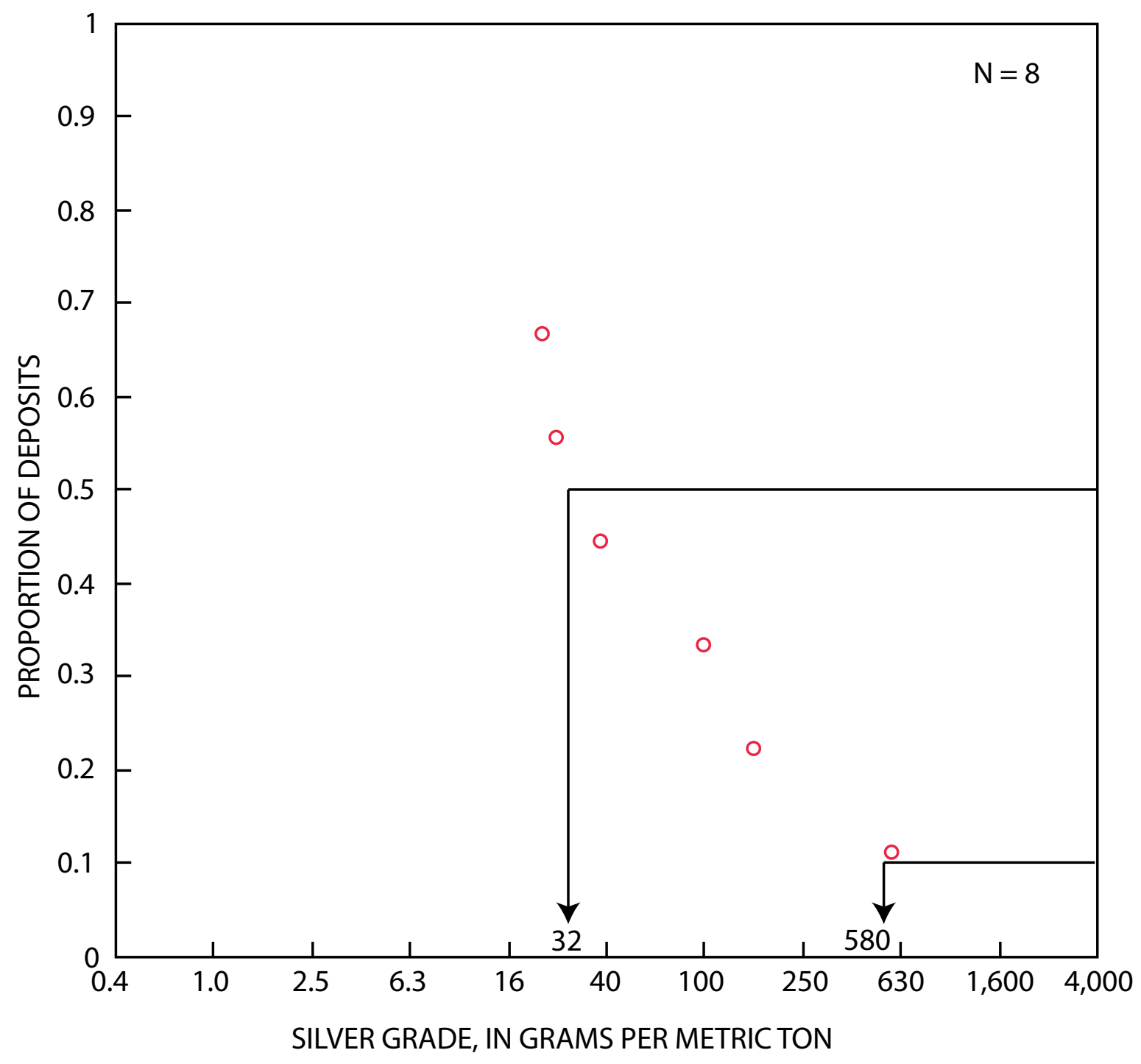

Figure 21. Cumulative frequency of average silver grades of Kipushi deposits. Each circle represents an individual deposit. Intercepts for the 50th and 10th percentiles of the observed distribution are provided 


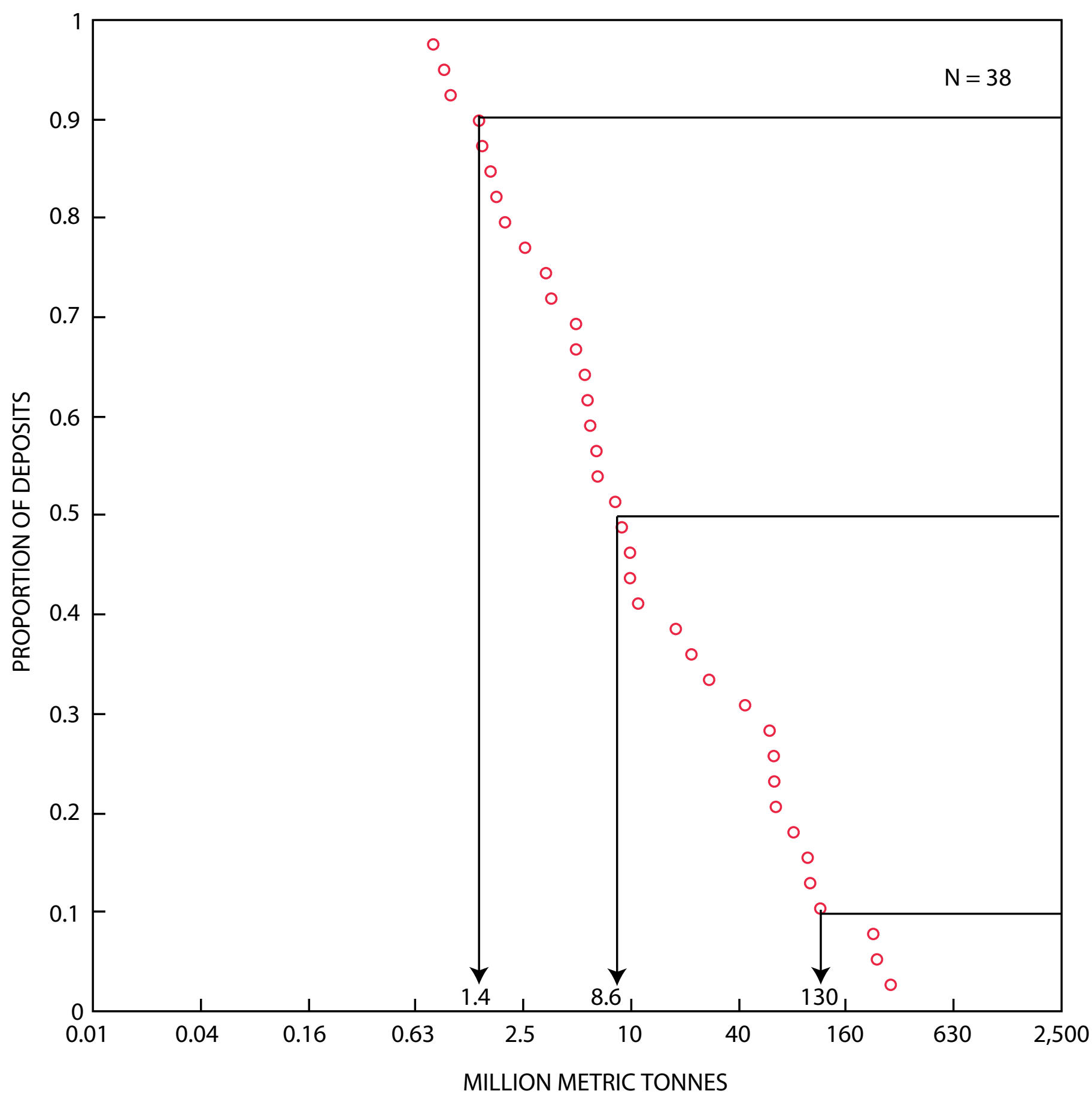

Figure 22. Cumulative frequency of ore tonnage of mixed lithology igneous-related zinc-lead (MLig) deposits. Each circle represents an individual deposit. Intercepts for the 90th, 50th, and 10th percentiles of the observed distribution are provided 


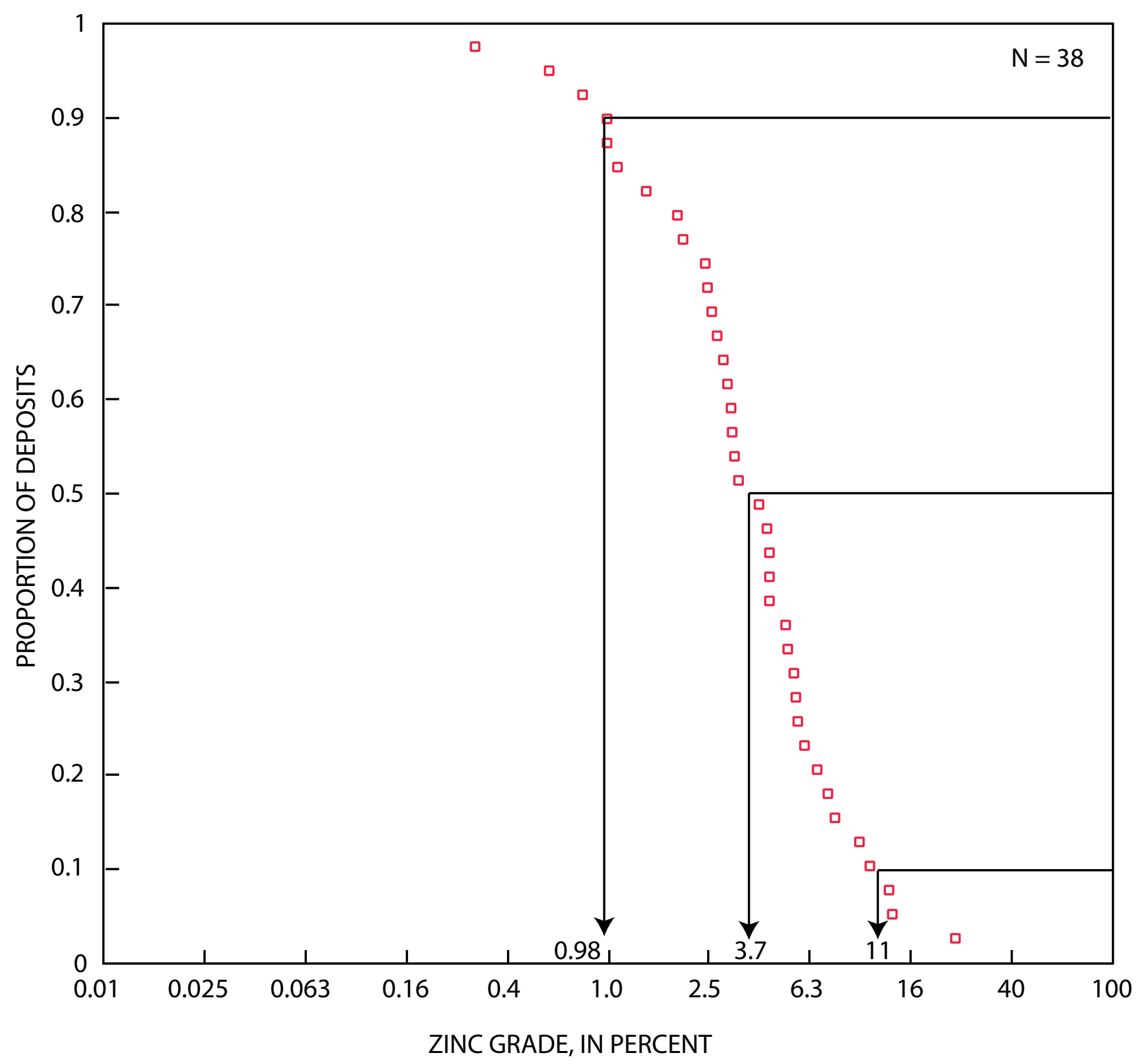

Figure 23. Cumulative frequency of average zinc grades of mixed lithology igneous-related zinc-lead (MLig) deposits. Each point represents an individual deposit. Intercepts for the 90th, 50th, and 10th percentiles of the observed distribution are provided 


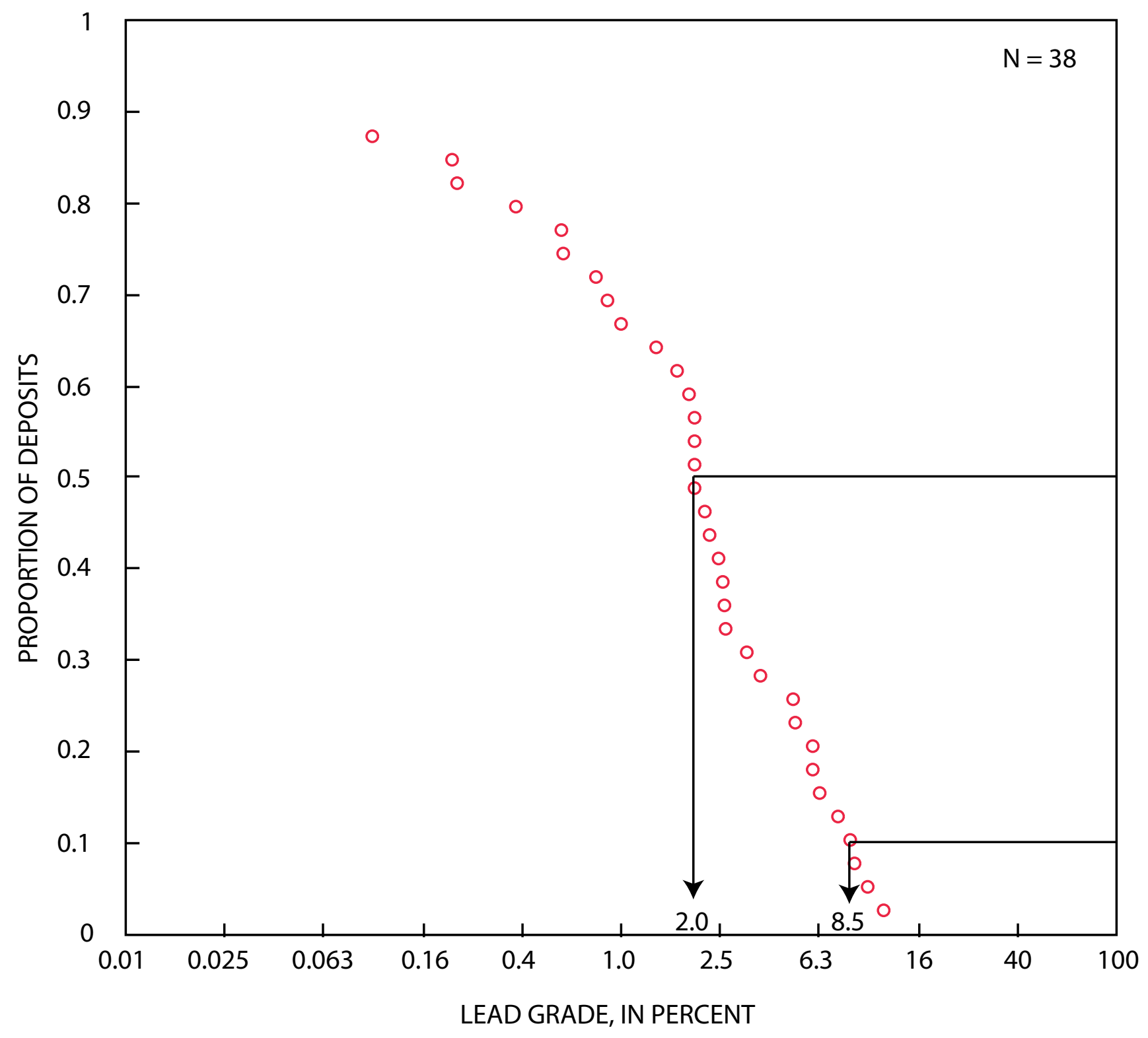

Figure 24. Cumulative frequency of average lead grades of mixed lithology igneous-related zinc-lead (MLig) deposits. Each circle represents an individual deposit. Intercepts for the 50th and 10th percentiles of the observed distribution are provided 


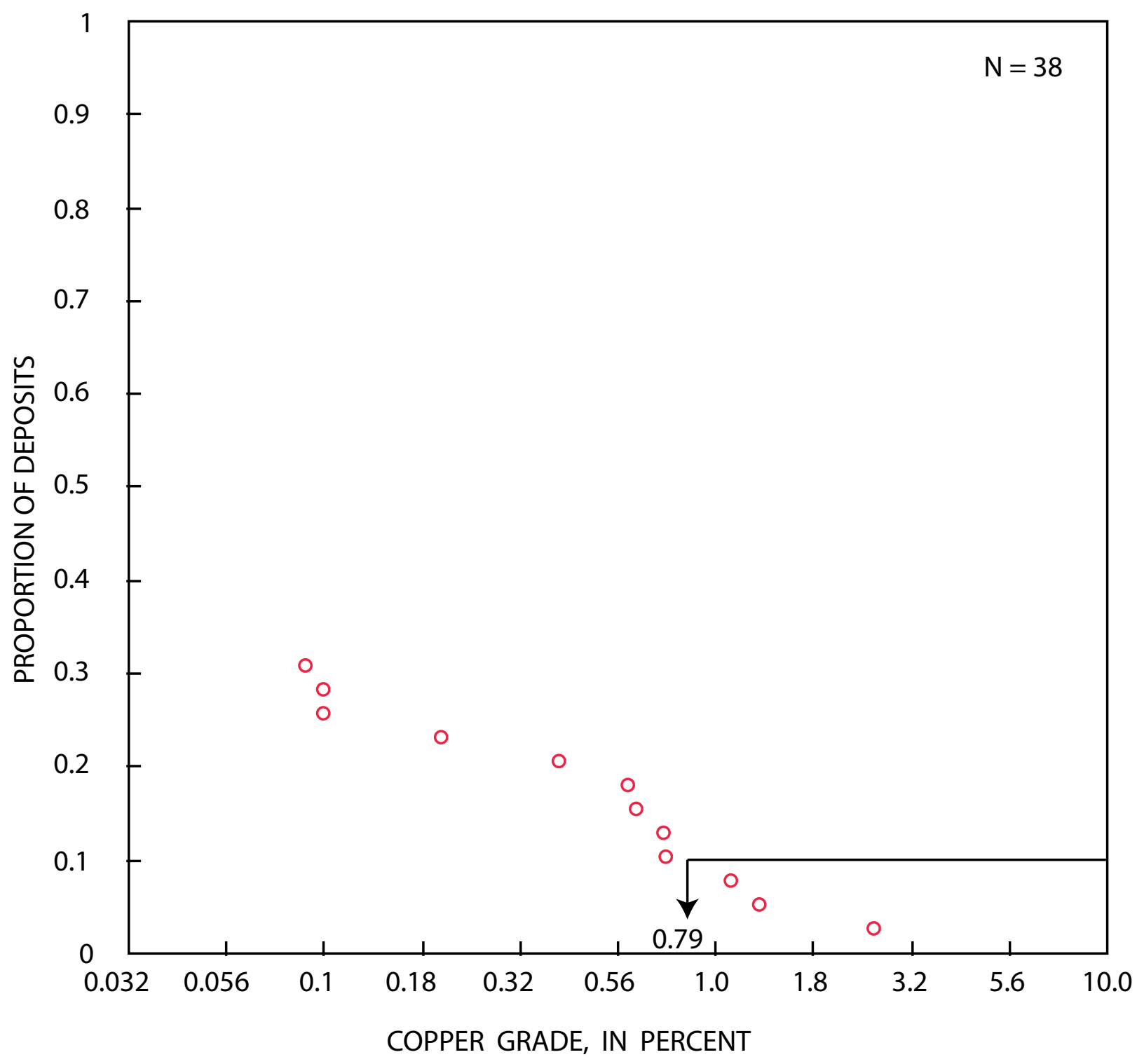

Figure 25. Cumulative frequency of average copper grades of mixed lithology igneous-related zinc-lead (MLig) deposits. Each circle represents an individual deposit. Intercept for the 10th percentile of the observed distribution is provided 


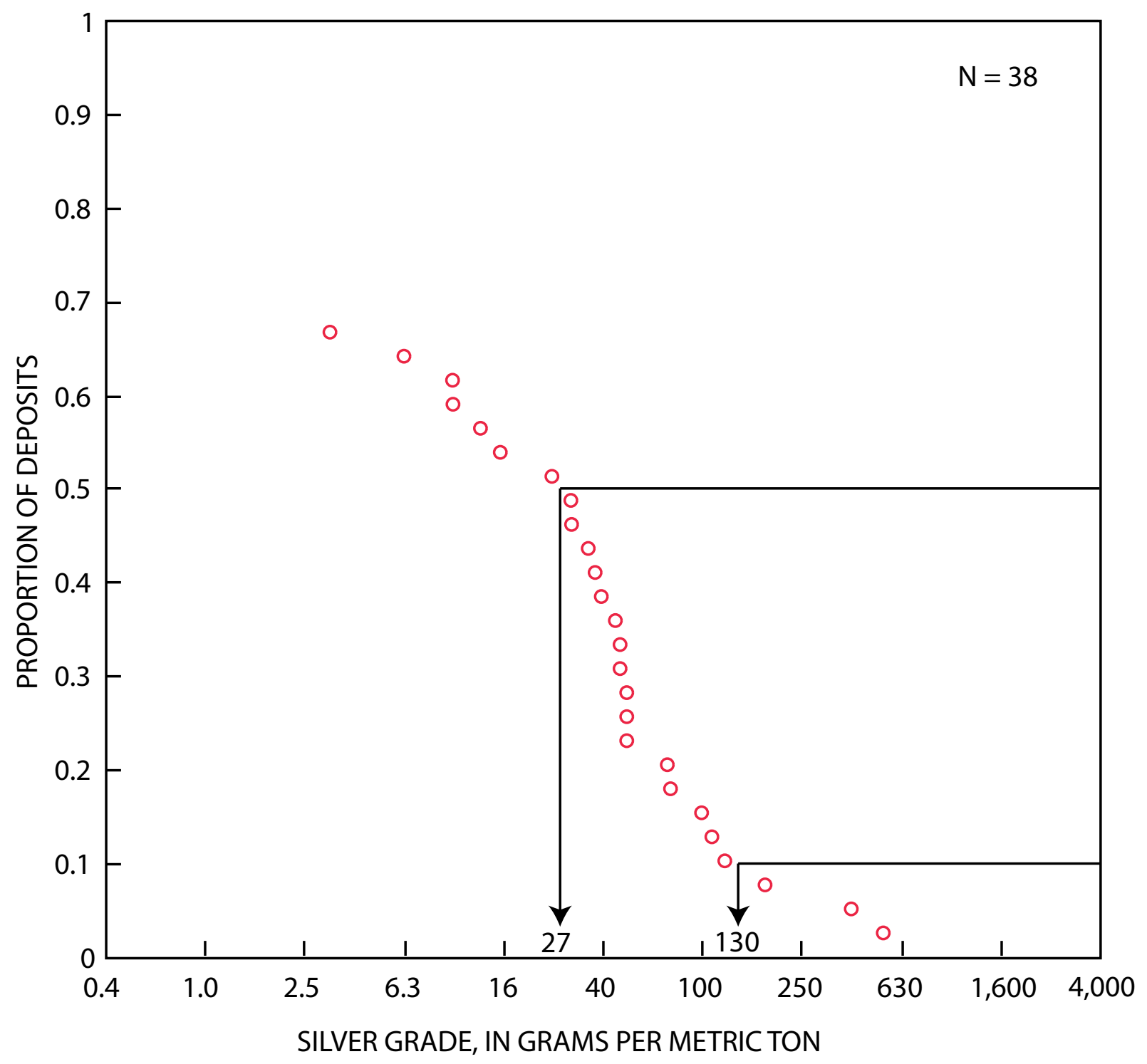

Figure 26. Cumulative frequency of average silver grades of mixed lithology igneous-related zinc-lead (MLig) deposits. Each circle represents an individual deposit. Intercepts for the 50th and 10th percentiles of the observed distribution are provided 


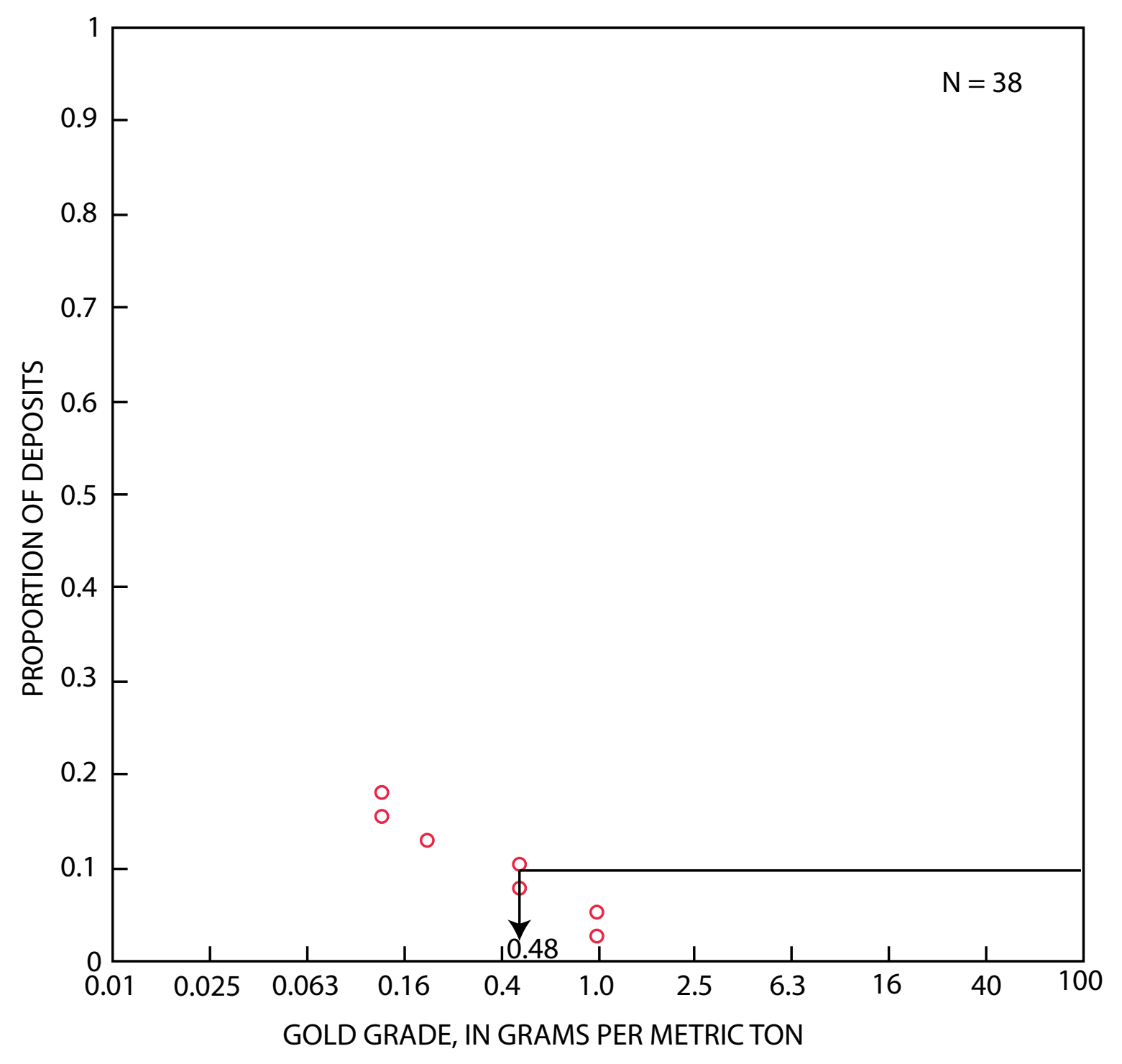

Figure 27. Cumulative frequency of average gold grades of mixed lithology igneous-related zinc-lead (MLig) deposits. Each circle represents an individual deposit. Intercept for the 10th percentile of the observed distribution is provided 


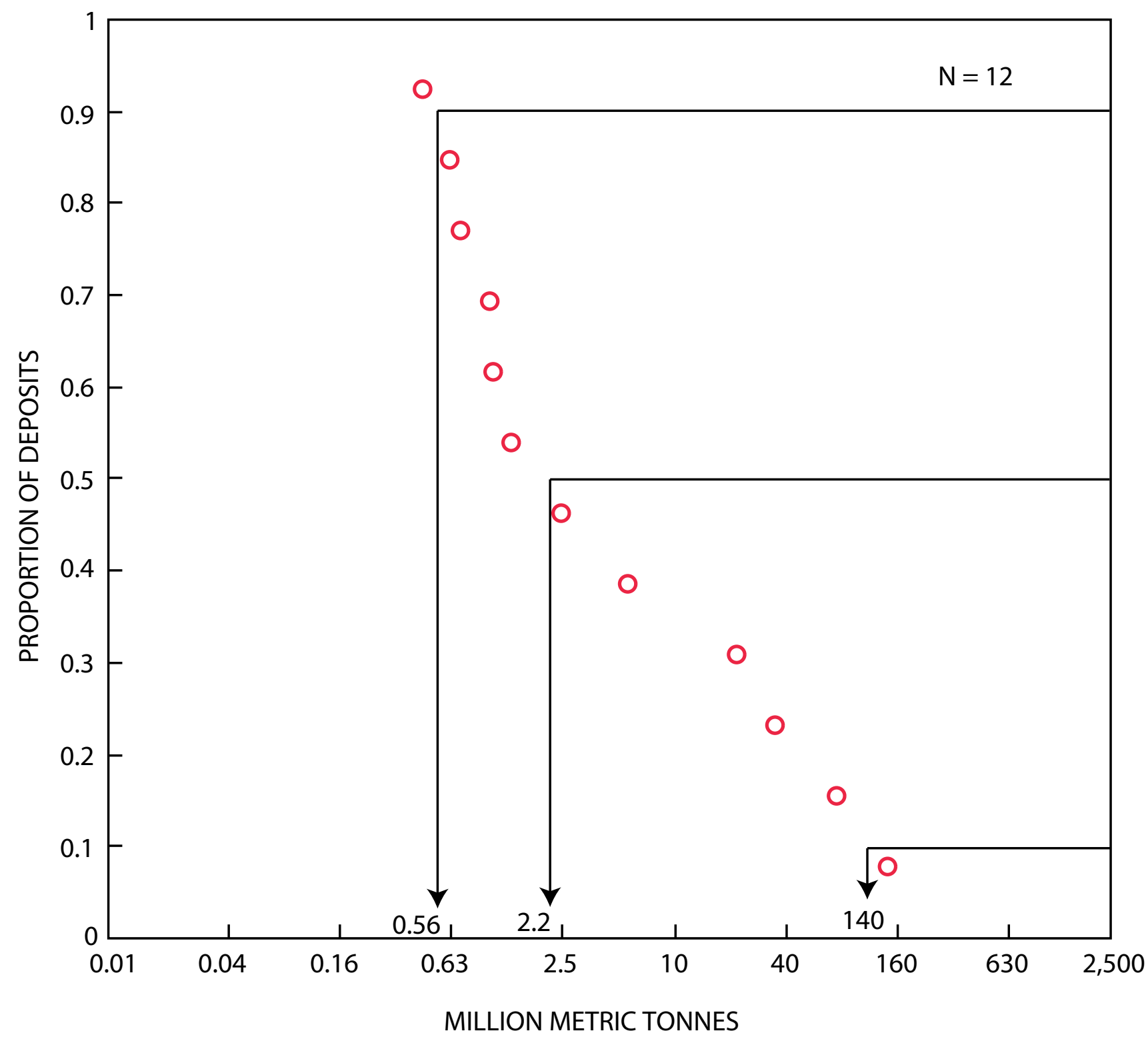

Figure 28. Cumulative frequency of ore tonnage of mixed lithology metamorphosed zinc-lead (MLme) deposits. Each circle represents an individual deposit. Intercepts for the 90th, 50th, and 10th percentiles of the observed distribution are provided 


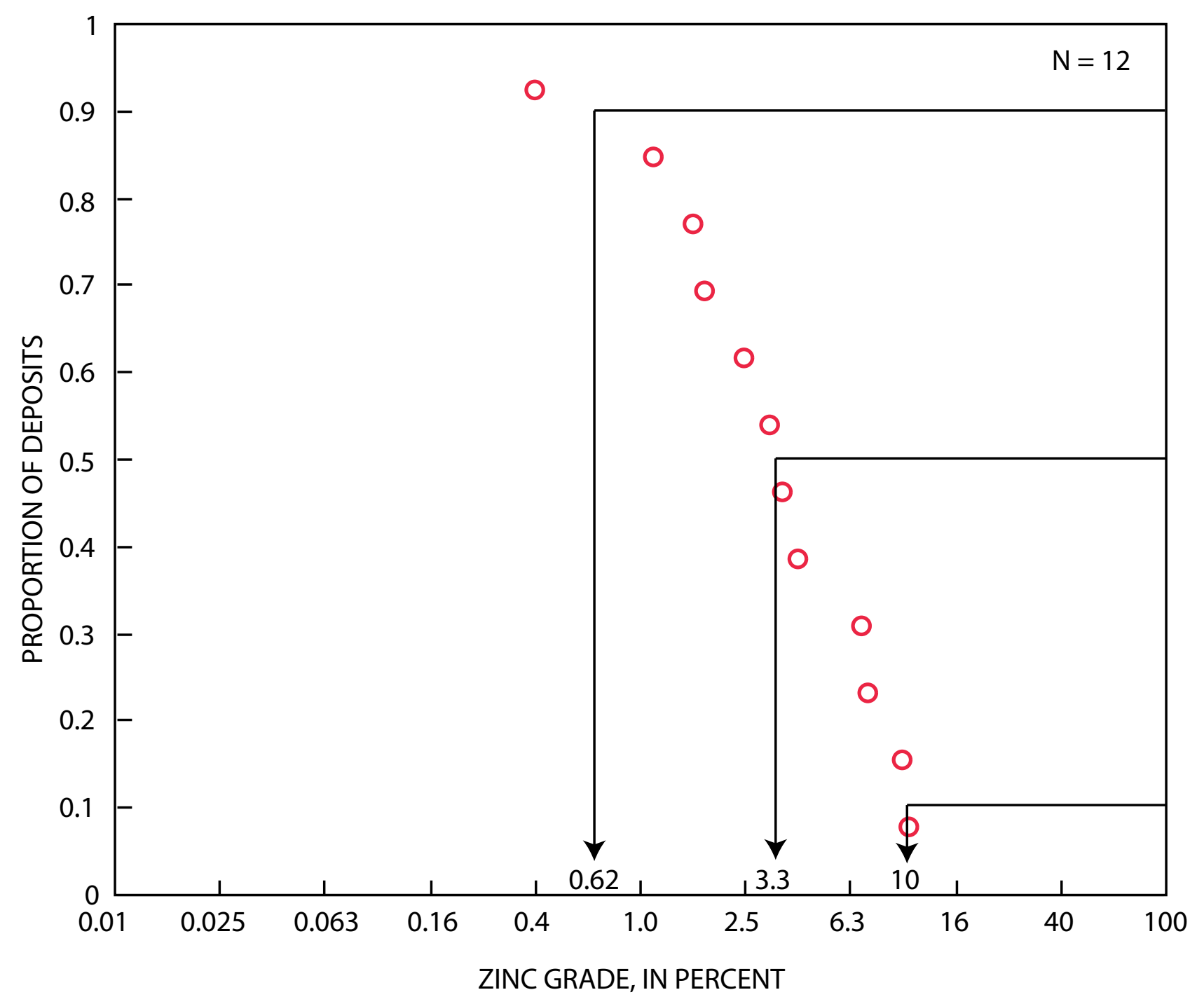

Figure 29. Cumulative frequency of average zinc grades of mixed lithology metamorphosed zinc-lead (MLme) deposits. Each circle represents an individual deposit. Intercepts for the 90th, 50th, and 10th percentiles of the observed distribution are provided 


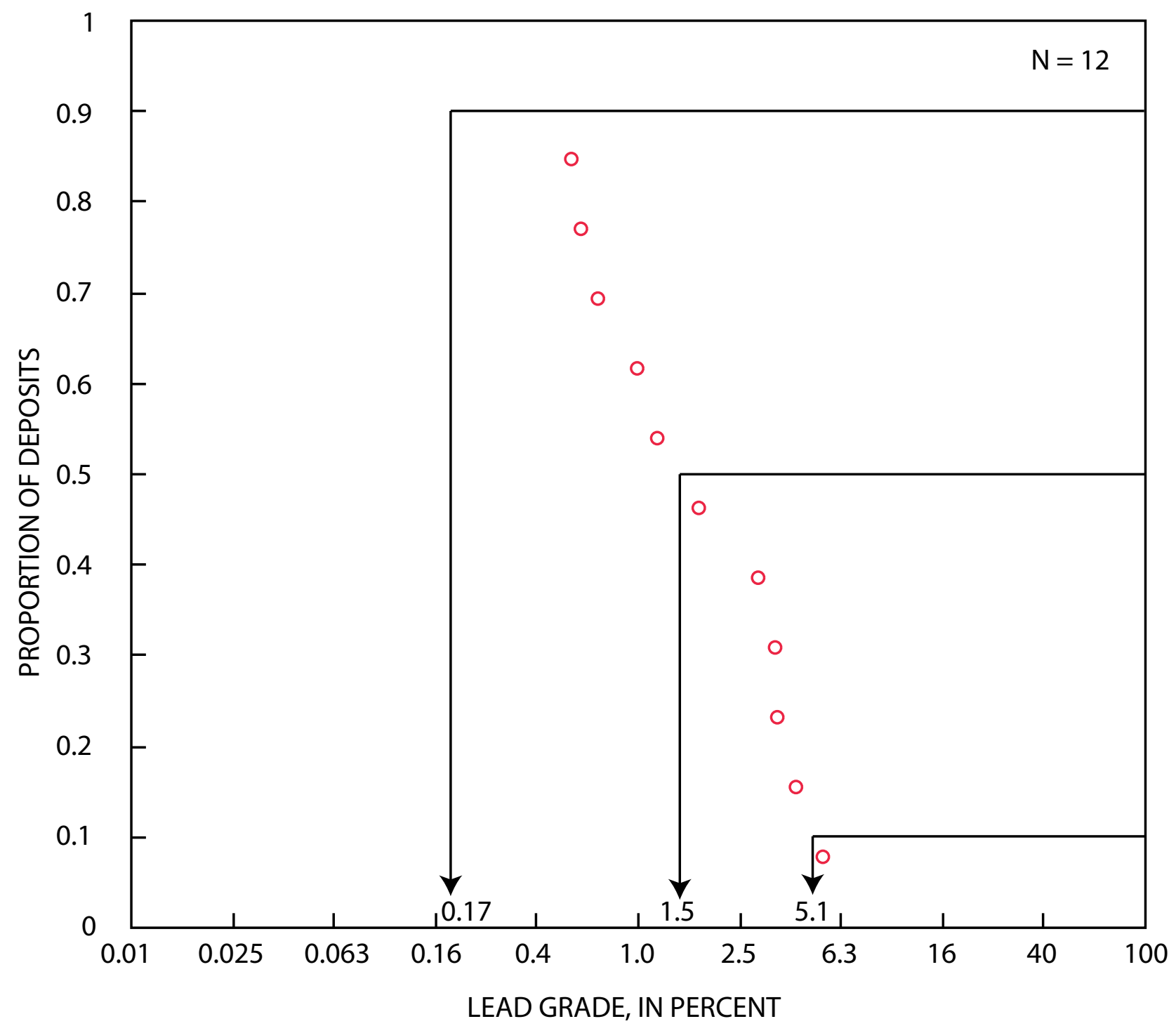

Figure 30. Cumulative frequency of average lead grades of mixed lithology metamorphosed zinc-lead (MLme) deposits. Each circle represents an individual deposit. Intercepts for the 90th, 50th, and 10th percentiles of the observed distribution are provided 


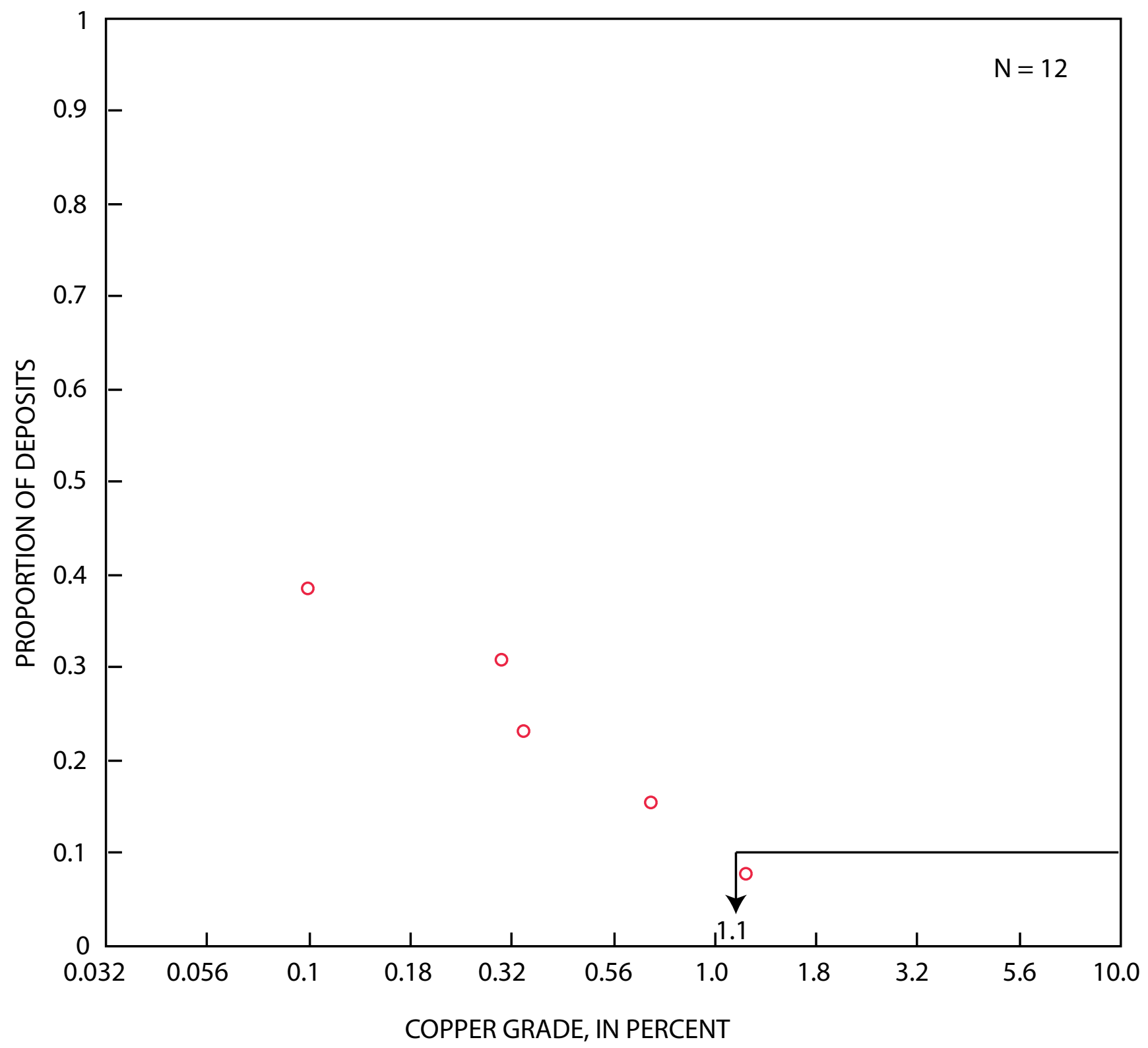

Figure 31. Cumulative frequency of average copper grades of mixed lithology metamorphosed zinc-lead (MLme) deposits. Each circle represents an individual deposit. Intercept for the 10th percentile of the observed distribution is provided 


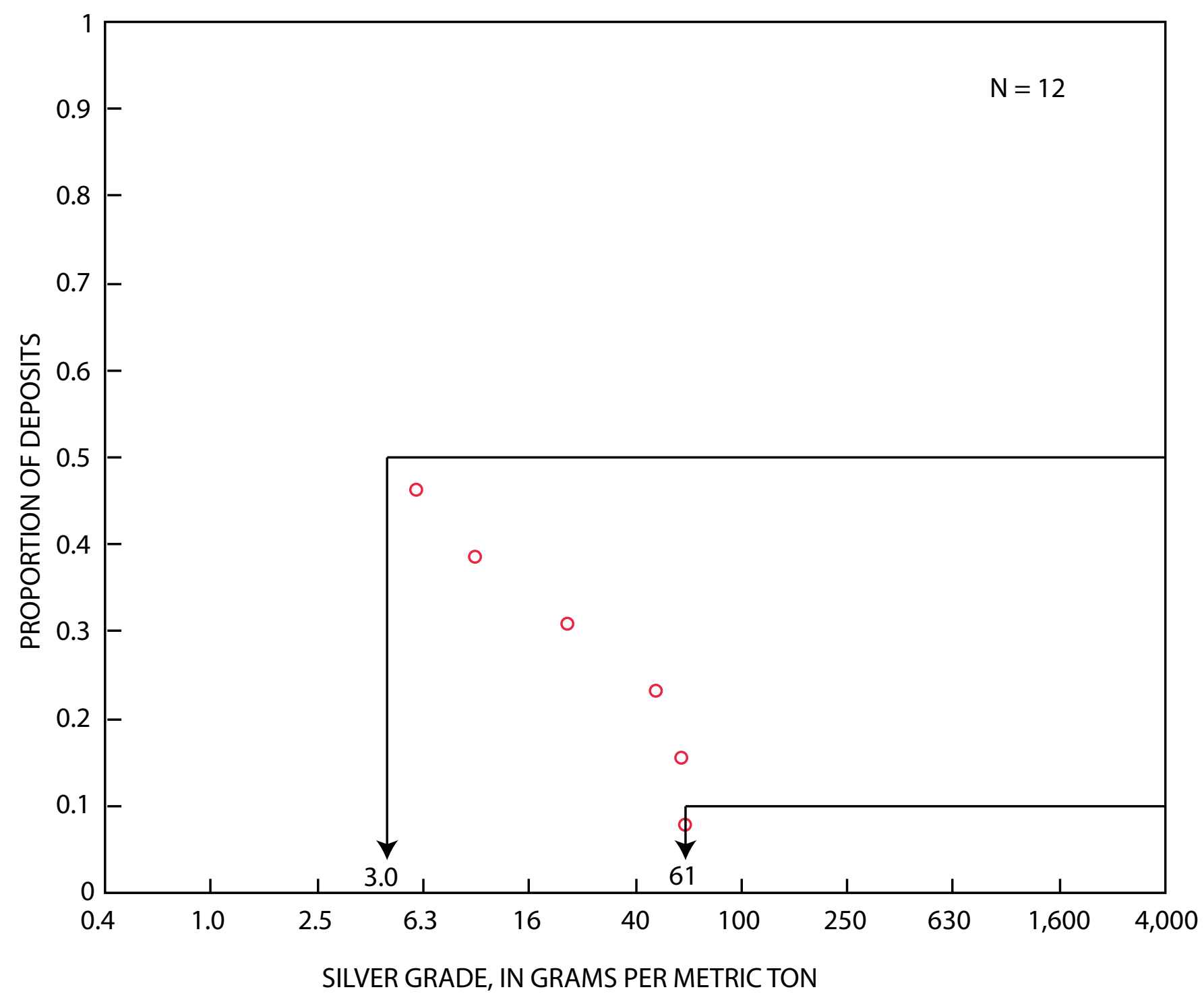

Figure 32. Cumulative frequency of average silver grades of mixed lithology metamorphosed zinc-lead (MLme) deposits. Each circle represents an individual deposit. Intercepts for the 50th and 10th percentiles of the observed distribution are provided 


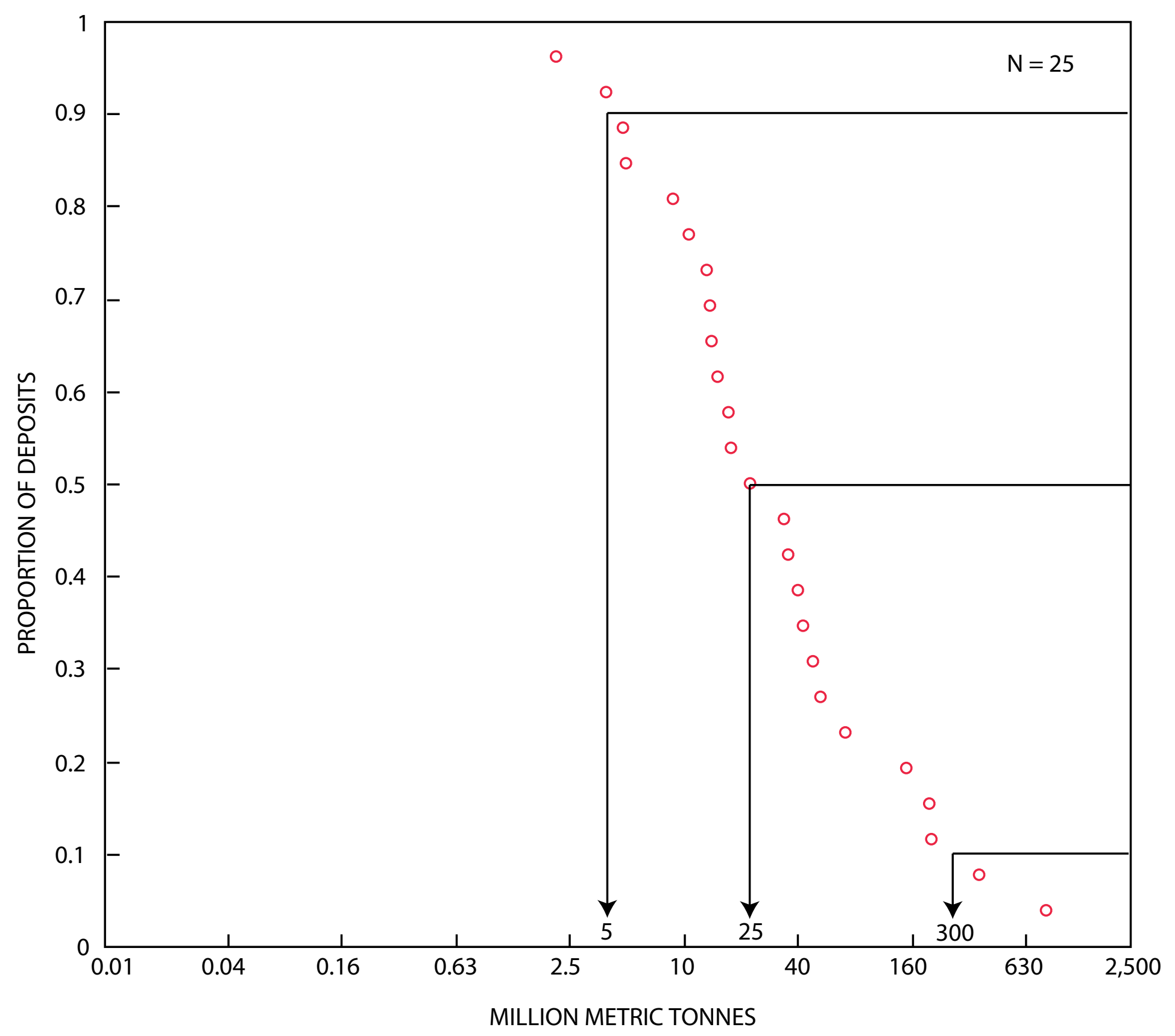

Figure 33 Cumulative frequency of ore tonnage of shale-hosted amagmatic zinc-lead (SHam) deposits. Each circle represents an individual deposit. Intercepts for the 90th, 50th, and 10th percentiles of the observed distribution are provided 


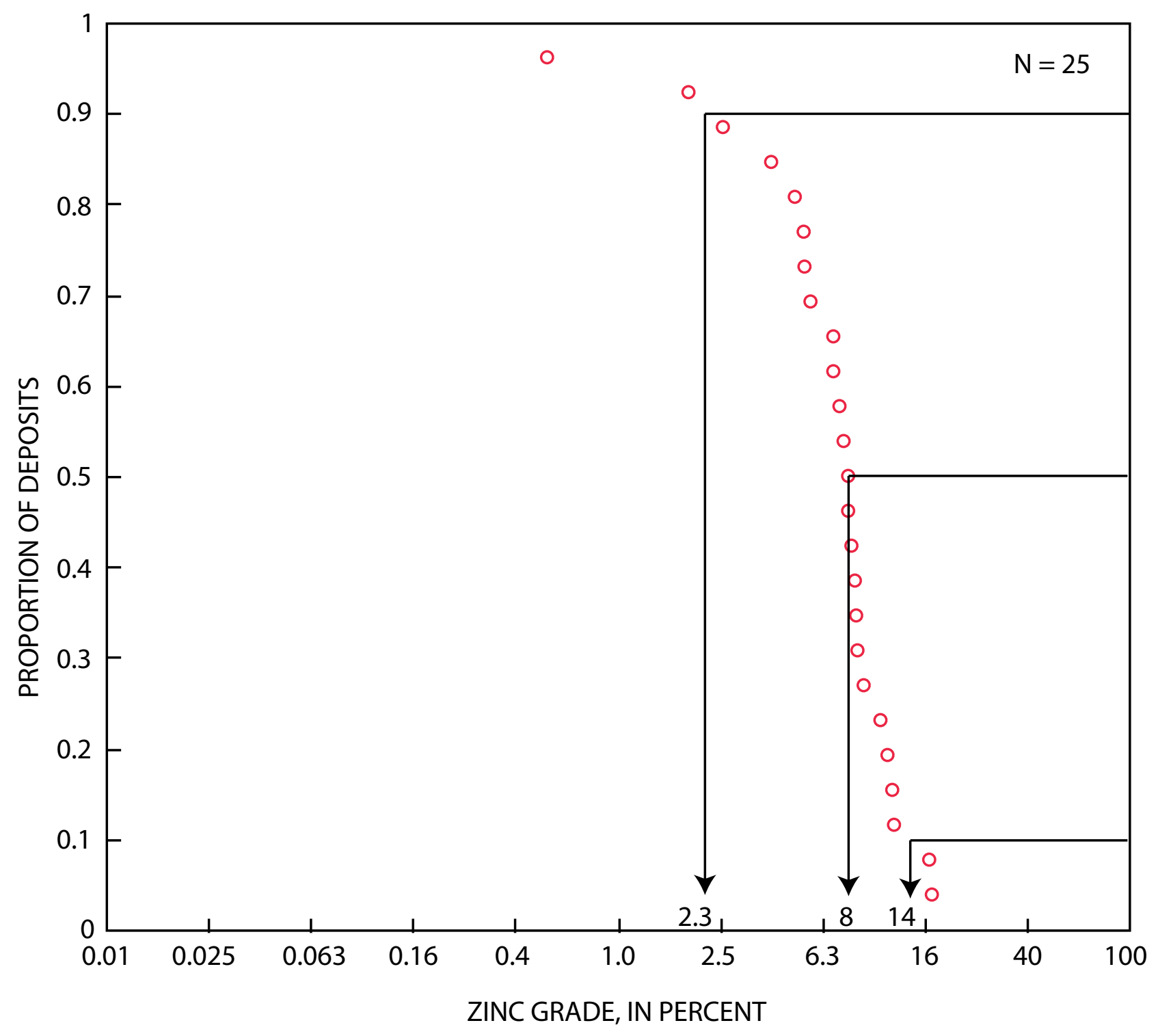

Figure 34 Cumulative frequency of average zinc grades of shale-hosted amagmatic zinc-lead (SHam) deposits. Each circle represents an individual deposit. Intercepts for the 90th, 50th, and 10th percentiles of the observed distribution are provided 


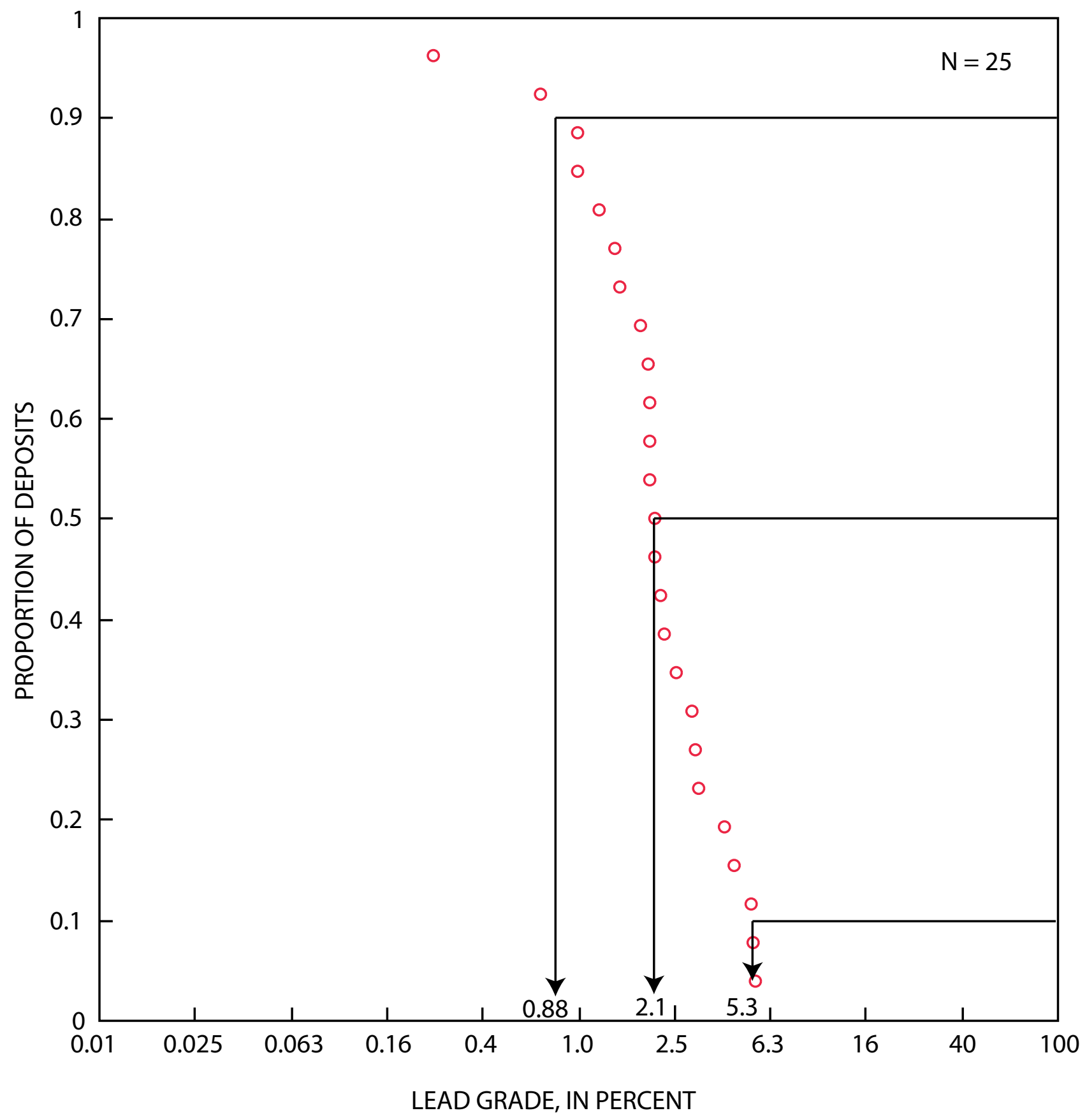

Figure 35 Cumulative frequency of average lead grades of shale-hosted amagmatic zinc-lead (SHam) deposits. Each circle represents an individual deposit. Intercepts for the 90th, 50th, and 10th percentiles of the observed distribution are provided 


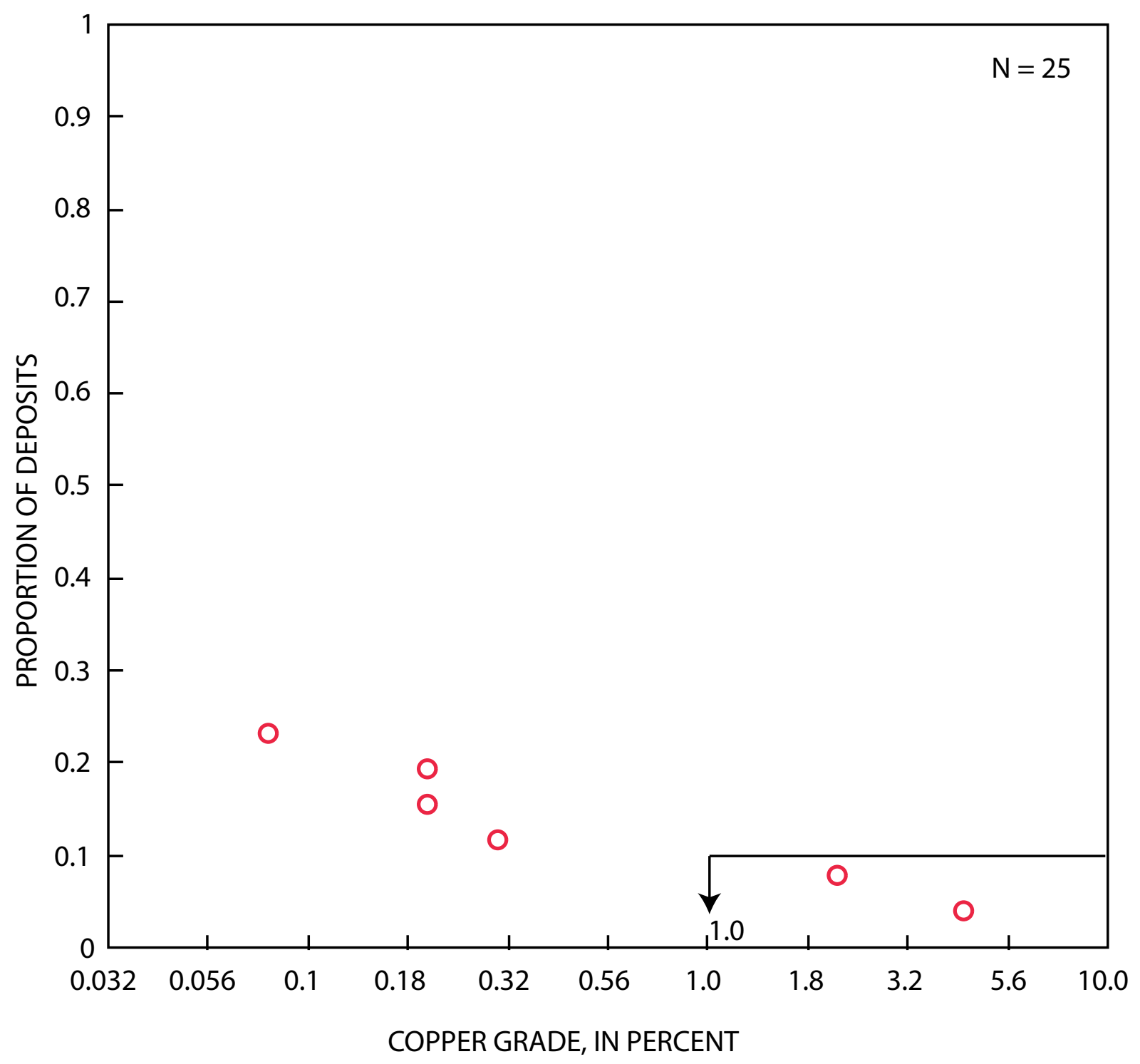

Figure 36 Cumulative frequency of average copper grades of shale-hosted amagmatic zinc-lead (SHam) deposits. Each circle represents an individual deposit. Intercept for the 10th percentile of the observed distribution is provided. 


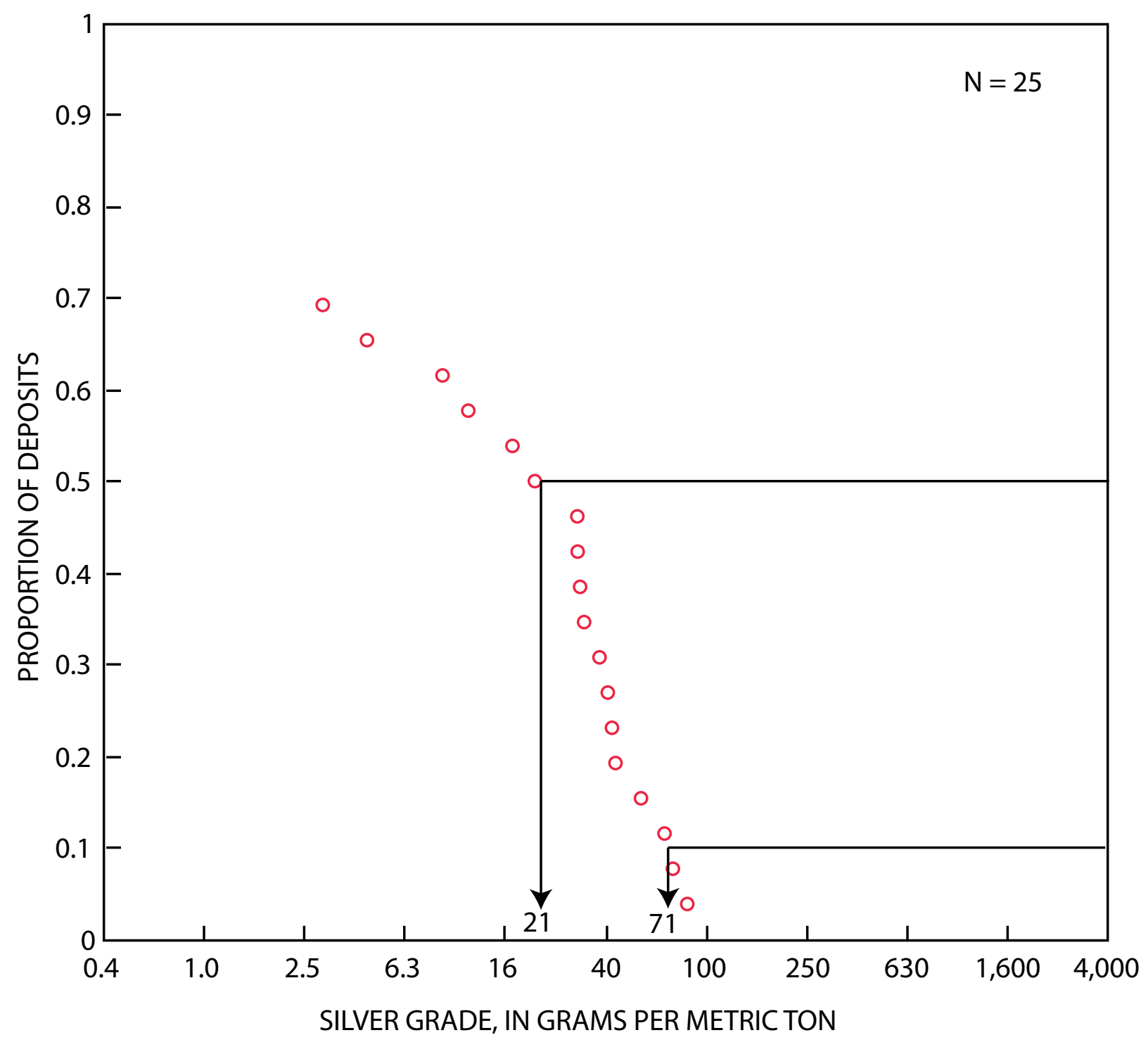

Figure 37 Cumulative frequency of average silver grades of shale-hosted amagmatic zinc-lead (SHam) deposits. Each circle represents an individual deposit. Intercepts for the 50th and 10th percentiles of the observed distribution are provided 


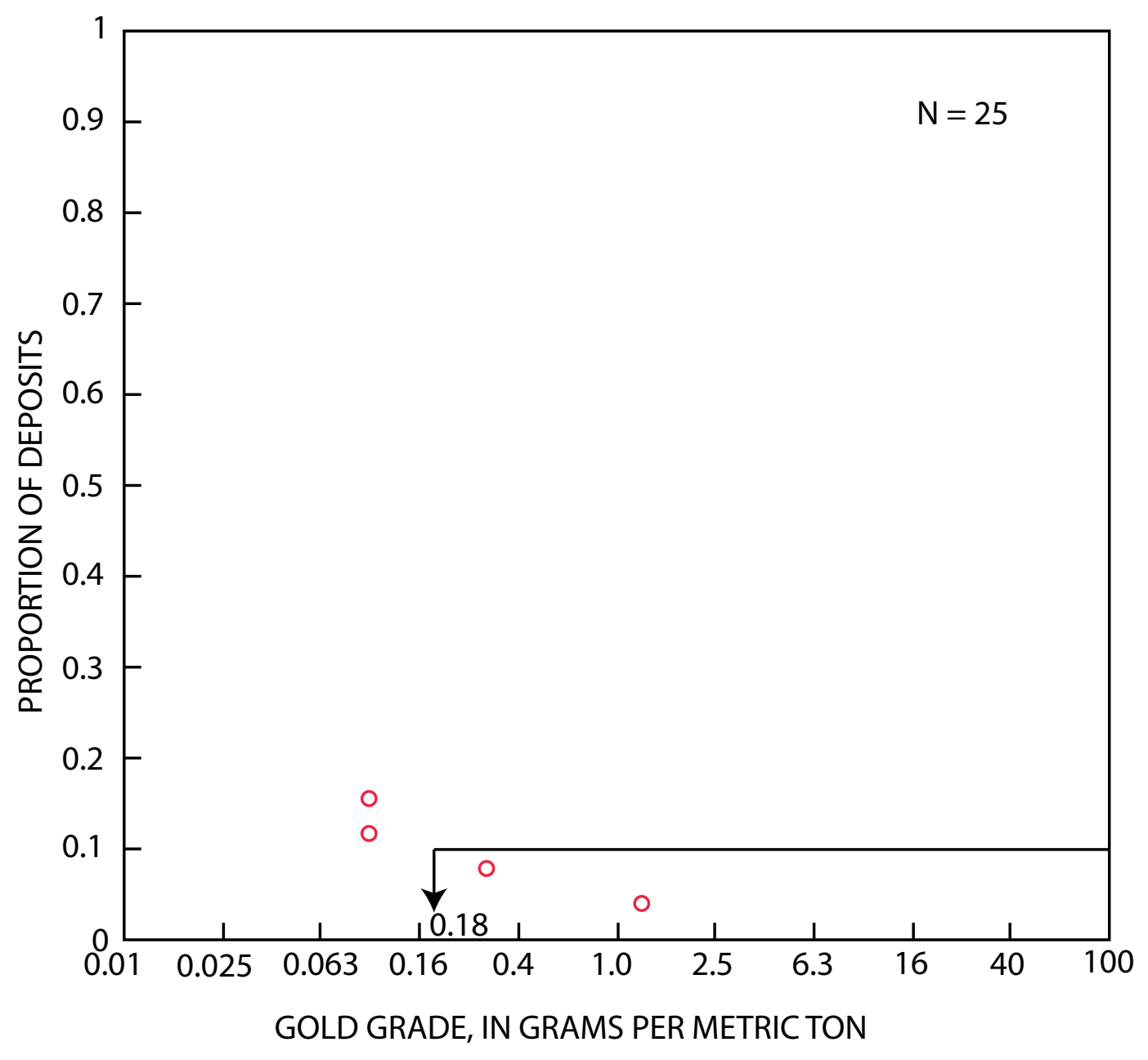

Figure 38 Cumulative frequency of average gold grades of shale-hosted amagmatic zinc-lead (SHam) deposits. Each circle represents an individual deposit. Intercept for the 10th percentile of the observed distribution is provided 


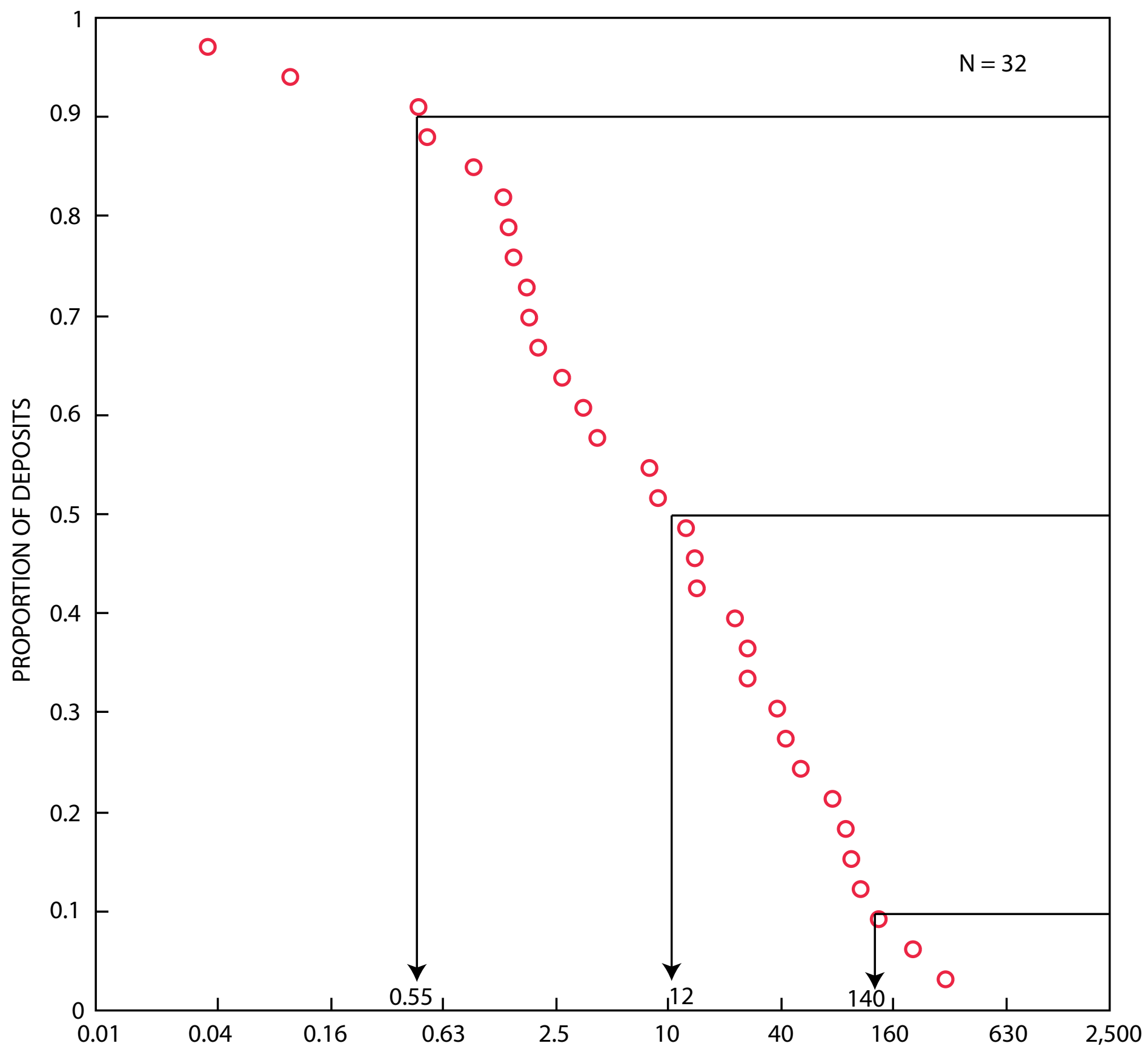

MILLION METRIC TONNES

Figure 39 Cumulative frequency of ore tonnage of shale-hosted igneous-related zinc-lead (SHig) deposits. Each circle represents an individual deposit. Intercepts for the 90th, 50th, and 10th percentiles of the observed distribution are provided 


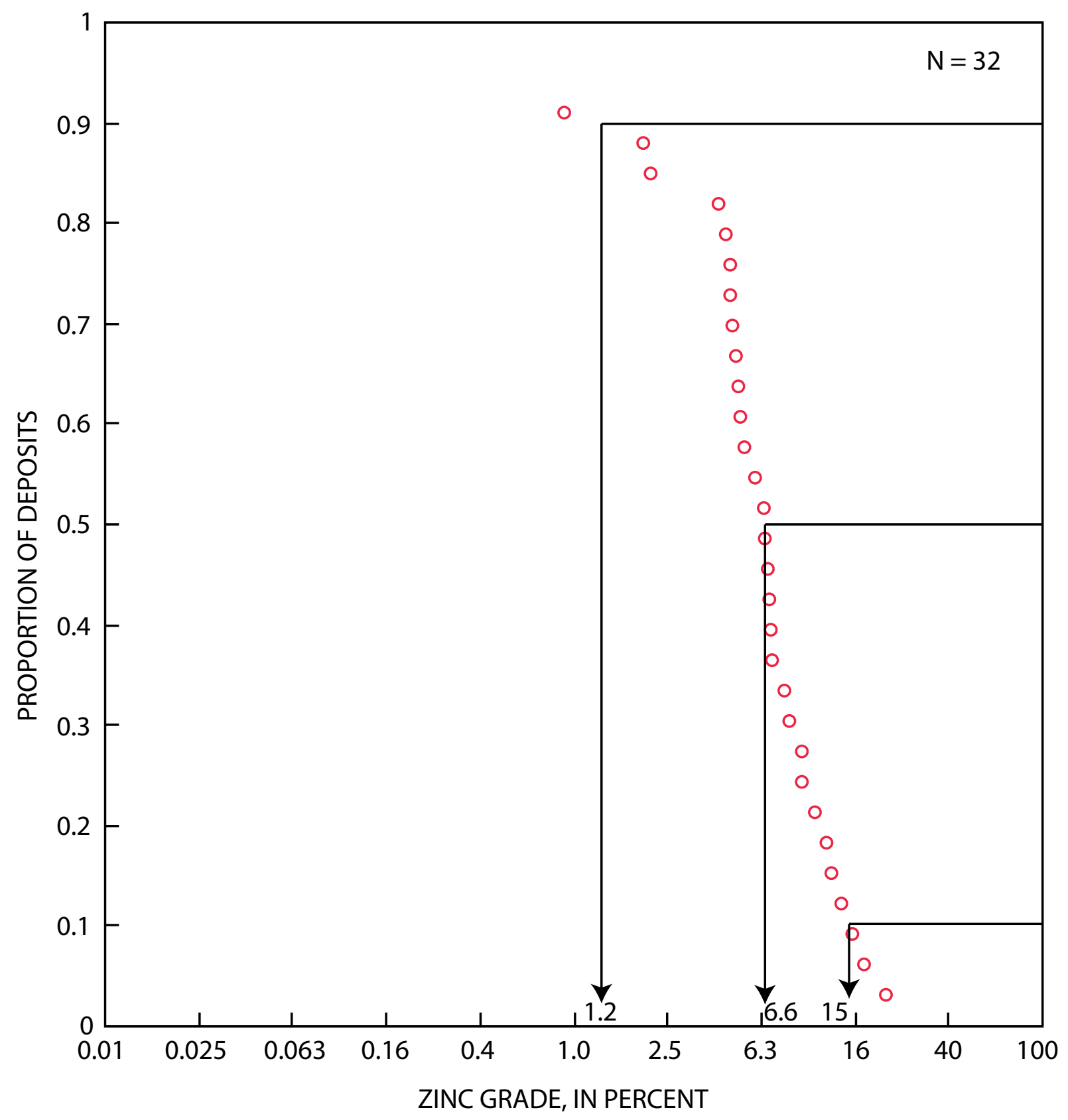

Figure 40 Cumulative frequency of average zinc grades of shale-hosted igneous-related zinc-lead (SHig) deposits. Each circle represents an individual deposit. Intercepts for the 90th, 50th, and 10th percentiles of the observed distribution are provided 


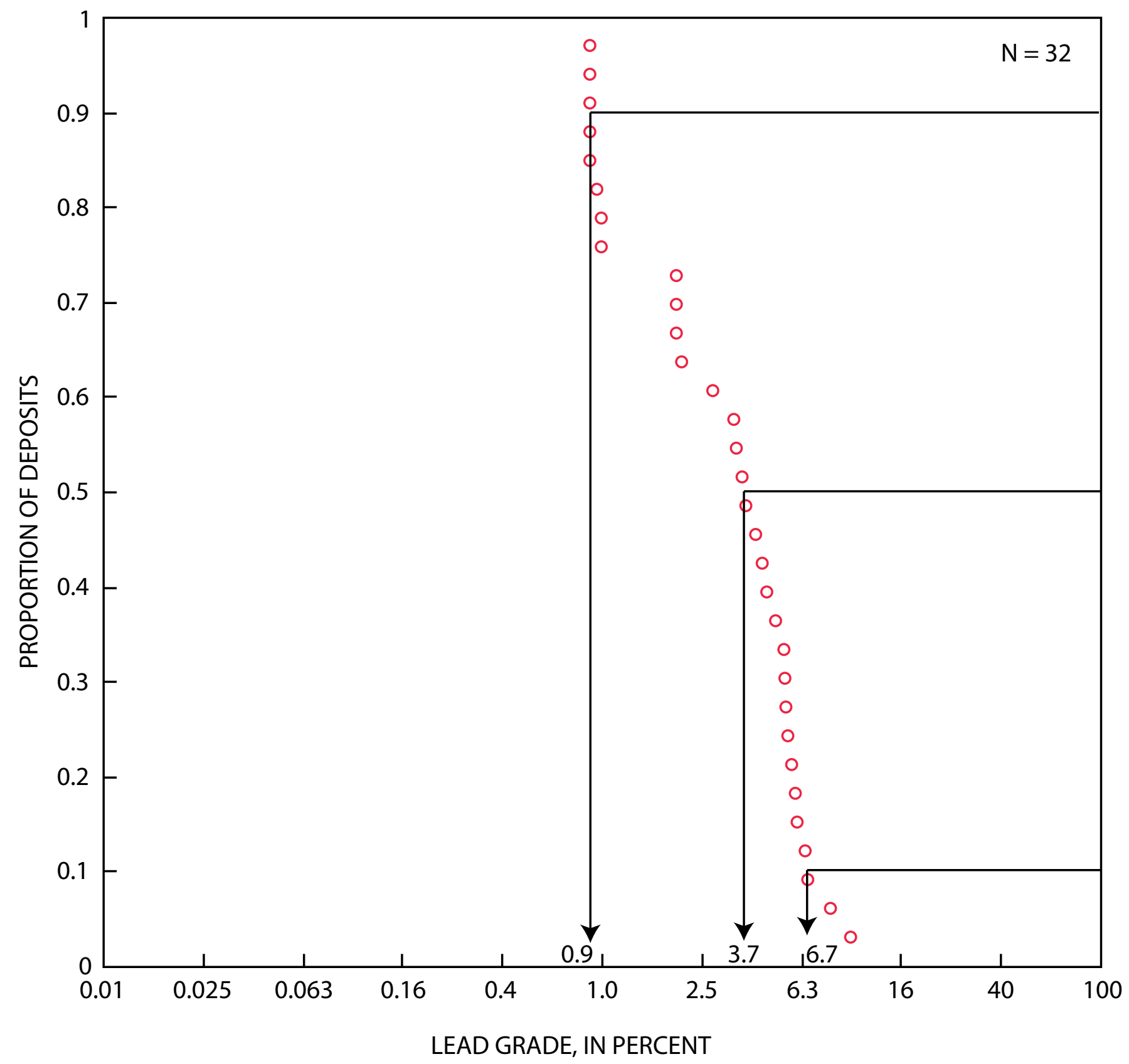

Figure 41 Cumulative frequency of average lead grades of shale-hosted igneous related zinc-lead (SHig) deposits. Each circle represents an individual deposit. Intercepts for the 90th, 50th, and 10th percentiles of the observed distribution are provided 


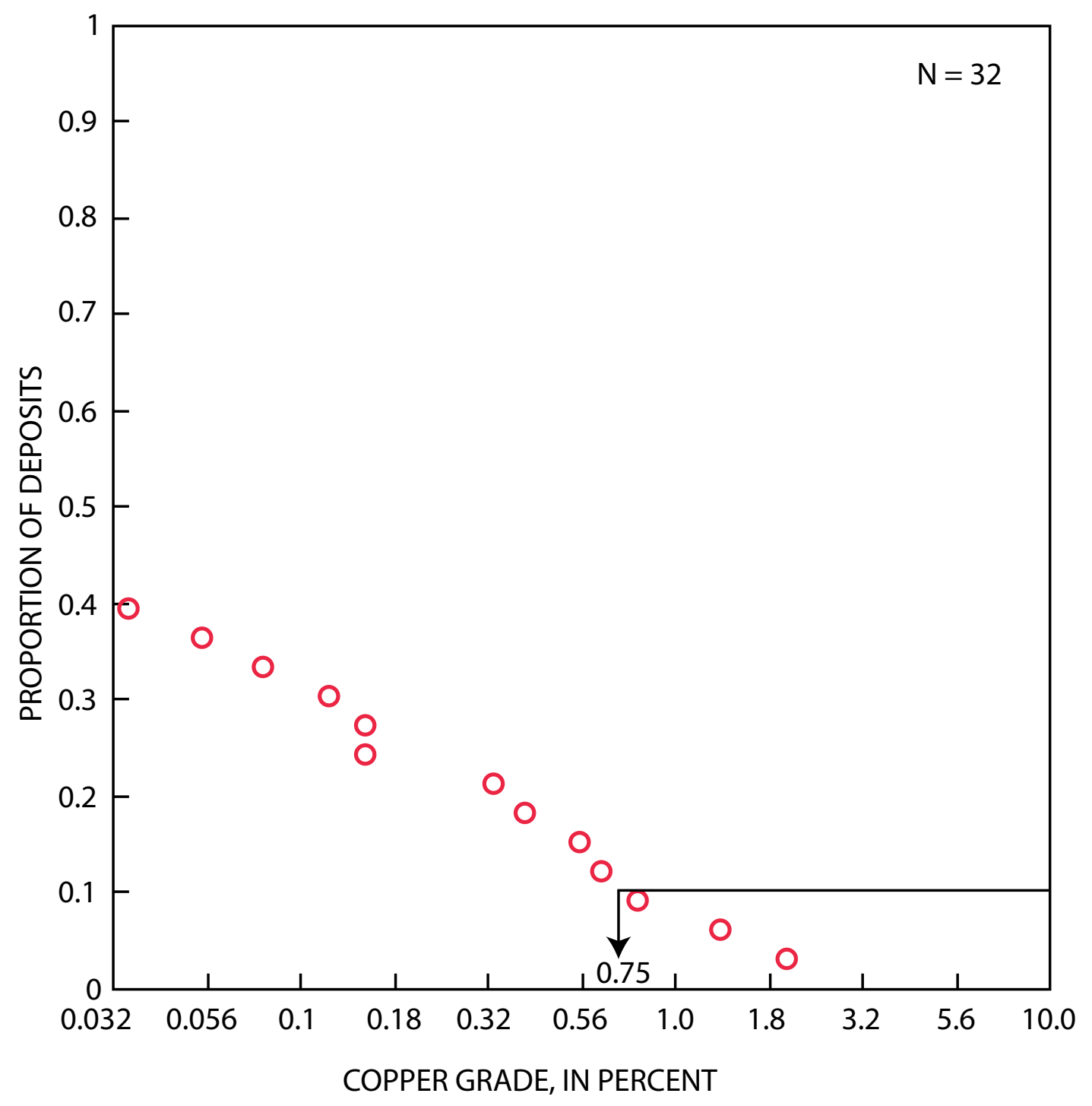

Figure 42 Cumulative frequency of average copper grades of shale-hosted igneous-related zinc-lead (SHig) deposits. Each circle represents an individual deposit. Intercept for the 10th percentile of the observed distribution is provided 


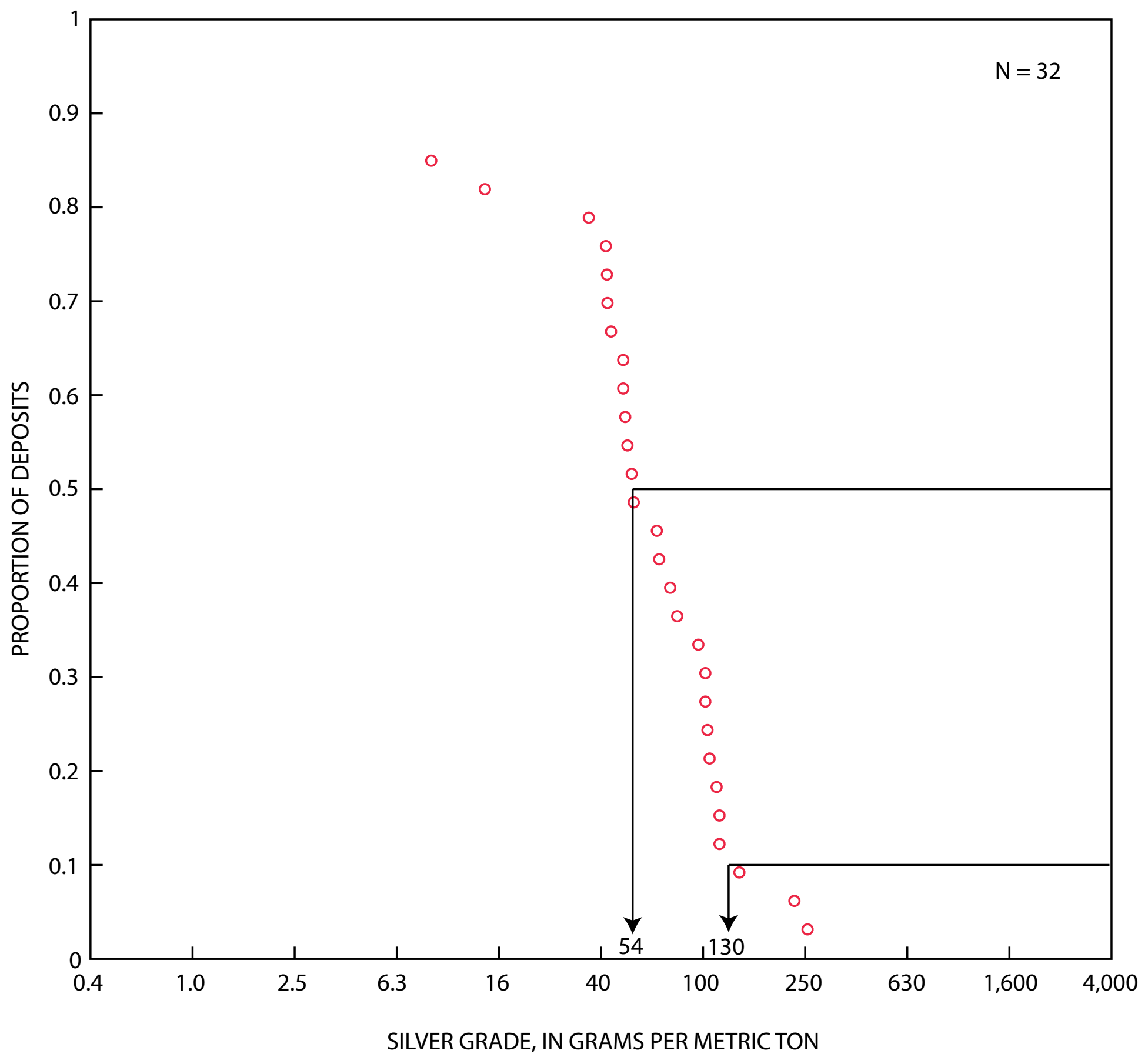

Figure 43 Cumulative frequency of average silver grades of shale-hosted igneous-related zinc-lead (SHig) deposits. Each circle represents an individual deposit. Intercepts for the 50th and 10th percentiles of the observed distribution are provided 


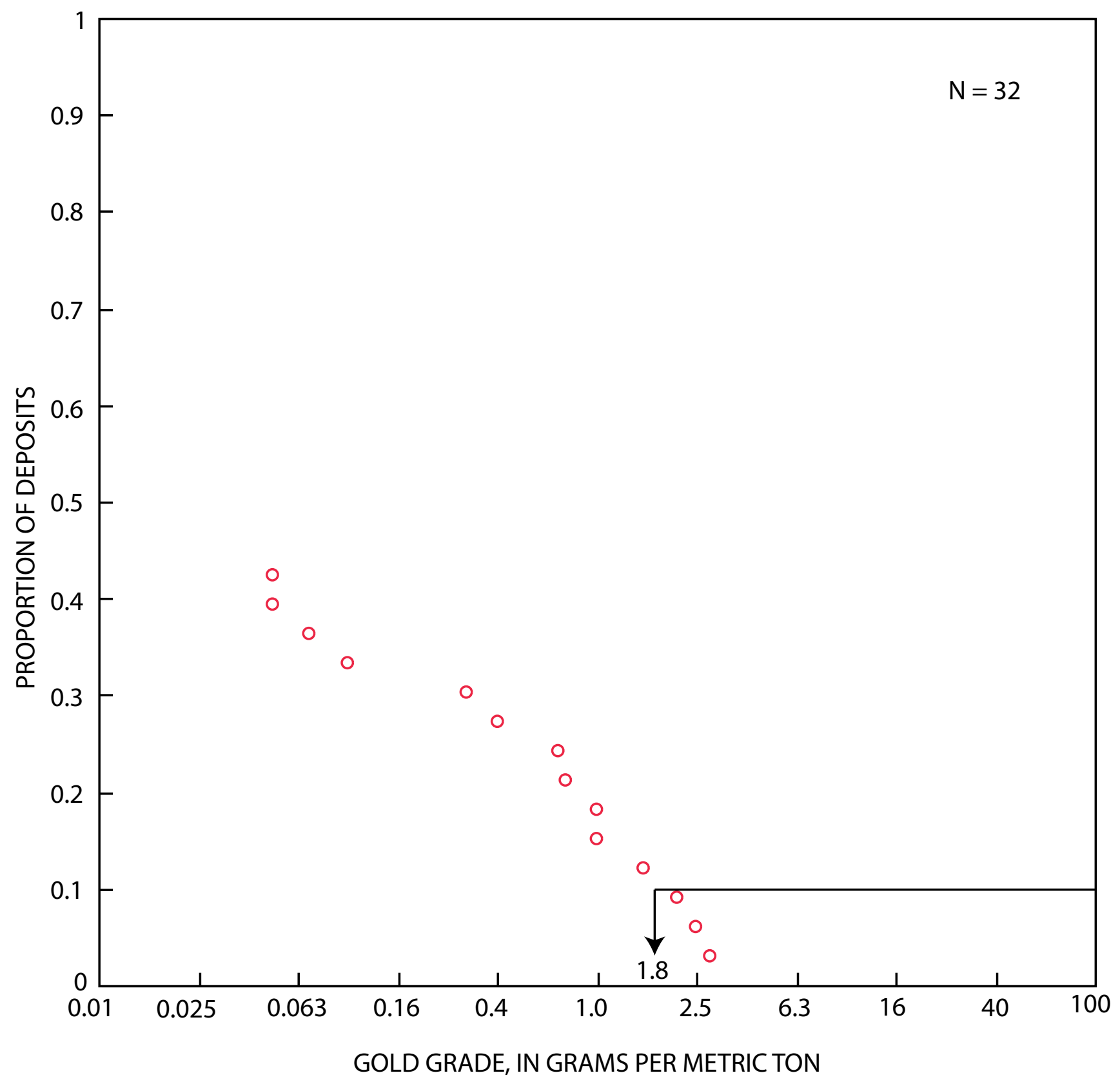

Figure 44 Cumulative frequency of average gold grades of shale-hosted igneous-related zinc-lead (SHig) deposits. Each circle represents an individual deposit. Intercept for the 10th percentile of the observed distribution is provided 


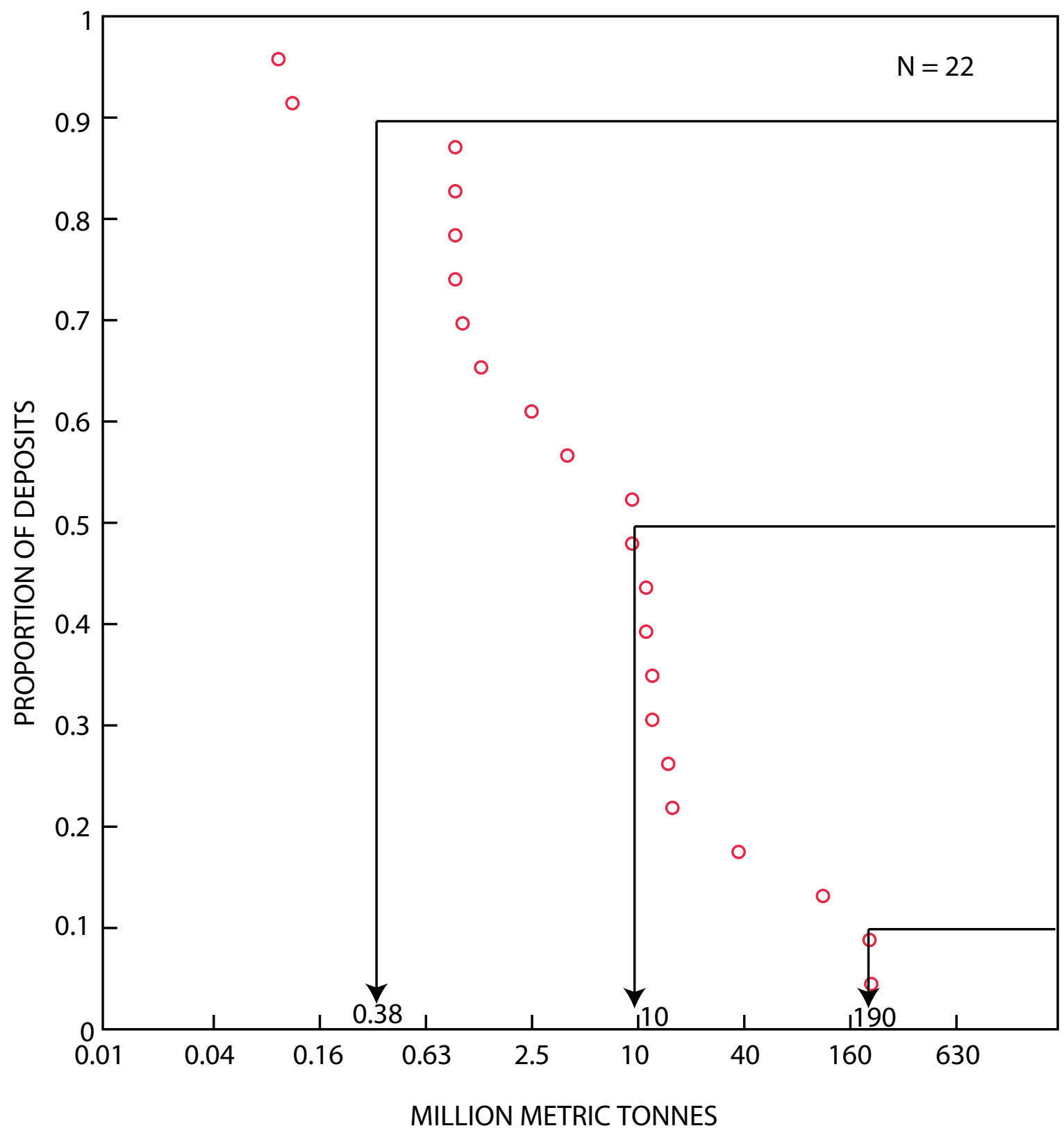

Figure 45 Cumulative frequency of ore tonnage of sandstone-hosted lead deposits. Each circle represents an individual deposit. Intercepts for the 90th, 50th, and 10th percentiles of the observed distribution are provided 


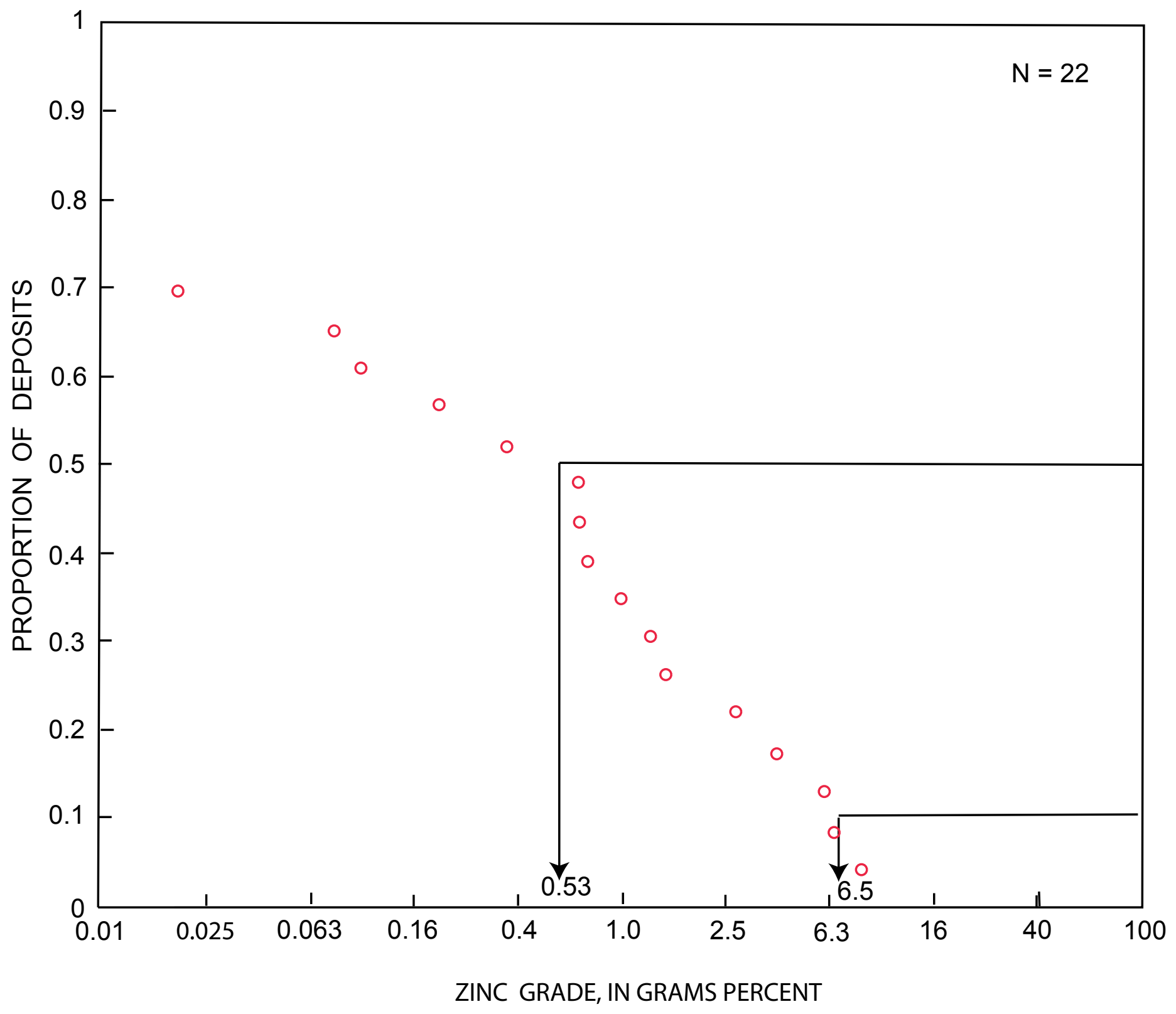

Figure 46 Cumulative frequency of zinc grades of sandstone-hosted zinc-lead (SHig) deposits. Each circle represents an individual deposit. Intercept for the 50th and 10th percentiles of the observed distribution are provided 


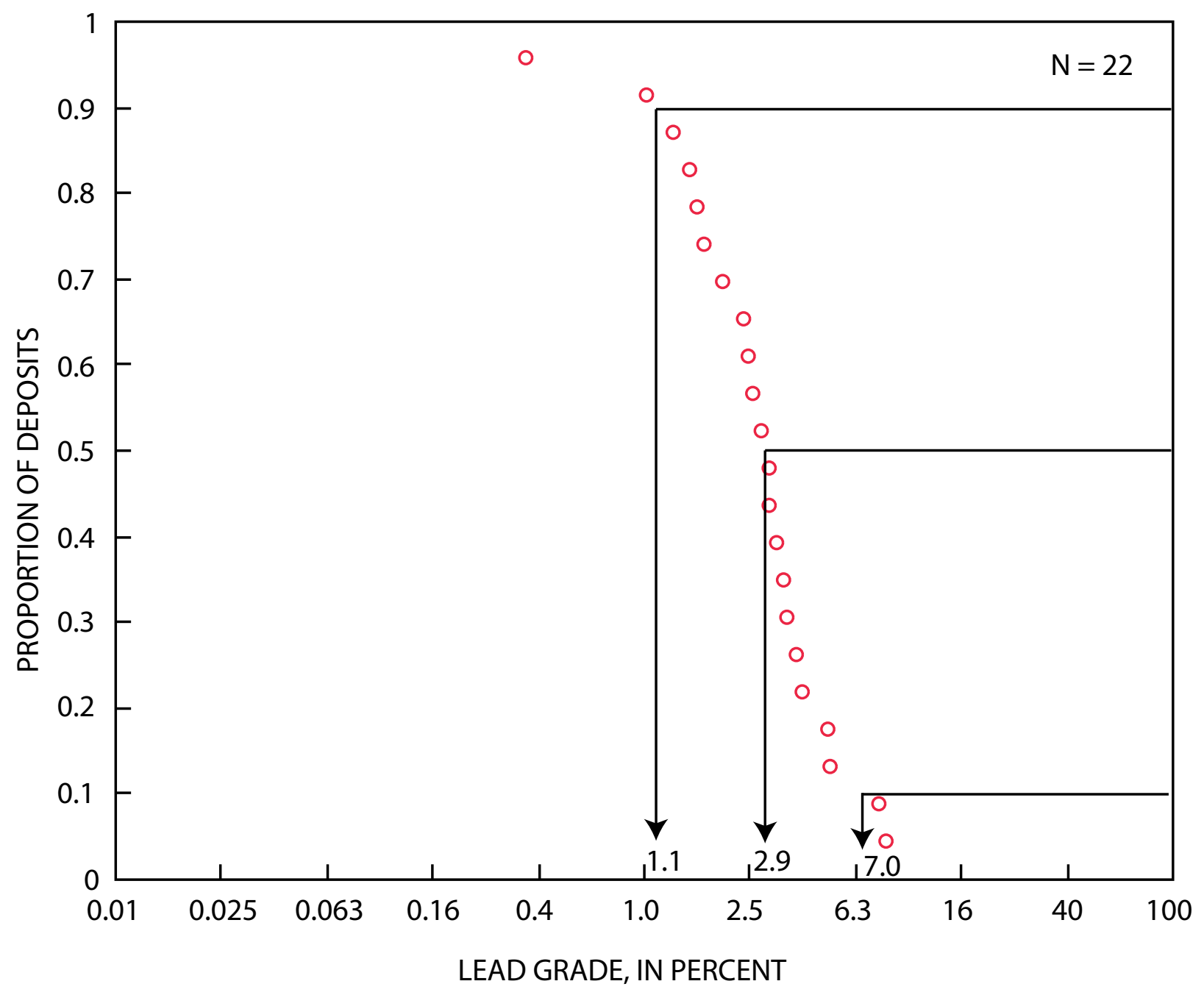

Figure 47 Cumulative frequency of lead grades of sandstone-hosted lead deposits. Each circle represents an individual deposit. Intercepts for the 90th, 50th, and 10th percentiles of the observed distribution are provided 


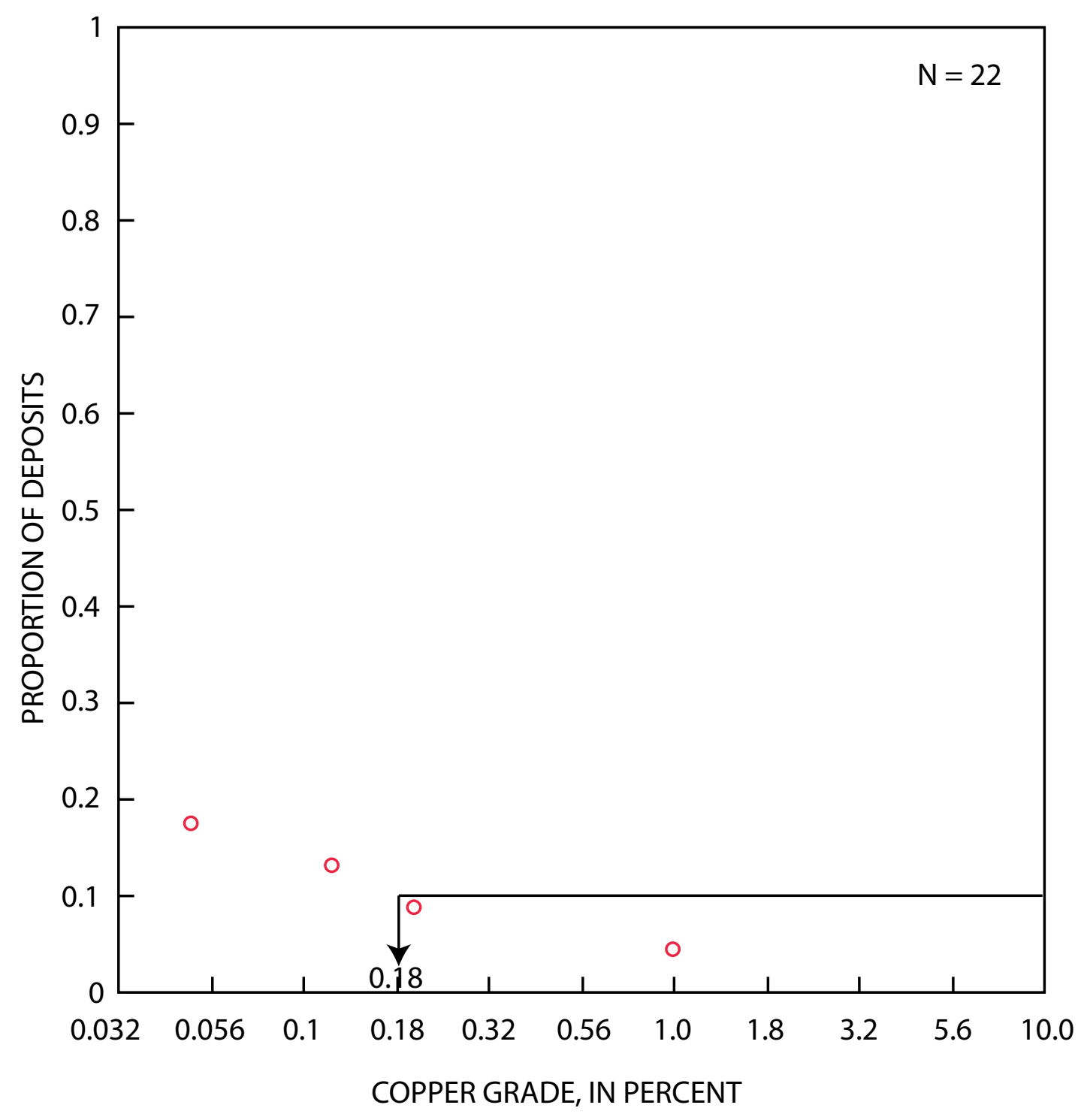

Figure 48 Cumulative frequency of copper grades of sandstone-hosted lead deposits. Each circle represents an individual deposit. Intercept for the 10th percentile of the observed distribution is provided 


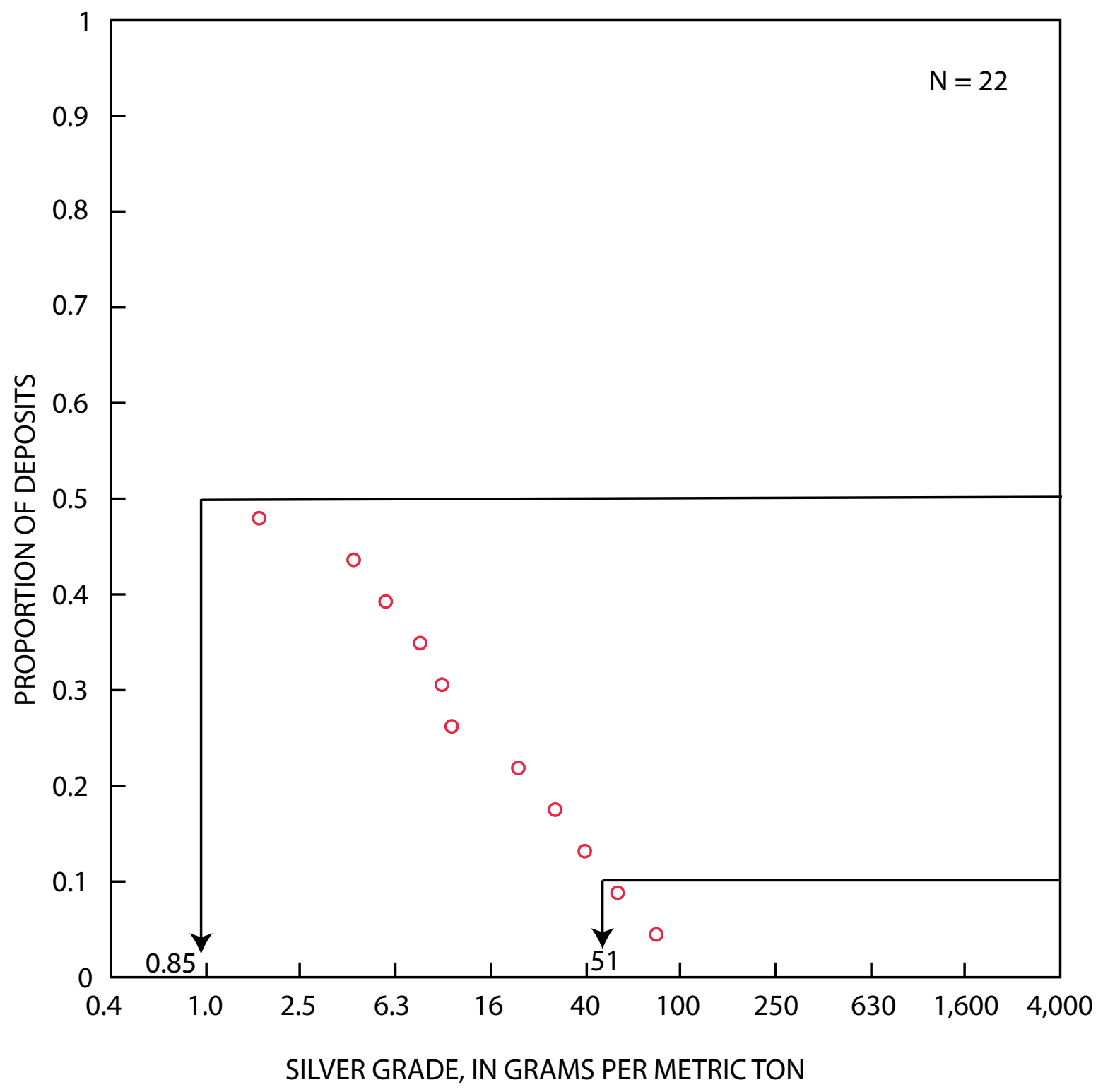

Figure 49 Cumulative frequency of silver grades of sandstone-hosted lead deposits. Each circle represents an individual deposit. Intercepts for the 50th, and 10th percentiles of the observed distribution are provided 